\title{
Cochrane
}

Library

Cochrane Database of Systematic Reviews

\section{Growth factors for angiogenesis in peripheral arterial disease} (Review)

Gorenoi V, Brehm MU, Koch A, Hagen A

Gorenoi V, Brehm MU, Koch A, Hagen A.

Growth factors for angiogenesis in peripheral arterial disease.

Cochrane Database of Systematic Reviews 2017, Issue 6. Art. No.: CD011741.

DOI: 10.1002/14651858.CD011741.pub2.

www.cochranelibrary.com 
TABLE OF CONTENTS

HEADER 1

ABSTRACT

PLAIN LANGUAGE SUMMARY

SUMMARY OF FINDINGS

BACKGROUND

OBJECTIVES

METHODS

RESULTS

Figure 1.

Figure 2.

DISCUSSION

AUTHORS' CONCLUSIONS

ACKNOWLEDGEMENTS

REFERENCES

CHARACTERISTICS OF STUDIES

DATA AND ANALYSES

Analysis 1.1. Comparison 1 Growth factors versus placebo (or no therapy), Outcome 1 Limb amputation (major or not specified; at 1 year).

Analysis 1.2. Comparison 1 Growth factors versus placebo (or no therapy), Outcome 2 Limb amputation (major or not specified; last data to 2 years).

Analysis 1.3. Comparison 1 Growth factors versus placebo (or no therapy), Outcome 3 Limb amputation (any or not specified; at 1 year).

Analysis 1.4. Comparison 1 Growth factors versus placebo (or no therapy), Outcome 4 Limb amputation (any or not specified; last data to 2 years).

Analysis 1.5. Comparison 1 Growth factors versus placebo (or no therapy), Outcome 5 Death (of any cause; at 1 year). ........... Analysis 1.6. Comparison 1 Growth factors versus placebo (or no therapy), Outcome 6 Death (from any cause; last data to 2 years).

Analysis 1.7. Comparison 1 Growth factors versus placebo (or no therapy), Outcome 7 Adverse events (serious; only aggregate data, up to 2 years).

Analysis 1.8. Comparison 1 Growth factors versus placebo (or no therapy), Outcome 8 Adverse events (serious; incl. data for single events, up to 2 years).

Analysis 1.9. Comparison 1 Growth factors versus placebo (or no therapy), Outcome 9 Adverse events (any; only aggregated data, up to 2 years).

Analysis 1.10. Comparison 1 Growth factors versus placebo (or no therapy), Outcome 10 Adverse events (any; incl. data for single events, up to 2 years).

Analysis 1.11. Comparison 1 Growth factors versus placebo (or no therapy), Outcome 11 Walking ability (change in peak walking time [min]; last data to 6 months).

Analysis 1.12. Comparison 1 Growth factors versus placebo (or no therapy), Outcome 12 Walking ability (change in claudication onset time [min]; last data to 6 months).

Analysis 1.13. Comparison 1 Growth factors versus placebo (or no therapy), Outcome 13 Haemodynamic measures (change in $\mathrm{ABI}$; last data to 6 months).

Analysis 1.14. Comparison 1 Growth factors versus placebo (or no therapy), Outcome 14 Haemodynamic measures (change in TBI; last data to 6 months).

Analysis 1.15. Comparison 1 Growth factors versus placebo (or no therapy), Outcome 15 Ulceration (complete ulcer healing; last data to 1 year).

Analysis 1.16. Comparison 1 Growth factors versus placebo (or no therapy), Outcome 16 Ulceration (improvement in ulcer size; last data to 1 year).

Analysis 1.17. Comparison 1 Growth factors versus placebo (or no therapy), Outcome 17 Rest pain (change on $10 \mathrm{~cm}$ VAS; last data to1 year).

Analysis 1.18. Comparison 1 Growth factors versus placebo (or no therapy), Outcome 18 Rest pain (improvement; last data to 1 year). 
[Intervention Review]

\section{Growth factors for angiogenesis in peripheral arterial disease}

Vitali Gorenoi ${ }^{1}$, Michael U Brehm², Armin Koch ${ }^{3}$, Anja Hagen ${ }^{1}$

1Evidence based Medicine \& Health Technology Assessment Working Group, Institute for Epidemiology, Social Medicine and Health Systems Research, Hannover Medical School, Hannover, Germany. 2Department for Cardiology and Angiology, Hannover Medical School, Hannover, Germany. ${ }^{3}$ Institute for Biometry, Hannover Medical School, Hannover, Germany

Contact address: Vitali Gorenoi, Evidence based Medicine \& Health Technology Assessment Working Group, Institute for Epidemiology, Social Medicine and Health Systems Research, Hannover Medical School, Carl-Neuberg-Str. 1, Hannover, 30625, Germany. gorenoi.vitali@mh-hannover.de.

Editorial group: Cochrane Vascular Group.

Publication status and date: New, published in Issue 6, 2017.

Citation: Gorenoi V, Brehm MU, Koch A, Hagen A. Growth factors for angiogenesis in peripheral arterial disease. Cochrane Database of Systematic Reviews 2017, Issue 6. Art. No.: CD011741. DOI: 10.1002/14651858.CD011741.pub2.

Copyright ( 2017 The Cochrane Collaboration. Published by John Wiley \& Sons, Ltd.

\section{A B S T R A C T}

\section{Background}

Peripheral artery disease (PAD) is associated with a high clinical and socioeconomic burden. Treatments to alleviate the symptoms of PAD and decrease the risks of amputation and death are a high societal priority. A number of growth factors have shown a potential to stimulate angiogenesis. Growth factors delivered directly (as recombinant proteins), or indirectly (e.g. by viral vectors or DNA plasmids encoding these factors), have emerged as a promising strategy to treat patients with PAD.

\section{Objectives}

To assess the effects of growth factors that promote angiogenesis for treating people with PAD of the lower extremities.

\section{Search methods}

The Cochrane Vascular Information Specialist searched the Specialised Register (June 2016) and CENTRAL (2016, Issue 5). We searched trial registries for details of ongoing or unpublished studies. We also checked the reference lists of relevant publications and, if necessary, tried to contact the trialists for details of the studies.

\section{Selection criteria}

We included randomised controlled trials comparing growth factors (delivered directly or indirectly) with no intervention, placebo or any other intervention not based on the growth factor's action in patients with PAD of the lower extremities. The primary outcomes were limb amputation, death and adverse events. The secondary outcomes comprised walking ability, haemodynamic measures, ulceration and rest pain.

\section{Data collection and analysis}

Two review authors independently selected trials and assessed the risk of bias. We used outcomes of the studies at low risk of bias for the main analysis and of all studies in the sensitivity analyses. We calculated odds ratios (OR) for dichotomous outcomes and mean differences for continuous outcomes with $95 \%$ confidence intervals $(\mathrm{CI})$. We evaluated statistical heterogeneity using the $\mathrm{I}^{2}$ statistic and Cochrane's $\mathrm{Q}$ test. We conducted meta-analysis for the overall effect and for each growth factor as a subgroup analysis using OR in a fixed-effect model. We evaluated the robustness of the results in a sensitivity analysis using risk ratio (RR) and/or a random-effects model. We also assessed the quality of the evidence for each outcome. 


\section{Main results}

We included 20 trials in the review and used 14 studies (on approximately 1400 participants) with published results in the analyses. Six published studies compared fibroblast growth factors (FGF), four studies hepatocyte growth factors (HGF) and another four studies vascular endothelial growth factors (VEGF), versus placebo or no therapy. Six of these studies exclusively or mainly investigated participants with intermittent claudication and eight studies exclusively participants with critical limb ischaemia. Follow-up generally ranged from three months to one year. Two small studies provided some data at 2 years and one of them also at 10 years.

The direction and size of effects for growth factors on major limb amputations (OR 0.99, 95\% $\mathrm{Cl} 0.71$ to $1.38 ; 10 \mathrm{studies,} \mathrm{N}=1075$ ) and death (OR $0.99,95 \% \mathrm{Cl} 0.69$ to $1.41 ; 12$ studies, $\mathrm{N}=1371$ ) at up to two years are uncertain. The quality of the evidence is low due to risk of bias and imprecision (at one year, moderate-quality evidence due to imprecision). However, growth factors may decrease the rate of any limb amputations (OR $0.56,95 \% \mathrm{Cl} 0.31$ to $0.99 ; 6$ studies, $\mathrm{N}=415$ ). The quality of the evidence is low due to risk of bias and selective reporting.

The direction and size of effects for growth factors on serious adverse events (OR $1.09,95 \% \mathrm{Cl} 0.79$ to $1.50 ; 13$ studies, $\mathrm{N}=1411$ ) and on any adverse events (OR 1.10,95\% $\mathrm{Cl} 0.73$ to $1.64 ; 4$ studies, $\mathrm{N}=709$ ) at up to two years are also uncertain. The quality of the evidence is low due to risk of bias and imprecision (for serious adverse events at one year, moderate-quality evidence due to imprecision).

Growth factors may improve haemodynamic measures (low-quality evidence), ulceration (very low-quality evidence) and rest pain (very low-quality evidence) up to one year, but they have little or no effect on walking ability (low-quality evidence). We did not identify any relevant differences in effects between growth factors (FGF, HGF and VEGF).

\section{Authors' conclusions}

The results of this review do not support the use of therapy with the growth factors FGF, HGF or VEGF in people with PAD of the lower extremities to prevent death or major limb amputation or to improve walking ability. However, the use of these growth factors may improve haemodynamic measures and decrease the rate of any limb amputations (probably due to preventing minor amputations) with an uncertain effect on adverse events; an improvement of ulceration and rest pain is very uncertain. New trials at low risk of bias are needed to generate evidence with more certainty.

\section{PLAIN LANGUAGE SUMMARY}

\section{Treating people with reduced blood supply to the legs with substances stimulating new vessel formation (growth factors)}

\section{Background and review question}

Different diseases, such as atherosclerosis, can cause reduced blood supply to the legs. Depending on the disease severity this may be associated with symptoms such as leg pain when walking or resting, ulceration (open sores) and gangrene of the leg. Reduced blood supply to the legs affects $3 \%$ to $10 \%$ of all people and $15 \%$ to $20 \%$ of people over 70 years of age. It is a major cause of decreased mobility and quality of life and of increased risks for amputation or death.

The treatment strategy generally comprises behavioural changes (e.g. smoking cessation, exercise and diet), drugs (e.g. antiplatelets, statins) and catheter-based or surgical interventions. However, for some patients the only option is leg amputation.

Some substances naturally produced in the body, called growth factors, can stimulate new vessel formation. Nowadays, these substances are laboratory produced with the attempt to treat people with reduced blood supply to the legs. Therefore, we evaluated the evidence from clinical studies on the effects of growth factors in those people.

\section{Key results and implications}

We identified 20 studies and analysed the results of 14 published studies involving approximately 1400 patients and assessing three types of growth factors (evidence current to June 2016).

Our review shows that the effects of growth factors on the most important clinical parameters comprising limb amputations above the ankle, death and adverse events are uncertain (low-quality evidence up to two years, although moderate-quality evidence for one year). However, the rate of all limb amputations may decrease (low-quality evidence). In addition, growth factors may improve parameters of blood flow (low-quality evidence), ulceration (very low-quality evidence) and rest pain (very low-quality evidence) at up to one year, but have little or no effect on walking ability (low-quality evidence). We downgraded the quality of evidence mostly due to low statistical power and poor study quality. We did not identify any relevant differences in effects between growth factors.

This review does not support growth factor therapy in people with reduced blood supply to the legs to prevent limb amputations above the ankle or death or to improve walking ability. However, using growth factors may improve parameters of blood flow and prevent limb amputations below the ankle with an uncertain effect on adverse events; an improvement of ulceration and rest pain is very uncertain. New high-quality studies are needed to generate evidence with more certainty. 
SUMMARY OF FINDINGS

Summary of findings for the main comparison. Growth factors versus placebo or no therapy for the treatment of peripheral arterial disease

Growth factor therapy versus placebo or no therapy for the treatment of peripheral arterial disease

Patient or population: people who have been diagnosed with peripheral arterial disease

Setting: all settings

Intervention: growth factor therapy

Comparison: placebo or no therapy

\begin{tabular}{|c|c|c|c|c|c|}
\hline \multirow[t]{2}{*}{ Outcomes } & \multirow{2}{*}{$\begin{array}{l}\text { № of participants } \\
\text { (studies) }\end{array}$} & \multirow{2}{*}{$\begin{array}{l}\text { Quality of the evidence } \\
\text { (GRADE }\end{array}$} & \multirow{2}{*}{$\begin{array}{l}\text { Relative effect } \\
(95 \% \mathrm{Cl})\end{array}$} & \multicolumn{2}{|c|}{ Anticipated absolute effects $(95 \% \mathrm{Cl})^{*}$} \\
\hline & & & & $\begin{array}{l}\text { Risk with placebo } \\
\text { or no therapy }\end{array}$ & $\begin{array}{l}\text { Risk difference } \\
\text { with growth factors }\end{array}$ \\
\hline $\begin{array}{l}\text { Major limb amputation } \\
\text { (follow-up: from } 3 \text { months to } 2 \text { years) }\end{array}$ & 1075 (10 RCTs) & $\begin{array}{l}\oplus \oplus \ominus \odot \text { low } a \\
(\oplus \oplus \oplus \ominus \text { moderate for } 1 \\
\text { year) }\end{array}$ & $\begin{array}{l}\text { OR } 0.99 \text { ( } 0.71 \text { to } \\
1.38)\end{array}$ & 19 per $100(86 / 452)$ & $\begin{array}{l}0 \text { per } 100 \\
\text { ( } 5 \text { fewer to } 5 \text { more) }\end{array}$ \\
\hline $\begin{array}{l}\text { Death } \\
\text { (follow-up: from } 3 \text { months to } 2 \text { years) }\end{array}$ & 1371 (12 RCTs) & $\begin{array}{l}\oplus \oplus \odot \odot \text { Low }^{a} \\
\text { ( } \oplus \oplus \oplus \odot \text { moderate for } 1 \\
\text { year) }\end{array}$ & $\begin{array}{l}\text { OR } 0.99 \text { ( } 0.69 \text { to } \\
1.41)\end{array}$ & 12 per $100(65 / 546)$ & $\begin{array}{l}0 \text { per } 100 \\
\text { ( } 3 \text { fewer to } 4 \text { more) }\end{array}$ \\
\hline $\begin{array}{l}\text { Serious adverse events } \\
\text { (follow-up: from } 3 \text { months to } 2 \text { years) }\end{array}$ & 1411 (13 RCTs) & $\begin{array}{l}\oplus \oplus \odot \odot \text { Low }^{a} \\
(\oplus \oplus \oplus \odot \text { moderate for } 1 \\
\text { year) }\end{array}$ & $\begin{array}{l}\text { OR } 1.09 \text { ( } 0.79 \text { to } \\
1.50)\end{array}$ & $\begin{array}{l}20 \text { per } 100 \\
(113 / 555)\end{array}$ & $\begin{array}{l}1 \text { more per } 100 \\
\text { (4 fewer to } 7 \text { more) }\end{array}$ \\
\hline $\begin{array}{l}\text { Any adverse event } \\
\text { (follow-up: from } 3 \text { months to } 2 \text { years) }\end{array}$ & 1411 (13 RCTs) & $\begin{array}{l}\oplus \oplus \odot \odot \text { Low }^{a} \\
(\oplus \oplus \oplus \odot \text { moderate for } 1 \\
\text { year) }\end{array}$ & $\begin{array}{l}\text { OR } 1.10 \text { ( } 0.73 \text { to } \\
1.64) \mathrm{c}\end{array}$ & $\begin{array}{l}82 \text { per } 100 \\
(338 / 555) \mathrm{c}\end{array}$ & $\begin{array}{l}1 \text { more per } 100 \\
\text { ( } 5 \text { fewer to } 6 \text { more) }\end{array}$ \\
\hline
\end{tabular}

*The basis for the anticipated risk in the study population was the average risk in the control group (i.e. the total number of participants with events divided by the total number of participants in the control group for all studies reporting the outcome). The estimation of the risk difference (and its $95 \%$ confidence interval) was based on the anticipated risk in the control group and the relative effect of the intervention (and its $95 \% \mathrm{Cl}$ ).

Cl: confidence interval;OR: odds ratio; $\mathbf{R C T}$ : randomised controlled trial. 
High quality: we are very confident that the true effect lies close to that of the estimate of the effect.

Moderate quality: we are moderately confident in the effect estimate: the true effect is likely to be close to the estimate of the effect, but there is a possibility that it is substantially different.

Low quality: our confidence in the effect estimate is limited: the true effect may be substantially different from the estimate of the effect.

Very low quality: we have very little confidence in the effect estimate: the true effect is likely to be substantially different from the estimate of effect.

aDowngraded by two levels due to imprecision and risk of bias; for 1 year only by one level due to imprecision.

bDowngraded by two levels due to risk of bias and selective reporting.

cEstimated from studies with aggregate data, since calculations from single events may cause bias due to multiple counting. 


\section{B A C K G R O U N D}

\section{Description of the condition}

Peripheral artery disease (PAD) commonly refers to stenosis (narrowing) and occlusion (blocking) of the peripheral arteries. While the most important cause of PAD is atherosclerosis, other non-acute or acute causes such as vasculitis, thrombosis and embolic disease are possible. Major risk factors for PAD are smoking, diabetes, dyslipidaemia and hypertension (Fowkes 2013; Tendera 2011). PAD may affect different vascular sites such as lower and upper extremities, the carotid and mesenteric vessels (Hirsch 2006; Tendera 2011). Due to clinical importance, we have limited the scope of this review to PAD of the lower extremity arteries.

While many PAD patients are asymptomatic, symptoms of varying severity may occur depending on the degree of stenosis and insufficiency of blood (i.e. oxygen) supply to the distal tissues. At a low degree of stenosis, PAD is characterised by leg pain induced during exercise or walking (intermittent claudication), and at a higher degree also by rest pain of the affected leg, ulceration and gangrene of the foot (critical limb ischaemia). Common classification systems for the clinical severity of PAD are the Fontaine and Rutherford classifications (Gardner 2008). PAD is a major cause of decreased mobility, functional capacity, quality of life and increases the risks of amputation and/or death (Hirsch 2006; Ouma 2012; Tendera 2011).

PAD affects $3 \%$ to $10 \%$ of the general population and $15 \%$ to $20 \%$ of people over 70 years of age and is slightly more prevalent in men than in women (Norgren 2007). Globally, 202 million people were living with PAD in $2010,69.7 \%$ of them in low- or middleincome countries (Fowkes 2013). The annual incidence of critical limb ischaemia ranges from 500 to 1000 and of major amputations from 120 to 500 new cases per million population (Tendera 2011). Since atherosclerosis is a systemic disease, PAD is associated with an increased risk of coronary artery and cerebrovascular diseases, which are the major causes of death in people with PAD (Tendera 2011).

According to current guidelines, the treatment strategy for people with PAD comprises behavioural modifications (e.g. smoking cessation, daily exercise, diet), drugs that decrease the risk of cardiovascular events (e.g. antiplatelet drugs, statins), and/ or drugs that improve PAD symptoms (Hirsch 2006; Rooke 2011; Tendera 2011). People with critical limb ischaemia are treated additionally either with catheter-based revascularisation or bypass surgery. A number of up-to-date Cochrane reviews have evaluated some of these treatments (Bedenis 2014; De Backer 2012; Lane 2014; Salhiyyah 2015). For people who fail to respond to conservative therapies and are not candidates for invasive procedures, there is no option to relieve symptoms other than amputation (Hirsch 2006; Tendera 2011).

\section{Description of the intervention}

With respect to PAD, the term 'growth factors' comprises all physiologically produced substances with the potential to stimulate new vessel formation (angiogenesis). The following growth factors have already shown the potential to promote angiogenesis and are of particular interest in people with PAD (Ouma 2012).
- Vascular endothelial growth factor (VEGF, isoforms: VEGF-A through -E).

- Placental growth factors (PLGF, isoforms: PLGF-1 and -2).

- Fibroblast growth factor (FGF, isoforms: 23 classes FGF-1 to FGF-23).

- Hepatocyte growth factor (HGF, isoforms HGF/NK1 and HGF/ NK2).

- Platelet-derived growth factor (PDGF, isoforms: PDGF-A through -D; 5 homo/heterodimers: PDGF-AA, -AB, -BB, -CC, and -DD).

- Angiopoietin (Ang, isoforms: Ang-1, -2, -3, and -4).

- Erythropoietin (EPO).

Growth factors may be delivered to the target tissues directly in the form of recombinant proteins (also using carriers like nanoparticles). The local increase in growth factors can also be achieved indirectly by substances promoting their gene expression (e.g. transcription factors), as well as by viral vectors, DNA plasmids encoding or by cells synthesising these factors (De Haro 2009; Ouma 2012). There are also different routes of application such as intramuscular (IM), intra-arterial and subcutaneous (Ouma 2012).

\section{How the intervention might work}

The exact mechanisms of growth factors' action in PAD are still unclear. Growth factors are important for regulating a variety of cellular processes. They bind to specific receptors on the surface of the target cells and may act by stimulating, for example, cellular growth, proliferation, differentiation and maturation. This promotes therapeutic angiogenesis and blood supply to the distal tissues. Therefore, growth factors may ameliorate the symptoms and prevent amputation in people with PAD (Ouma 2012).

\section{Why it is important to do this review}

Given the high clinical and socioeconomic burden of PAD of the lower extremities, treatments for its alleviation are a high societal priority. This is especially important for people with critical limb ischaemia whose option for approved therapy is only amputation.

Several growth factors have already shown the potential to stimulate angiogenesis in animal models. Therefore, their use has emerged as a promising strategy to treat patients with PAD (Ouma 2012). This systematic review of randomised clinical trials will help to determine benefits and harms of growth factor use in people with PAD.

\section{O B JECT IVES}

To assess the effects of growth factors that promote angiogenesis for treating people with PAD of the lower extremities.

\section{METHODS}

\section{Criteria for considering studies for this review}

\section{Types of studies}

Randomised controlled trials (RCTs).

\section{Types of participants}

People who have been diagnosed with PAD of the lower extremities (on clinical and investigative assessment). We did not place any restrictions on setting, age, sex or severity of PAD. 


\section{Types of interventions}

Intervention: growth factors delivered directly (as recombinant proteins) or indirectly (by substances promoting their gene expression, by viral vectors or DNA plasmids encoding or by cells synthesising these factors).

Comparison: no intervention, placebo or any other intervention not based on growth factor's action.

\section{Types of outcome measures}

\section{Primary outcomes}

1. Limb amputation

2. Death

3. Severe complications/adverse events (e.g. stroke, myocardial infarction, neoplasia)

\section{Secondary outcomes}

1. Walking ability (peak walking time/distance, claudication onset time/distance)

2. Haemodynamic measures (e.g. ankle brachial index (ABI), toe brachial index (TBI))

3. Ulceration (e.g. surface area, ulcer healing)

4. Rest pain (e.g. visual analogue scale (VAS), pain improvement)

\section{Search methods for identification of studies}

We did not apply any restrictions on date or language of publications.

\section{Electronic searches}

The Cochrane Vascular Information Specialist (CIS) searched the following databases for relevant trials.

- The Cochrane Vascular Specialised Register (9 June 2016).

- The Cochrane Central Register of Controlled Trials (CENTRAL; 2016, Issue 5) via the Cochrane Register of Studies Online.

See Appendix 1 for details of the search strategy used for CENTRAL.

The Cochrane Vascular Specialised Register is maintained by the CIS and is constructed from weekly electronic searches of MEDLINE Ovid, Embase Ovid, CINAHL and AMED as well as through handsearching relevant journals. The full list of the databases, journals and conference proceedings searched, as well as the search strategies used, are described in the Specialised Register section of the Cochrane Vascular module in the Cochrane Library (www.cochranelibrary.com).

In addition, the CIS searched the following trial databases for details of ongoing and unpublished studies (9 June 2016).

- World Health Organization (WHO) International Clinical Trials Registry Platform (ICTRP) Search Portal. (apps.who.int/ trialsearch).

- ClinicalTrials.gov (clinicaltrials.gov).

- International Standard Randomised Controlled Trial Number (ISRCTN) registry (www.isrctn.com).
- 'ischaemia' and 'growth factor';

- 'growth factor' and 'peripheral arterial'.

\section{Searching other resources}

We checked reference lists of relevant publications retrieved from the electronic searches to identify additional studies. If necessary, we also contacted the authors of publications and trialists of published, unpublished or ongoing trials for details of the studies.

\section{Data collection and analysis}

\section{Selection of studies}

Two review authors (VG, $\mathrm{AH}$ ) independently assessed the eligibility of the retrieved publications on studies for inclusion in the review; we resolved disagreements by consensus or by discussion with a third author (MUB). We performed the selection process in three stages, assessing titles, abstracts and full texts. We recorded the reasons for excluding any full-text publication in the Characteristics of excluded studies table.

\section{Data extraction and management}

One review author (VG) extracted information on trial participants and interventions using a standard data collection form developed by Cochrane Vascular, while a second author (AH) checked the extracted data. The two review authors independently recorded data concerning the outcome measures on forms developed by Cochrane Vascular, resolving disagreements by consensus. When necessary, we requested additional information from the study authors.

\section{Assessment of risk of bias in included studies}

We used Cochrane's tool for assessing risk of bias, provided by Cochrane Vascular, to assess allocation (selection bias); blinding of participants, clinical personnel and outcome assessors (performance bias and detection bias); incomplete outcome data (attrition bias); selective reporting (reporting bias); and other potential sources of bias (Higgins 2011). Two review authors (VG, $\mathrm{AH}$ ) independently assessed the risk of bias of each trial, resolving any disagreements by consensus. We judged each item of bias and produced a summary score of low, unclear or high risk of bias for each outcome of the study. We used the assessment of risk of bias to select the results of the studies at low risk of bias (judgments for all items relevant for this outcome at low risk of bias) for the main analyses, and for interpreting the quality (i.e. certainty) of the determined evidence.

\section{Measures of treatment effect}

We chose the effect measures for statistical analysis based on guidance from the Cochrane Handbook for Systematic Reviews of Interventions (Higgins 2011). We used the odds ratio (OR) as the measure of effect for dichotomous outcomes and mean difference (MD) for continuous outcomes. In case of different scales in the different studies, we standardised the results and used standardised mean differences (SMDs) where possible. We calculated the effect estimates with the corresponding 95\% confidence intervals $(\mathrm{Cls})$ and present the results graphically as forest plots.

The terms used to search were:

- 'claudication' and 'growth factor'; 


\section{Unit of analysis issues}

We used the participant as the unit of analysis in each trial and the trial as the unit for data synthesis. We performed separate analyses according to different periods of follow-up. We did not include studies with non-standard designs.

\section{Dealing with missing data}

We requested missing data regarding participant demographics, description of intervention, details of study design and outcome measures from study authors, if necessary. We considered incomplete outcome data (e.g. due to dropouts or non-response on questionnaires) to influence the risk of bias for these outcomes.

\section{Assessment of heterogeneity}

We evaluated clinical heterogeneity based on data for participants, interventions and outcomes of the studies. We also assessed the results of the studies with respect to statistical heterogeneity using the $1^{2}$ statistic and Cochrane's Q test according to the Cochrane Handbook for Systematic Reviews of Interventions (Higgins 2011). We considered an $\mathrm{I}^{2}$ greater than $30 \%$ or a $\mathrm{P}$ value of the $\mathrm{Chi}^{2}$ statistic of less than 0.1 to be indicative of statistical heterogeneity among the studies; an $\mathrm{I}^{2}$ greater than $50 \%$ indicated substantial statistical heterogeneity. In case of statistical heterogeneity we tried to explore possible causes.

\section{Assessment of reporting biases}

To minimise reporting bias, we checked registers of prospective trial registration. When appropriate, we applied funnel plots to assess publication bias.

\section{Data synthesis}

We performed data synthesis using Review Manager 5 software (RevMan 5) according to Cochrane Vascular guidelines (Review Manager 2014). We included studies at low risk of bias in the main analysis according to section 8.8.3.1 of Higgins 2011 and all studies in the sensitivity analysis. We combined data using different effect measures (OR, RR) and models (fixed-effect or random-effects). We present results of the studies and the meta-analyses (using OR with a fixed-effect model) in forest plots. We combined the results of the studies for all growth factors in the meta-analyses to increase precision of the effect estimates under the assumption of similar effect-sizes of different growth factors and their isoforms.

\section{Subgroup analysis and investigation of heterogeneity}

In case of sufficient data we planned to conduct the following subgroup analyses.

- Growth factors.

- Delivery approaches of growth factors.

- Routes of administration.

- PAD severity.

- Sex.

- Age groups.

\section{Sensitivity analysis}

We undertook a sensitivity analysis to examine the robustness of the observed findings by including the studies with a higher risk of bias in the meta-analysis. We assessed the robustness of the combined results in the meta-analysis using different statistical measures (OR, RR) and models (fixed-effect or random-effects).

\section{Summary of findings table}

We summarised the results of the analysis on primary outcomes in a 'Summary of findings' table. The 'Summary of findings' table also provides information concerning the quality of evidence for all comparisons. Two review authors (VG, $\mathrm{AH}$ ) independently assessed the quality (i.e. certainty) of the evidence for each outcome using the system developed by the GRADE working group by assessing risk of bias, indirectness, inconsistency, imprecision and publication bias (Balshem 2011). We resolved disagreements by consensus. As the context of the Cochrane Review users may differ (subsets of population, settings and modifications of the intervention), we made separate judgments about applicability of the evidence and the quality of evidence.

\section{RES U L T S}

\section{Description of studies}

Results of the search

See Figure 1. 


\section{Figure 1. Study flow diagram.}

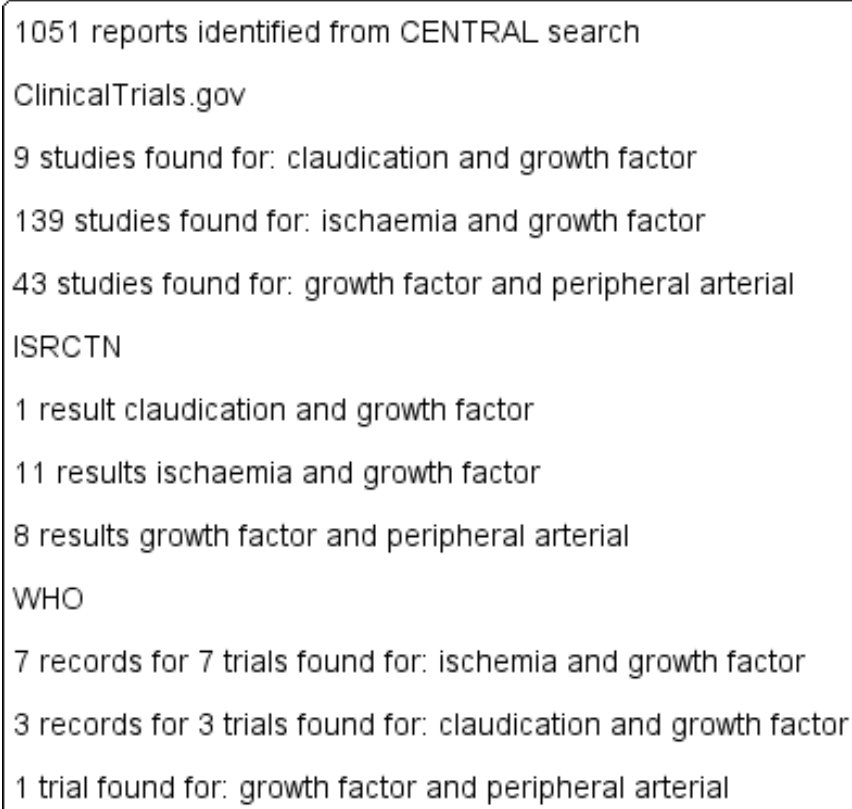

74 reports identified from the Specialised Register

1 report identified from reference lists

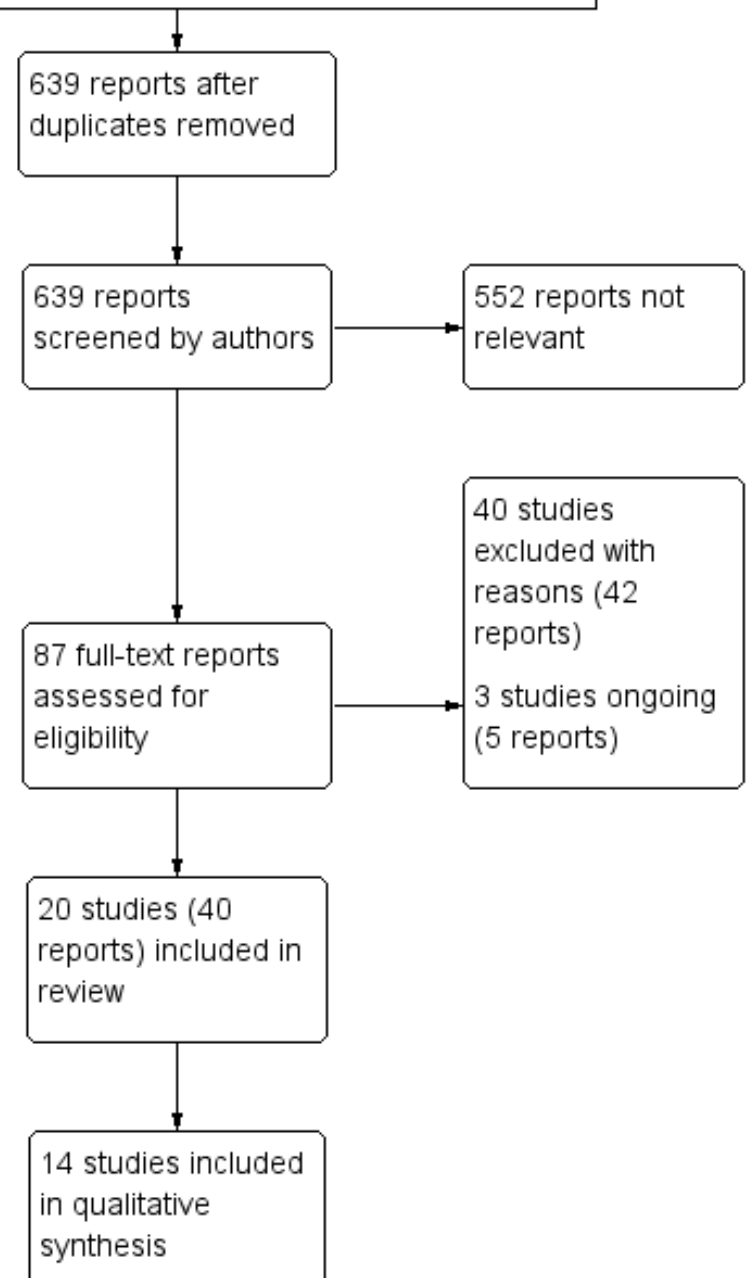


Figure 1. (Continued)

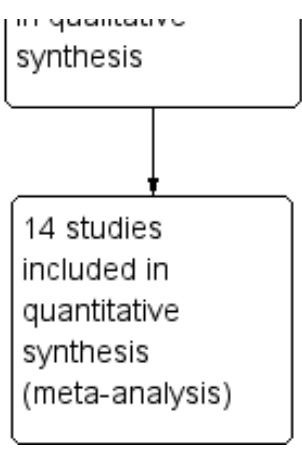

\section{Included studies}

Our review included 20 trials presented in 40 records (Cooper 2001; Deev 2015; HGF-0205; HGF-STAT; Kibbe 2016; Kusumanto 2006; Lazarous 2000; Makinen 2002; Matyas 2005; NCT00080392; NCT00304837; Rauh 1999; RAVE; Shigematsu 2010; TALISMAN-201; TALISMAN-202; TALISMAN-211; TAMARIS; TRAFFIC; VM202-China), and we used 14 trials with published results in the qualitative or quantitative analyses (see Table 1, Characteristics of included studies). Six of these studies exclusively or mainly investigated participants with intermittent claudication (Cooper 2001; Deev 2015; Lazarous 2000; Makinen 2002; RAVE; TRAFFIC), and eight studies included only participants with critical limb ischaemia (HGF-0205; HGF-STAT; Kibbe 2016; Kusumanto 2006; Matyas 2005; Shigematsu 2010; TALISMAN-201; TAMARIS). We requested additional information with respect to methodological issues and/ or results of the studies from the authors of all studies included in the analyses; however, we did not receive any responses.

\section{Fibroblast growth factor (FGF)}

Eight studies assessed FGF: three focused on fibroblast growth factor-2 ('basic fibroblast growth factor') for intermittent claudication (Cooper 2001; Lazarous 2000; TRAFFIC); four studies evaluated plasmid-delivered (non-viral) fibroblast growth factor-1 (NV1FGF) (TALISMAN-201; TALISMAN-202; TALISMAN-211; TAMARIS), and one adenovirus 5-delivered fibroblast growth factor-4 (Ad5FGF-4) (Matyas 2005) for critical limb ischaemia.

The first of the three studies on FGF-2 was a small doseescalation phase I trial including only 19 participants (Lazarous 2000), followed by a larger phase II multicentre trial including 190 participants (TRAFFIC). Both trials provided results for one or two doses of $30 \mu \mathrm{g} / \mathrm{kg}$ FGF-2, although the second dose was given on day 2 in Lazarous 2000 and on day 30 in TRAFFIC. The third trial investigated a 6 -week infusion of $2 \mu \mathrm{g} / \mathrm{kg}$ per week $(12 \mu \mathrm{g} / \mathrm{kg}$ FGF-2 in total) (Cooper 2001). Investigators did not finally implement the planned dose escalation in this study because early data from 24 participants (of the 108 who were to be enrolled) showed development of proteinuria in the treatment arm, prompting the premature termination of the study.

Of the four studies on NV1FGF, two had not been published at the time of writing the review, although both were completed in 2005: TALISMAN-202 $(\mathrm{N}=71)$ was a dose-escalating trial on five treatment regimens of NV1FGF at doses $2 \mathrm{mg}$ to $16 \mathrm{mg}$, while TALISMAN-211 ( $\mathrm{N}=36$ ) assessed two doses of NV1FGF, $16 \mathrm{mg}$ and $32 \mathrm{mg}$. Both published trials investigated the total doses of NV1FGF of $16 \mathrm{mg}$ (four sessions of eight injections) and included 125 or 525 participants, respectively (TALISMAN-201; TAMARIS).

There was also one small trial on Ad5FGF-4, which investigated escalating doses of $2.87 \times 10^{8}$ to $2.87 \times 10^{10}$ viral particles (Matyas 2005). The trial presented data for only 11 participants from a protocol with randomisation, as well as for 2 additional participants from a separate but comparable protocol (we do not include results for these participants in this review).

\section{Hepatocyte growth factors (HGF)}

Five trials investigated HGF, all studies delivered via plasmid, in participants with critical limb ischaemia. Three studies used the HGF plasmid product AMG0001 (HGF-STAT; HGF-0205; Shigematsu 2010). Two studies used the plasmid DNA pCK-HGF-X7, which expresses two isoforms of HGF (VM202 in Kibbe 2016 and NL003 in VM202-China).

Of three studies on AMG0001, the earliest was a dose-response study with 104 participants that investigated the total doses of 1.2 $\mathrm{mg}, 8 \mathrm{mg}$ and $12 \mathrm{mg} \mathrm{AMG0001}$ (in three sets of IM injections) (HGFSTAT). The second trial used only a total dose of $12 \mathrm{mg} \mathrm{AMG0001} \mathrm{(in}$ three sets of IM injections) and included 27 participants (HGF-0205). The third trial investigated only a total dose of $8 \mathrm{mg}$ AMG0001 (in two sets of IM injections); the study was terminated prematurely because of slow recruitment after an interim analysis based on data from the first 40 of the 120 planned participants (Shigematsu 2010).

One trial investigated HGF plasmid VM202 in total doses of $8 \mathrm{mg}$ and $16 \mathrm{mg}$ (in two or four sessions of IM injections, respectively) and included 52 participants with critical limb ischaemia (Kibbe 2016). The second trial was designed to use HGF plasmid NL003 in the total doses of $12 \mathrm{mg}, 18 \mathrm{mg}$ and $24 \mathrm{mg}$ (each in three sessions of IM injections) and included 200 participants (VM202-China); this study had not yet been published at the time of writing, although it was set to be completed in 2014.

\section{Vascular endothelial growth factor (VEGF)}

Seven trials assessed the effects of VEGF: five used genes encoding isoform VEGF-A (Deev 2015; Kusumanto 2006; Makinen 2002; NCT00080392; RAVE), and two isoform VEGF-C (NCT00304837; Rauh 1999). The results of both studies on isoform VEGF-C (in participants with critical limb ischaemia) and of one small study on isoform VEGF-A (in 10 participants with intermittent claudication) have not been published yet (NCT00304837; NCT00080392; Rauh 1999). 
Of four published trials on isoform VEGF-A, one used variant VEGF121 (RAVE). This study included 105 participants with intermittent claudication and investigated the effect of two doses (4 $\times 10^{9}$ or $4 \times 10^{10}$ particle units) of recombinant adenovirus encoding VEGF121, which were applied through IM injections.

Three other published trials on isoform VEGF-A used the variant VEGF165. Makinen 2002 investigated its effect separately for adenovirus $\left(2 \times 10^{10}\right.$ particle units) and plasmid $(2000 \mu \mathrm{g})$ gene delivery through intra-arterial infusion over balloon catheter after percutaneous transluminal angioplasty; the study included 54 participants with PAD, 14 of them with critical limb ischaemia. One other trial on variant VEGF165, Kusumanto 2006, included only 54 diabetic participants with critical limb ischaemia and delivered VEGF165 as plasmid $(2000 \mu \mathrm{g})$ in two series of IM injections. Deev 2015 included 100 participants with PAD, 13 of them with critical limb ischaemia, investigating smaller doses of VEGF165 plasmid $(1200 \mu \mathrm{g})$, also administered in two series of IM injections.

\section{Excluded studies}

We excluded 40 studies following full-text assessment. The reasons for exclusion were: participants without PAD disease, no separate analysis for participants with PAD, irrelevant therapy or comparator, therapy effect based not only on growth factor action, or published study is not RCT (see Characteristics of excluded studies).

\section{Risk of bias in included studies}

We present the review authors' judgments and justification for each risk of bias item for each included study in the Characteristics of included studies table. Figure 2 summarises the judgments about each risk of bias item for all studies. 
Figure 2. Risk of bias summary: review authors' judgments about each risk of bias item for each included study.

\begin{tabular}{|c|c|c|c|c|c|c|c|c|c|c|c|c|c|c|}
\hline & 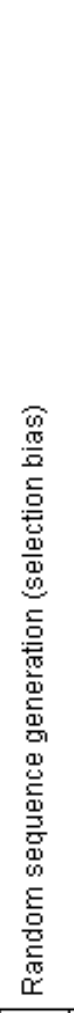 & 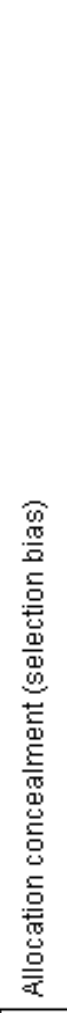 & 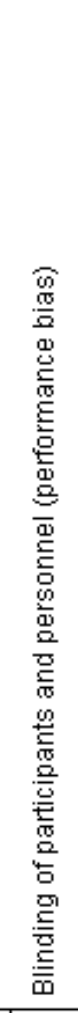 & 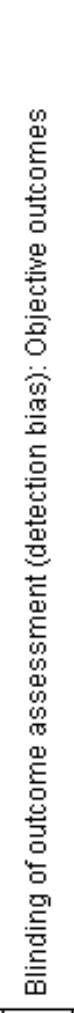 & 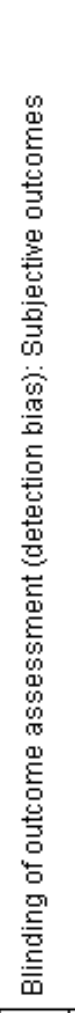 & 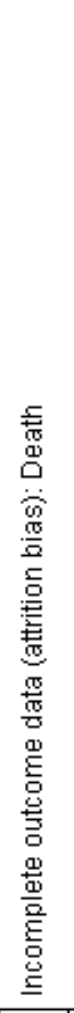 & 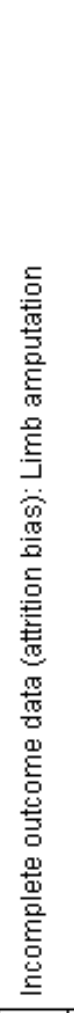 & 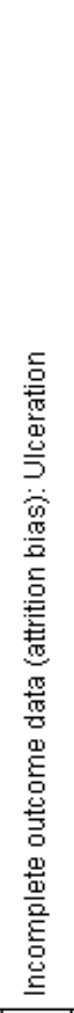 & 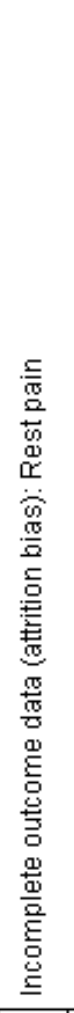 & 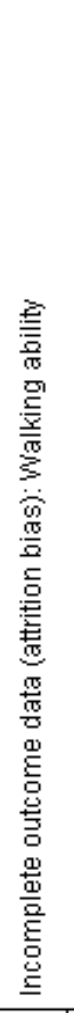 & 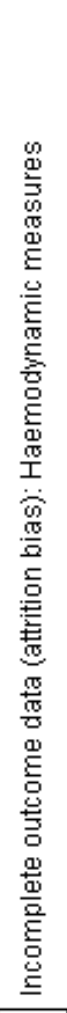 & 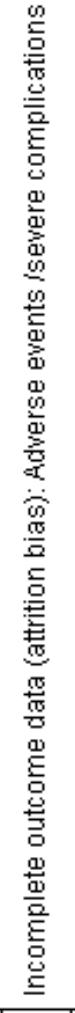 & 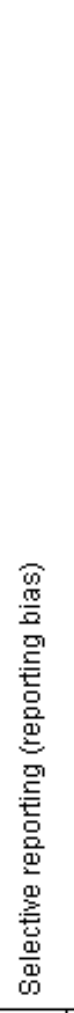 & 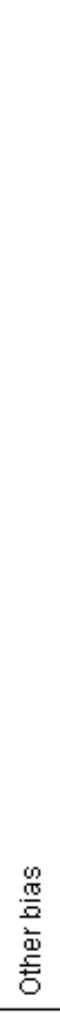 \\
\hline Cooper 2001 & $?$ & $?$ & $?$ & + & $?$ & + & $?$ & $?$ & $?$ & $?$ & $?$ & + & $?$ & $\odot$ \\
\hline Deev 2015 & $\odot$ & $?$ & $\odot$ & 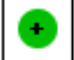 & $\odot$ & $\oplus$ & + & $?$ & $?$ & $?$ & $?$ & + & $\oplus$ & + \\
\hline HGF-0205 & $?$ & $?$ & $?$ & + & $?$ & $\odot$ & $\odot$ & 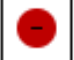 & 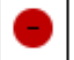 & $?$ & 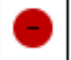 & + & $\oplus$ & 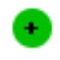 \\
\hline HGF-STAT & $?$ & $?$ & $?$ & + & $?$ & + & $?$ & 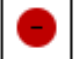 & $?$ & $?$ & - & + & $?$ & + \\
\hline Kibbe 2016 & $?$ & $?$ & $?$ & $\odot$ & $?$ & $\odot$ & $\odot$ & $\odot$ & $\odot$ & $?$ & $?$ & 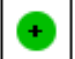 & $\odot$ & $\oplus$ \\
\hline Kusumanto 2006 & + & + & $?$ & + & $?$ & + & + & $O$ & $\odot$ & $?$ & 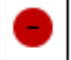 & + & $\oplus$ & + \\
\hline Lazarous 2000 & $?$ & $?$ & $?$ & + & $?$ & + & $?$ & $?$ & $?$ & + & + & + & $?$ & + \\
\hline Makinen 2002 & $\odot$ & $?$ & + & + & + & + & $\odot$ & $\theta$ & $\odot$ & $?$ & $?$ & + & + & + \\
\hline Matyas 2005 & $?$ & $?$ & + & + & $\odot$ & + & $\odot$ & $\odot$ & $\odot$ & $?$ & $\odot$ & $\odot$ & $\odot$ & $\odot$ \\
\hline NCT00080392 & $?$ & $?$ & $?$ & + & $?$ & $?$ & $?$ & $?$ & $?$ & $?$ & $?$ & $?$ & 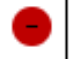 & $?$ \\
\hline NCT00304837 & $?$ & $?$ & $?$ & + & $?$ & $?$ & $?$ & $?$ & $?$ & $?$ & $?$ & $?$ & 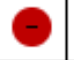 & $?$ \\
\hline Rauh 1999 & $?$ & $?$ & $?$ & + & $?$ & $?$ & $?$ & $?$ & $?$ & $?$ & $?$ & $?$ & 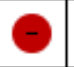 & $?$ \\
\hline RAVE & $?$ & $?$ & $?$ & + & $?$ & + & $\odot$ & $?$ & $?$ & $\odot$ & $?$ & $\odot$ & $\odot$ & $\odot$ \\
\hline Shigematsu 2010 & + & + & $\odot$ & + & $?$ & + & $\odot$ & $\theta$ & 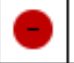 & $?$ & $?$ & + & $\odot$ & + \\
\hline TALISMAN-201 & $?$ & $?$ & $?$ & + & $?$ & + & $\Theta$ & - & 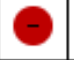 & $?$ & 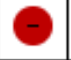 & + & + & + \\
\hline TALISMAN-202 & $?$ & $?$ & $?$ & + & $?$ & $?$ & $?$ & $?$ & $?$ & $?$ & $?$ & $?$ & $\odot$ & $?$ \\
\hline
\end{tabular}


Figure 2. (Continued)

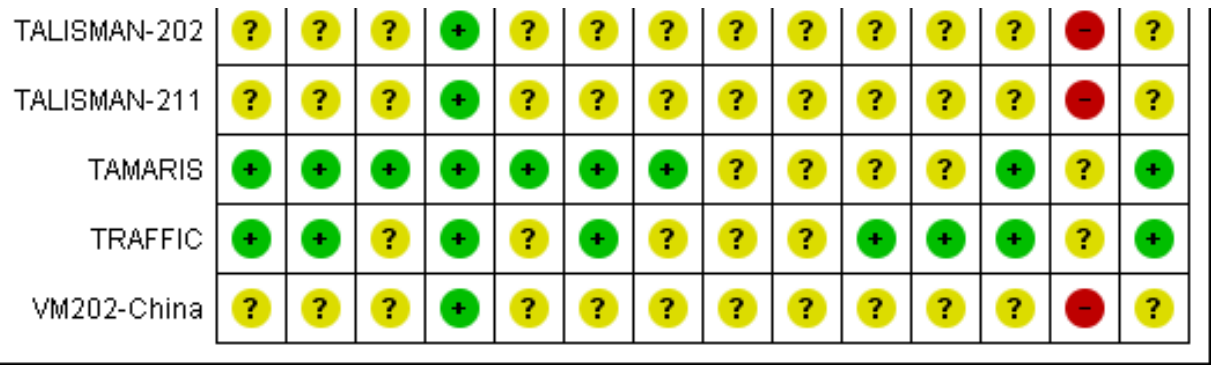

\section{Allocation}

Only five trials report appropriate details on random sequence generation (Kusumanto 2006; Makinen 2002; Shigematsu 2010; TAMARIS; TRAFFIC), and just four trials described allocation concealment (Kusumanto 2006; Shigematsu 2010; TAMARIS; TRAFFIC). It is unclear whether many trials retrospectively excluded randomised participants who did not receive any intervention. Therefore, we assigned the judgment of 'low risk' of selection bias to only four trials (Kusumanto 2006; Shigematsu 2010; TAMARIS; TRAFFIC). Moreover, the randomisation in Deev 2015 was probably not truly performed, suggesting a high risk of selection bias for this trial. We judged the remaining trials to be at unclear risk of selection bias.

\section{Blinding}

Authors describe all trials but Deev 2015 as being double-blind. However, just four studies described the blinding procedure of participants and personnel in enough detail to permit judgment of 'low risk' of performance bias (Makinen 2002; Matyas 2005; Shigematsu 2010; TAMARIS). Authors of Deev 2015 describe it as an open-label study, suggesting a high risk of performance bias. We judged the remaining trials to be at unclear risk of performance bias.

We assume that the risk of bias due to subjective assessment of some outcomes is negligent (death, limb amputation, adverse events/severe complications, haemodynamic parameters and ulceration). Moreover, some trials performed additional steps to mask certain measurements and data analysis. Therefore, we judged all studies to be at low risk of detection bias for objective outcomes. However, only three studies explicitly provided sufficient data on the blinding of participants to permit a judgment of low risk of detection bias for highly subjective outcomes (rest pain and walking ability) (Makinen 2002; Matyas 2005; TAMARIS). Deev 2015 was an open-label study, suggesting a high risk of detection bias for subjective outcomes. We considered the remaining studies to be at unclear risk of detection bias for subjective outcomes.

\section{Incomplete outcome data}

We deemed the risk of attrition bias to be unclear for study outcomes that were not measured or published (Figure 2). Data for adverse events and for death are complete in all published trials as well as data for amputations in eight trials (Deev 2015; Kibbe 2016; Kusumanto 2006; Makinen 2002; Matyas 2005; RAVE; Shigematsu 2010; TAMARIS); we judged these outcomes to be at low risk of bias for these trials. For efficacy analysis, two trials used the so-called modified intention-to-treat (MITT) population, which included only participants who received at least two (in TALISMAN-201) or all three (in HGF-0205) treatment doses; therefore, results for all measured efficacy outcomes in these studies may be biased. The risk of attrition bias is also high for the outcomes of rest pain (Kusumanto 2006; Makinen 2002; Shigematsu 2010), ulceration (HGF-STAT; Kibbe 2016; Kusumanto 2006; Makinen 2002; Shigematsu 2010), and haemodynamic parameters (HGFSTAT; Kusumanto 2006), which were based on less than $70 \%$ of randomised participants. Due to a low proportion of missing data, the risk of attrition bias is low for the outcome ulceration in one trial (Matyas 2005), for rest pain in two (Kibbe 2016; Matyas 2005), for walking ability in three (Lazarous 2000; RAVE; TRAFFIC), and for haemodynamic parameters in three (Lazarous 2000; Matyas 2005; TRAFFIC). For the remaining outcomes, the risk of attrition bias is unclear because the studies do not report the number of participants with corresponding measurements.

\section{Selective reporting}

Some trials were completed but their results unpublished (NCT00080392; NCT00304837; Rauh 1999; TALISMAN-202; TALISMAN-211; VM202-China), suggesting a risk of publication bias. One study measured but didn't report results for a number of secondary outcomes: ulceration, rest pain and haemodynamic parameters (because "the primary outcome was non-significant") (TAMARIS). Three trials did not explicitly provide data for limb amputations (Cooper 2001; Lazarous 2000; TRAFFIC), one for deaths (Lazarous 2000), and many trials for secondary outcomes. In HGF-STAT, the presented results for death, limb amputations, haemodynamic parameters and rest pain are only descriptive and thus insufficient. Therefore, the risk of selective reporting bias for these studies is unclear. For the other trials, the risk of selective reporting bias is low.

\section{Other potential sources of bias}

The studies with published results appear to be free of other potential sources of bias. For other trials, there was insufficient information available to assess whether an important risk of bias exists (NCT00080392; NCT00304837; Rauh 1999; TALISMAN-202; TALISMAN-211; VM202-China).

\section{Effects of interventions}

See: Summary of findings for the main comparison Growth factors versus placebo or no therapy for the treatment of peripheral arterial disease

Table 2 shows the reported parameters of each study. The results of meta-analyses are presented in the section Data and analyses. See also Summary of findings for the main comparison 


\section{Limb amputation}

Seven studies provide results for major amputations (HGF-0205; Kibbe 2016; Kusumanto 2006; Makinen 2002; TALISMAN-201; TAMARIS; Shigematsu 2010); three of these studies also reported results for all amputations (Kibbe 2016; TALISMAN-201; Shigematsu 2010). Three other studies did not specify the types of reported amputations (Deev 2015; Matyas 2005; RAVE). Most reported followup periods ranged from three months to one year. Two small trials provided data for two years (Deev 2015; Makinen 2002), and one of these trials also reported data at 10 years (Makinen 2002).

\section{Size of the effect}

In the main analysis, we could only derive an OR estimate at low risk of bias for major limb amputations from a single trial with data at one year (TAMARIS); the study observed similar rates of major limb amputations in the treatment (growth factors therapy) and control groups ( $25 \%$ versus $21 \%$; OR $1.25,95 \% \mathrm{Cl} 0.83$ to $1.88 ; 525$ participants).

In the sensitivity analysis, the conducted meta-analysis found similar rates of major limb amputations in the treatment and control groups using either the data for one year ( $18 \%$ versus 21\%; OR $1.00,95 \% \mathrm{Cl} 0.71$ to 1.41 ; 6 studies; 916 participants; Analysis 1.1) or the latest available data up to two years (16\% versus 19\%; OR $0.99,95 \% \mathrm{Cl} 0.71$ to 1.38 ; 10 studies; 1075 participants; Analysis 1.2). The meta-analysis revealed decreased rates of any limb amputation in the treatment group using both the data for one year (14\% versus $30 \%$; OR $0.54,95 \%$ Cl 0.29 to 1.00 ; 4 studies; 364 participants; Analysis 1.3) and the latest available data for up to two years (14\% versus $28 \%$; OR $0.56,95 \% \mathrm{Cl} 0.31$ to $0.99 ; 6$ studies; 415 participants; Analysis 1.4). There was no or low heterogeneity between the trials and between the subgroups of growth factors in the conducted analyses (besides in the FGF subgroup for major limb amputations). We found similar results in the corresponding metaanalyses using risk ratio and/or the random-effects model. One trial observed similar rates of limb amputations in the treatment and control groups at 10 years ( $9 \%$ versus 5\%; 54 participants; Makinen 2002).

\section{Quality of evidence}

The evidence on limb amputations was direct. A potential publication bias and selective reporting (relevant for any amputations) may mask results not showing efficacy of growth factors. The evidence for major limb amputations at one year was at low risk of bias; the results were generally consistent between the main and the sensitivity analyses. However, due to imprecision (based on $95 \% \mathrm{Cl}$, we cannot rule out a clinically relevant effect) the quality of evidence for major limb amputations at one year is moderate. The quality of evidence for major limb amputations for other time points is low due to risk of bias and imprecision. The quality of evidence for any limb amputation is low due to risk of bias and selective reporting (only three studies explicitly report results).

\section{Summary judgment}

The direction and magnitude of the effect for growth factors on major limb amputations in people with PAD of the lower extremities is uncertain (low-quality evidence, but moderate-quality evidence at one year). However, growth factors may decrease the rate of any amputations (low-quality evidence).

\section{Death}

Twelve trials explicitly provide results for death (Cooper 2001; Deev 2015; HGF-STAT; HGF-0205; Kibbe 2016; Kusumanto 2006; Makinen 2002; Matyas 2005; RAVE; TALISMAN-201; TAMARIS; TRAFFIC). Most reported follow-up periods ranged from three months to one year. Two small trials provided data for two years (Deev 2015; Makinen 2002), and one of these trials also reported data at 10 years (Makinen 2002).

\section{Size of the effect}

In the main analysis, we could only derive an OR estimate at low risk of bias for death from a single trial with data at one year (TAMARIS); the study observed similar rates of death in the treatment and control groups ( $17 \%$ versus 15\%; OR $1.18,95 \% \mathrm{Cl} 0.74$ to 1.88 ; 525 participants).

In the sensitivity analysis, the meta-analysis showed similar rates of death in the treatment and control groups using either the data for one year ( $12 \%$ versus $14 \%$; OR $0.98,95 \% \mathrm{Cl} 0.67$ to $1.44 ; 7$ studies; 1038 participants; Analysis 1.5) or using the latest available data up to two years ( $9 \%$ versus $12 \%$; OR $0.99,95 \% \mathrm{Cl} 0.69$ to $1.41 ; 12$ studies; 1371 participants; Analysis 1.6). We found no heterogeneity in the meta-analyses between the trials or between the subgroups of growth factors. We found similar results when using risk ratio and/or the random-effects model in the meta-analyses. We also observed similar rates of death in the treatment and control groups in one trial at 10 years (46\% versus 53\%; 54 participants; Makinen 2002).

\section{Quality of evidence}

The evidence on death was direct. The risk of publication bias and of selective reporting for death is low. The evidence for one year was at low risk of bias; the results were consistent between the main and the sensitivity analyses. However, due to imprecision (based on $95 \% \mathrm{Cl}$, we cannot rule out a clinically relevant effect), the quality of evidence for one year is moderate. The quality of evidence for other time points is low due to risk of bias and imprecision of the data.

\section{Summary judgment}

The direction and magnitude of the effect of growth factors on death in people with PAD of the lower extremities is uncertain (lowquality evidence, but moderate-quality evidence at one year).

\section{Severe complications/adverse events}

All studies investigated adverse events. Many trials reported aggregate data on serious adverse events, some trials on all adverse events or on severe adverse events. Several trials did not provide aggregate data but only data for a single or group of adverse events. Most reported follow-up periods ranged from three months to one year. Two small trials provided data for up to two years (Deev 2015; Makinen 2002), and one of these also reported data at 10 years (Makinen 2002).

\section{Size of the effect}

In the main analysis, we could only derive an OR estimate at low risk of bias for adverse events from a single trial with data for one year (TAMARIS). The study observed similar rates of serious adverse events ( $9 \%$ versus $6 \%$; OR $1.60,95 \% \mathrm{Cl} 0.82$ to $3.12 ; 525$ participants) and of any adverse events ( $80 \%$ versus $80 \%$; OR $1.04,95 \% \mathrm{Cl} 0.68$ 
to $1.60 ; 525$ participants) at one year in the treatment and control groups.

In the sensitivity analyses, the meta-analyses using available data up to two years showed similar rates of serious adverse events in both groups based either only on studies with aggregate data (31\% versus $24 \%$; OR 1.11 , $95 \% \mathrm{Cl} 0.74$ to 1.65 ; 6 studies; 865 participants; Analysis 1.7) or on all studies (i.e. including self-calculated overall event numbers for trials reporting only data for single events) (23\% versus $20 \%$; OR $1.09,95 \%$ Cl 0.79 to 1.50 ; 13 studies; 1411 participants; Analysis 1.8). The results of the trials showed low or no heterogeneity (besides in the FGF subgroup). However, the non-heterogeneous ORs of the trials with reported aggregate data on any adverse events became moderately heterogeneous when we included self-calculated overall event numbers from trials providing only data for single events in the analysis $(12=36 \%, P=$ 0.10). The meta-analysis for any adverse events also showed similar rates in both groups based either only on the reported aggregate data ( $84 \%$ versus $82 \%$; OR $1.10,95 \% \mathrm{Cl} 0.73$ to $1.64 ; 4$ studies; 709 participants; Analysis 1.9) or on all studies (i.e. including selfcalculated event numbers) (61\% versus $61 \%$; OR $1.52,95 \% \mathrm{Cl} 1.15$ to $2.02 ; 13$ studies; 1411 participants; Analysis 1.10). We found no or low heterogeneity in the meta-analyses between the subgroups of growth factors. There were similar results when using only data for one year and when using risk ratio and/or the random-effects model in the meta-analyses. Likewise, we observed similar rates of adverse events in the treatment and control groups in one trial at 10 years (44\% versus 43\%; 54 participants; Makinen 2002).

\section{Quality of evidence}

The evidence on adverse events was direct. We do not expect any relevant publication bias or selective reporting for safety results. The evidence for one year was at low risk of bias; the results were generally consistent between the main and the sensitivity analyses as well as between analyses based on only studies with aggregate data and on all studies (although the self-calculated event numbers may cause bias due to multiple counting). However, there was some imprecision of the effect estimate (based on $95 \% \mathrm{Cl}$, we cannot rule out a relevant increase of serious adverse events). Therefore, the quality of evidence for one year is moderate. The quality of evidence for other time points is low due to risk of bias and imprecision of the data.

\section{Summary judgment}

The direction and magnitude of the effects for growth factors on serious and on any adverse events in people with PAD of the lower extremities are uncertain (low-quality evidence, but moderatequality evidence at one year).

\section{Walking ability}

Results for walking ability were available from five of six trials including participants with intermittent claudication (Cooper 2001; Deev 2015; Lazarous 2000; RAVE; TRAFFIC). Three studies reported results for the peak walking time and for the claudication onset time up to six months (Cooper 2001; RAVE; TRAFFIC). One small study reported results for the pain-free walking distance for six months, 12 months and two years (Deev 2015).

\section{Size of the effect}

We could not perform the main analysis, as the only trial that could provide results at low risk of bias did not report these parameters (TAMARIS).

The sensitivity meta-analyses derived from the latest available data up to six months revealed no clinically important difference between the treatment and control groups in peak walking time (MD $-0.17 \mathrm{~min}, 95 \% \mathrm{Cl}-0.69$ to 0.36 ; 3 studies; 279 participants; Analysis 1.11) or in claudication onset time (MD -0.07 min, 95\% $\mathrm{Cl}-0.31$ to 0.17 ; 3 studies; 279 participants; Analysis 1.12). We found no or low heterogeneity between the trials and between the subgroups of growth factors, although there was moderate heterogeneity between the subgroups for claudication onset time $(12=56 \% ; P=0.13)$. We found similar results in the meta-analyses using the random-effects model. However, the mean pain-free walking distance investigated in one small study increased in the treatment group compared to the control group at six months, 12 months and two years (151 m, $231 \mathrm{~m}$ and $251 \mathrm{~m} ; 100$ participants).

\section{Quality of evidence}

The evidence on walking ability was direct, and the effect estimates of the meta-analyses were precise, precluding a clinically relevant effect. We do not expect a relevant publication bias or selective reporting for walking ability. However, the evidence came only from the study results at unclear or high risk of bias. In addition, there was some inconsistency between the results for different parameters. Therefore, we judged the quality of evidence to be low.

\section{Summary judgment}

Growth factors have little or no effect on walking ability in people with PAD of the lower extremities (low-quality evidence).

\section{Haemodynamic measures}

Each trial measured at least one haemodynamic parameter (mostly $\mathrm{ABI}$ or $\mathrm{TBI}$ ), but studies often presented the results only graphically, descriptively or without data for the number of participants with measurements or for variability. The reported follow-up ranged from three months to nine months. Two studies provided results for $\mathrm{ABI}$ at one year (Deev 2015; Kibbe 2016), and one provided data at two years (Deev 2015). One small study reported data on haemodynamic improvement (defined as absolute increase more than $15 \%$ in the $\mathrm{ABI}$ or TBI values) at three months (Kusumanto 2006).

\section{Size of the effect}

We could not perform the main analysis, as the only trial that could provide results at low risk of bias did not report these parameters (TAMARIS).

In the sensitivity meta-analyses, we could include only results from six trials for ABI (Deev 2015; HGF-0205; Kibbe 2016; Makinen 2002; Matyas 2005; TALISMAN-201) and from two trials for TBI (HGF-0205; TALISMAN-201), derived from the latest available data up to six months. The meta-analysis showed a small increase in mean $A B I$ in the treatment group (MD $0.04,95 \% \mathrm{Cl}-0.02$ to $0.10 ; 6$ studies; 341 participants; Analysis 1.13). We found no heterogeneity for $A B I$ between the trials or between the subgroups of growth factors. However, the effect estimates between the trials and between the subgroups for change in TBI from baseline were substantially 
heterogeneous $\left(\mathrm{I}^{2}=89 \% ; \mathrm{P}=0.003\right)$; the meta-analysis showed a small increase in mean TBI in the treatment group (MD 0.04, $95 \% \mathrm{Cl}-0.01$ to $0.09 ; 2$ studies; 128 participants; Analysis 1.14). We found similar results in the meta-analyses using the randomeffects model. Results from trials for mean change in $A B I$ within one year and within two years showed similar differences between groups. However, one small study showed an increased rate of participants with haemodynamic improvement at three months in the treatment group (33\% versus 6\%; 54 participants).

\section{Quality of evidence}

The evidence on haemodynamic measures was direct and was generally consistent between results for different parameters. However, the effect estimates of the meta-analyses were imprecise, and we cannot rule out negative effects for growth factors on haemodynamic measures. Moreover, we could only derive the effect estimates from studies at unclear or high risk of bias. In addition, the potential publication bias and particularly selective reporting may mask results not showing efficacy of growth factors. Therefore, we judged the quality of evidence as low.

\section{Summary judgment}

Growth factors may improve haemodynamic measures up to six months in people with PAD of the lower extremities (low-quality evidence).

\section{Ulceration}

Overall, 9 of 10 trials including participants with critical limb ischaemia measured ulceration, and 8 presented results (HGF-0205; HGF-STAT; Kibbe 2016; Kusumanto 2006; Makinen 2002; Matyas 2005; Shigematsu 2010; TALISMAN-201). Two trials presented data with respect to change in the ulceration area within six months (HGF-0205; HGF-STAT; we could not pool results, as no data on standard deviations (SD) were available in the HGFSTAT study). Kibbe 2016 and Shigematsu 2010 presented results for rates of participants with more than $50 \%$ (and Kusumanto 2006 with more than 60\%) improvement in ulcer size at 3 months to 12 months' follow-up. Seven studies provided results for rates of participants with complete ulcer healing at up to one year (HGF-0205; HGF-STAT; Kibbe 2016; Makinen 2002; Matyas 2005; TALISMAN-201; Shigematsu 2010).

\section{Size of the effect}

We could not perform the main analysis, as the only trial that could provide results at low risk of bias did not report these parameters (TAMARIS).

The sensitivity analysis using last available data up to one year revealed an increased rate of participants with improvement in ulcer size (63\% versus $11 \%$; OR $17.57,95 \% \mathrm{Cl} 3.37$ to 91.65 ; 3 studies; 79 participants; Analysis 1.16) and an increased rate of participants with complete ulcer healing (33\% versus $16 \%$; OR 1.88, 95\% Cl 0.89 to 3.97 ; 6 studies; 189 participants; Analysis 1.15 ) in the treatment group. There was no or low heterogeneity between the trials and between the subgroups of growth factors for both parameters. We found similar results in the meta-analyses using risk ratio and/or the random-effects model.

\section{Quality of evidence}

The evidence on ulceration was direct and was generally consistent between results for both parameters. However, the effect estimates of the meta-analyses were imprecise, and we cannot rule out negative effects of growth factors for complete ulcer healing. Moreover, we could only derive the effect estimates from the study results at unclear or high risk of bias. In addition, the probable publication bias and selective reporting may mask results not showing efficacy of growth factors. Therefore, we judged the quality of evidence as very low.

\section{Summary judgment}

Growth factors may improve ulceration up to one year in people with PAD of the lower extremities (very low-quality evidence).

\section{Rest pain}

Overall, 9 of 10 trials including participants with critical limb ischaemia measured rest pain, and 8 presented results (HGF-0205; HGF-STAT; Kibbe 2016; Kusumanto 2006; Makinen 2002; Matyas 2005; Shigematsu 2010; TALISMAN-201). Four trials used a visual analogue scale (VAS) to measure changes in level of rest pain from baseline up to one year (HGF-0205; Kibbe 2016; Matyas 2005; TALISMAN-201). Six trials reported results for rates of participants with improvement in rest pain up to nine months (HGF-STAT; Kibbe 2016; Kusumanto 2006; Makinen 2002; Matyas 2005; Shigematsu 2010).

\section{Size of the effect}

We could not perform the main analysis, as the only trial that could provide results at low risk of bias did not report these parameters (TAMARIS).

In the sensitivity analysis, the conducted meta-analysis revealed a decrease in the mean VAS score up to one year (MD at $10 \mathrm{~cm}$ scale $-1.09 \mathrm{~cm}, 95 \% \mathrm{Cl}-1.83$ to -0.35 ; 4 studies; 191 participants; Analysis 1.17) and an increased rate of participants with improvement in rest pain up to nine months (44\% versus $27 \%$; OR $1.89,95 \% \mathrm{Cl} 0.80$ to 4.42 ; 5 studies; 133 participants; Analysis 1.18) in the treatment group. There was no or low heterogeneity between the trials and between the subgroups of growth factors for both parameters. We found similar results in the meta-analyses using the random-effects model for both parameters and/or calculating the risk ratio for the improvement in rest pain.

\section{Quality of evidence}

The evidence on rest pain was direct and consistent between results for both parameters. However, the effect estimates of the metaanalyses were imprecise, not precluding negative effects of growth factors for improvement in rest pain. Moreover, the effect estimates could be derived only from the study results at unclear or high risk of bias. In addition, the probable publication bias and selective reporting may mask results not showing efficacy of growth factors. Therefore, the quality of evidence is very low.

\section{Summary judgment}

Growth factors may improve rest pain up to one year in people with PAD of the lower extremities (very low-quality evidence). 


\section{DISCUSSION}

\section{Summary of main results}

Our systematic review identified 20 randomised trials assessing three growth factors (FGF, HGF and VEGF; delivered directly or via substances promoting their gene expression) in people with different clinical stages of PAD of the lower extremities. Since six of the conducted trials had not been published at the time of writing this review, we could use the results of only 14 of these trials in the analyses. Most reported follow-up periods ranged from three months to one year. Two small studies provided some data for 2 years, and one of them also for 10 years.

Our systematic review shows, that although growth factors may improve haemodynamic measures as well as ulceration and rest pain in people with PAD of the lower extremities up to one year, they have little or no effect on walking ability. Moreover, as the rate of any amputations was decreased but the rate of major amputations was similar, growth factors may decrease the rate of minor limb amputations. However, their effects on major limb amputations and on death are uncertain. The effect of growth factors on serious adverse events and on any adverse events is also uncertain. We did not identify any relevant differences in effects between growth factors (FGF, HGF and VEGF).

\section{Overall completeness and applicability of evidence}

The body of evidence is based on a broad spectrum of participants with respect to age, sex and severity of PAD (different clinical stages of intermittent claudication or of critical limb ischaemia), but participants were mostly white people living in the West. Sufficient data were not available for subgroup analyses with respect to age, sex, PAD severity, delivery approaches of growth factors and routes of application. Moreover, as these studies investigated only FGF, HGF and VEGF, the effect of other growth factors on people with PAD remains unclear. Since only one small study reported data over two years, the long-term effects of growth factors in people with PAD are uncertain.

Although the review results are based on approximately 1400 participants, the total number of randomised participants and of obtained events, especially from the studies at low risk of bias, was low. Therefore, for most outcomes our analysis lacked the statistical power to provide precise effect estimates of treatment effects.

Although we considered many aspects of applicability such as biologic variability, variability in context, culture, adherence, values and preferences, we think that there are no major concerns about the applicability of the determined evidence of this review. We identified a number of ongoing trials that will probably be available for future updates of this review and should support the completeness of the evidence (Characteristics of ongoing studies).

\section{Quality of the evidence}

We identified six randomised trials with more than 300 participants (mostly in people with critical limb ischaemia), which were completed before 2015 but had not been published at the time of writing. Since trials that fail to show efficacy are less likely to be published, publication bias could influence the results for some outcomes showing an effect of growth factors. There may be a similar effect if the studies do not report results for all measured outcomes. Some publications reported the results of the trials insufficiently: either only descriptively, without data on variability (SD or SE levels) or without the number of participants with measurements in the follow-up, which hampers the use of these results in the meta-analyses. To minimise publication and reporting bias, we requested all missing data from the authors but unfortunately did not receive any response.

Although analyses for some evaluated parameters showed effects for growth factors, these effects may be due to chance or (more likely) bias, not only to true effect. Bias may be particularly responsible for effect estimates favouring therapy with growth factors for the primary outcome 'any limb amputation' as well as for the secondary outcomes 'haemodynamic measures', 'ulceration' and 'rest pain'. The observed heterogeneity in some meta-analyses, especially in the FGF subgroup, may also reflect these biases.

Readers may view the evidence in our review as direct (headto-head comparisons generally applicable for populations and interventions of interest), since only haemodynamic parameters represent somewhat indirect (but validated) measures of blood flow.

The results were generally consistent between the main analyses from studies at low risk of bias and the sensitivity analyses from all studies, between different parameters of outcomes as well as between results based on different effect measures and statistical models. However, inconsistency was relevant for judgment of the results for walking ability.

Imprecision was the major problem for most outcomes since we could not rule out a clinically relevant effect for many primary outcomes or negative effect for some secondary outcomes. Only effect estimates for walking ability were precise enough to exclude a clinically relevant effect.

\section{Potential biases in the review process}

We used a number of strategies to avoid potential biases in the review process. These included an extensive search for relevant published and unpublished trials, the duplication of the trial selection process, 'Risk of bias' assessment and extraction of outcome measures, requests for relevant information from the study authors, resolution of disagreements by consensus and application of different statistical methods in the sensitivity analyses. Despite these efforts, some concern may arise due to multiple counting of any adverse events as a result of their calculation from single events (where aggregate data were lacking), the use of the numbers of participants at baseline for follow-up analyses (if data for the number of participants with measurements were lacking in the publication) and inclusion of the measure 'improvement' (e.g. improvement in ulceration does not consider ulcer development or worsening) in the analysis. In all these cases, our analyses may have overestimated the true effect (increased risk of bias). In addition, as the review is based on only randomised studies, it does not allow for detection of rare adverse events.

\section{Agreements and disagreements with other studies or reviews}

To our knowledge, there is no published systematic review or meta-analysis on the use of growth factors in PAD. Systematic reviews focusing on gene therapy included some of the trials analysed in our review (De Haro 2009; Ghosh 2008; Hammer 2013). In accordance with our review, these analyses did not show a 
clear benefit of growth factors delivered via substances promoting their gene expression in people with PAD. Nevertheless, some relatively recent narrative reviews on therapeutic angiogenesis suggest growth factors are a promising option for people with PAD (Ouma 2012; Pacilli 2010; Powell 2012). However, these reviews did not use rigorous systematic assessment methods to generate conclusive evidence.

\section{AUTHORS' CONCLUSIONS \\ Implications for practice}

The results of this review do not support the use of the therapy with the growth factors FGF, HGF or VEGF in people with PAD of the lower extremities (intermittent claudication or critical limb ischaemia) for preventing death or major limb amputation or for improving walking ability. However, the use of growth factors may improve haemodynamic measures and decrease the rate of any limb amputations (probably due to preventing minor amputations) with an uncertain effect on adverse events; an improvement of ulceration and rest pain is very uncertain. There are no implications for practice on the use of growth factors other than FGF, HGF or VEGF, because we have found no evidence regarding therapy with these substances.

\section{Implications for research}

The evidence on limb amputation, death and adverse events, the main outcomes for decision-making, was imprecise and comes mostly from studies at high or unclear risk of bias (we found only one study at low risk of bias), substantially lowering the quality of evidence of the review. Nevertheless, based on calculated $95 \% \mathrm{Cls}$, we cannot rule out an absolute decline of up to five major limb amputations and up to three deaths per 100 treated patients. To generate evidence with more certainty, new trials at low risk of bias are needed. This possible benefit should be considered with a possible increase of up to seven serious adverse events, and the corresponding trade-off should be estimated. Moreover, highquality clinical trials should evaluate evidence for therapy with growth factors other than FGF, HGF or VEGF.

\section{ACKN O WLEDGEMENTS}

We would like to thank members of Cochrane Vascular for their helpful assistance. We are also very grateful for the financial support of the German Federal Ministry of Education and Research (research grant 01KG1411). 


\section{R E F E R E N C E S}

\section{References to studies included in this review}

Cooper 2001 \{published data only\}

Cooper LT Jr, Hiatt WR, Creager MA, Regensteiner JG, Casscells, Isner W, et al. Proteinuria in a placebo-controlled study of basic fibroblast growth factor for intermittent claudication. Vascular Medicine 2001;6(4):235-9.

\section{Deev 2015 \{published data only\}}

Bozo IY, Deev RV, Plaksa IL, Mzhavanadze ND, Chervyakov YV, Staroverov IN, et al. Long-term results of PCMV-VEGF165 intramuscular gene transfer in patients with chronic lower limb ischemia. Molecular Therapy 2015;23(Suppl 1):S74.

* Deev R, Bozo I, Mzhavanadze N, Voronov D, Gavrilenko A, Chervyakov Y, et al. pCMV-vegf165 intramuscular gene transfer is an effective method of treatment for patients with chronic lower limb ischemia. Journal of Cardiovascular Pharmacology and Therapeutics 2015;20(5):473-82.

\section{HGF-0205 \{published data only\}}

NCT00189540. Study of hepatocyte growth factor (HGF) via plasmid vector to improve perfusion in critical limb ischemia patients with peripheral ischemic ulcers [A phase II doubleblind, randomized, placebo-controlled study to assess the safety and efficacy of AMG0001 to improve perfusion in critical limb ischemia in subjects who have peripheral ischemic ulcers]. clinicaltrials.gov/ct2/show/NCT00189540 (accessed 14 July 2015).

* Powell RJ, Goodney P, Mendelsohn FO, Moen EK, Annex BH, HGF-0205 Trial Investigators. Safety and efficacy of patient specific intramuscular injection of HGF plasmid gene therapy on limb perfusion and wound healing in patients with ischemic lower extremity ulceration: results of the HGF-0205 trial. Journal of Vascular Surgery 2010;52(6):1525-30.

Powell RJ, Marrot P, Annex BH. Safety and efficacy of HGF plasmid gene therapy on limb perfusion and wound healing in patients with ischemic lower extremity ulceration: results of the HGF-0205 trial. Journal of Vascular Surgery 2009;50(2):451.

\section{HGF-STAT \{published data only\}}

NCT00060892. A Phase II Double-Blind, Randomized, PlaceboControlled Study to Assess the Safety and Efficacy of AMG0001 to Improve Perfusion in Critical Leg Ischemia. clinicaltrials.gov/ ct2/show/NCT00060892 (first received 15 May 2003).

Powell RJ. Protocol\#0207-546: a phase I/II, double-blind, randomized, placebo-controlled study to assess the safety and efficacy of AMG0001 to improve perfusion in critical leg ischemia. Human Gene Therapy 2003; Vol. 14, issue 3:302-6. [CRS: 8600100000005337]

Powell RJ, Dormandy J, Simons M, Morishita R, Annex BH. Therapeutic angiogenesis for critical limb ischemia: design of the hepatocyte growth factor therapeutic angiogenesis clinical trial. Vascular Medicine 2004;9(3):193-8.

* Powell RJ, Simons M, Mendelsohn FO, Daniel G, Henry TD, Koga M, et al. Results of a double-blind, placebo-controlled study to assess the safety of intramuscular injection of hepatocyte growth factor plasmid to improve limb perfusion in patients with critical limb ischemia. Circulation 2008;118(1):58-65.

\section{Kibbe 2016 \{published data only\}}

* Kibbe MR, Hirsch AT, Mendelsohn FO, Davies MG, Pham H, Saucedo J, et al. Safety and efficacy of plasmid DNA expressing two isoforms of hepatocyte growth factor in patients with critical limb ischemia. Gene Therapy 2016;23:306-12, 399 (corrigendum).

NCT01064440. Safety and efficacy study using gene therapy for critical limb ischemia. clinicaltrials.gov/ct2/show/ NCT01064440?term=NCT01064440\&rank=1 (first received 4 February 2010).

Perin EC, Mendelsohn F, Davies M, Pham H, Saucedo J, Hirsch A, et al. A phase 2, double-blind, randomized, placebo-controlled, multicenter trial of the safety and efficacy of plasmid DNA expressing 2 isoforms of hepatocyte growth factor in patients with critical limb ischemia. Journal of the American College of Cardiology 2014;63(12):A2092.

\section{Kusumanto 2006 \{published data only\}}

Kusumanto YH, Mulder NH, Dullaart RPF, van den Dungen JJAM, Gans ROB. Phase III comparison of intramuscular delivery of ANG1 (a vascular endothelial growth factor containing plasmid) with placebo in diabetic patients with critical limb ischaemia. Molecular Therapy 2001;3:S73.

* Kusumanto YH, van Weel V, Mulder NH, Smit AJ, van den Dungen JJ, Hooymans JM, et al. Treatment with intramuscular vascular endothelial growth factor gene compared with placebo for patients with diabetes mellitus and critical limb ischemia: a double-blind randomized trial. Human Gene Therapy 2006;17(6):683-91.

\section{Lazarous 2000 \{published data only\}}

Lazarous DF, Unger EF, Epstein SE, Stine A, Arevalo JL, Chew EY, et al. Basic fibroblast growth factor in patients with intermittent claudication: results of a phase I trial. Journal of the American College of Cardiology 2000;36(4):1239-44.

\section{Makinen 2002 \{published data only\}}

* Makinen $\mathrm{K}$, Manninen $\mathrm{H}$, Hedman M, Matsi P, Mussalo $\mathrm{H}$, Alhava $\mathrm{E}$, et al. Increased vascularity detected by digital subtraction angiography after VEGF gene transfer to human lower limb artery: a randomized, placebo-controlled, doubleblinded phase II study. Molecular Therapy 2002;6(1):127-33.

Muona K, Mäkinen K, Hedman M, Manninen H, Yla S. 10-year safety follow-up in patients with local VEGF gene transfer to ischemic lower limb. Herttuala Gene Therapy 2012;19:392-5.

\section{Matyas 2005 \{published data only\}}

Matyas L, Schulte KL, Dormandy JA, Norgren L, Sowade O, Grotzbach $\mathrm{G}$, et al. Arteriogenic gene therapy in patients with unreconstructable critical limb ischemia: a randomized, placebo-controlled clinical trial of adenovirus 5- 
delivered fibroblast growth factor-4. Human Gene Therapy 2005;16(10):1202-11.

\section{NCT00080392 \{published data only\}}

NCT00080392. EW-A-401 to treat intermittent claudication. clinicaltrials.gov/ct2/show/NCT00080392? term=NCT00080392\&rank=1 (first received 30 March 2004).

\section{NCT00304837 \{published data only\}}

NCT00304837. VEGF gene transfer for critical limb ischemia. clinicaltrials.gov/ct2/show/NCT00304837? term=NCT00304837\&rank=1 (first received 16 March 2006).

\section{Rauh 1999 \{published data only\}}

Rauh G, Gravereaux E, Pieczed A, Curry C, Schainfeld R, Isner JM. Assessment of safety and efficiency of intramuscular gene therapy with VEGF-2 in patients with critical limb ischaemia. Circulation 1999;100(Suppl 1):770.

\section{RAVE \{published data only\}}

Rajagopalan S, Mohler III E, Lederman RJ, Saucedo J, Mendelsohn FO, Olin J, et al. Regional angiogenesis with vascular endothelial growth factor (VEGF) in peripheral arterial disease: design of the RAVE trial. American Heart Journal 2003;145(6):1114-8.

* Rajagopalan S, Mohler III ER, Lederman RJ, Mendelsohn FO, Saucedo JF, Goldman CK, et al. Regional angiogenesis with vascular endothelial growth factor in peripheral arterial disease: a phase II randomized, double-blind, controlled study of adenoviral delivery of vascular endothelial growth factor 121 in patients with disabling intermittent claudication. Circulation 2003;108(16):1933-8.

\section{Shigematsu 2010 \{published data only\}}

AnGes MG Inc. Academic release of data from phase III clinical trial of HGF gene therapy conducted in Japan. 2007. www.anges-mg.com/en/news (accessed 4 September 2015).

AnGes MG Inc. Announcement of results of phase III clinical trials of HGF gene therapy in Japan. 2007. www.anges-mg.com/ en/news (accessed 4 September 2015).

* Shigematsu H, Yasuda K, Iwai T, Sasajima T, Ishimaru S, Ohashi Y, et al. Randomized, double-blind, placebo-controlled clinical trial of hepatocyte growth factor plasmid for critical limb ischemia. Gene Therapy 2010;17(9):1152-61.

Yamada E. Report on long-term data of collategene (HGF plasmid) - Japanese phase III study for CLI. 2010. www.angesmg.com/en/news (accessed 4 September 2015).

TALISMAN-201 \{published data only\}

NCT00368797. Efficacy and safety study of NV1FGF in patients with severe peripheral artery occlusive disease (TALISMAN 201). clinicaltrials.gov/ct2/show/NCT00368797? term=NCT00368797\&rank=1 (first received 24 August 2006).

* Nikol S, Baumgartner I, Van Belle E, Diehm C, Visona A, Capogrossi MC, et al. Therapeutic angiogenesis with intramuscular NV1FGF improves amputation-free survival in patients with critical limb ischemia. Molecular Therapy 2008;16(5):972-8.

TALISMAN-202 \{published data only\}

* Henry TD, Mendelsohn F, Comerota A, Pham E, Grek V, Coleman $\mathrm{M}$, et al. Dose and regimen effects of intramuscular NV1FGF in patients with critical limb ischemia: a randomized, double-blind, placebo controlled study. European Heart Journal 2006;27(Suppl 1):Abs P1497.

NCT00798005. Efficacy and safety study of NV1FGF in patients with severe peripheral artery occlusive disease (TALISMAN 202). clinicaltrials.gov/ct2/show/NCT00798005? term=NCT00798005\&rank=1 (first received 24 November 2008).

TALISMAN-211 \{published data only\}

NCT01157871. Dose-finding, safety and efficacy study of NV1FGF in patients with intermittent claudication (TALISMAN 211). clinicaltrials.gov/ct2/show/NCT01157871? term=NCT01157871\&rank=1 (first received 6 July 6 2010).

TAMARIS \{published data only\}

* Belch J, Hiatt WR, Baumgartner I, Driver IV, Nikol S, Norgren L, et al. Effect of fibroblast growth factor NV1FGF on amputation and death: a randomised placebo-controlled trial of gene therapy in critical limb ischaemia. Lancet 2011;377(9781):1929-37.

NCT00566657. Efficacy and safety of XRP0038/NV1FGF in critical limb ischemia patients with skin lesions (TAMARIS). clinicaltrials.gov/ct2/show/NCT00566657? term=NCT00566657\&rank=1 (first received 30 November 2007).

Van Belle E, Nikol S, Norgren L, Baumgartner I, Driver V, Hiatt W, et al. A randomized, double-blind placebo-controlled study of NV1FGF gene therapy in critical limb ischemia patients (TAMARIS Study). Rationale, design and baseline patient characteristics. Archives of Cardiovascular Diseases. Supplements 2011;3:77-8.

Van Belle E, Nikol S, Norgren L, Baumgartner I, Driver V, Hiatt WR, et al. Insights on the role of diabetes and geographic variation in patients with critical limb ischaemia. European Journal of Vascular and Endovascular Surgery 2011;42(3):365-73.

TRAFFIC \{published data only\}

* Lederman RJ, Mendelsohn FO, Anderson RD, Saucedo JF, Tenaglia AN, Hermiller JB, et al. Therapeutic angiogenesis with recombinant fibroblast growth factor- 2 for intermittent claudication (the TRAFFIC study): a randomised trial. Lancet 2002;359(9323):2053-8.

Lederman RJ, Tenaglia AN, Anderson RD, Hermiller JB, RochaSingh K, Mendelsohn FO, et al. Design of the therapeutic angiogenesis with recombinant fibroblast growth factor- 2 for intermittent claudication (TRAFFIC) trial. American Journal of Cardiology 2001;88(2):192-5.

VM202-China \{published data only\}

NCT01548378. Safety and efficacy study using gene therapy for critical limb ischemia (NL003CLI-II). clinicaltrials.gov/ct2/ 
show/NCT01548378?term=NCT01548378\&rank=1 (first received 5 March 2012).

\section{References to studies excluded from this review}

Afshari 2005 \{published data only\}

Afshari M, Larijani B, Fadayee M, Darvishzadeh F, Ghahary A, Pajouhi M, et al. Efficacy of topical epidermal growth factor in healing diabetic foot ulcers. Therapy 2005;2(5):759-65.

\section{Anghel 2011 \{published data only\}}

Anghel A, Taranu G, Seclaman E, Rata A, Tamas L, Moldovan H, et al. Safety of vascular endothelial and hepatocyte growth factor gene therapy in patients with critical limb ischemia. Current Neurovascular Research. 2011; Vol. 8:183-9. [CENTRAL: 811294; CRS: 8600126000002522]

\section{Biggs 2009 \{published data only\}}

Biggs T, Dulas D, Duval S, Goldman J, Henry T, Hirsch A, et al. Hepatocyte growth factor gene therapy for patients with critical limb ischemia: Results of a Phase I dose-escalation trial. Catheterization and Cardiovascular Interventions 2009; Vol. 73, issue S20. [CENTRAL: 793971; CRS: 8600100000008655$]$

\section{$\mathbf{C 0 0 0 0 0 0 3 3 0}$ \{published data only\}}

C000000330. Peripheral blood mononuclear cell therapy in PAD patients with intermittent claudication randomized trial. upload.umin.ac.jp/cgi-open-bin/ctr/ctr.cgi? function=brows\&action=brows\&type=summary\&recptno= (date of disclosure of study information 15 February 2006). [CRS: 8600102000001322]

\section{Capiod 2009 \{published data only\}}

Capiod JC, Tournois C, Vitry F, Sevestre MA, Daliphard S, Reix T, et al. Characterization and comparison of bone marrow and peripheral blood mononuclear cells used for cellular therapy in critical leg ischaemia: towards a new cellular product. Vox Sanguinis 2009; Vol. 96, issue 3:256. [CENTRAL: 747262; CRS: 8600100000008420]

\section{Choi 2012 \{published data only\}}

Choi ET, Geraghty P, Cooke C, Schechtman K, Link D, Chambers CM, et al. Stem cell mobilization to treat severe peripheral artery disease (STEMPAD). 2012 Vascular Annual Meeting 2012. [CENTRAL: 831460; CRS: 8600100000018010]

\section{Creager 2011 \{published data only\}}

Creager MA, Olin JW, Belch JJ, Moneta GL, Henry TD, Rajagopalan S, et al. Effect of hypoxia-inducible factor-1alpha gene therapy on walking performance in patients with intermittent claudication. Circulation 2011; Vol. 124:1765-73. [CENTRAL: 805631; CRS: 8600101000001692$]$

\section{Cui 2015 \{published data only\}}

Cui S, Guo L, Li X, Gu Y, Fu J, Dong L, et al. Clinical safety and preliminary efficacy of plasmid pUDK-HGF expressing human hepatocyte growth factor (HGF) in patients with critical limb ischemia. European Journal of Vascular and Endovascular Surgery 2015;50(4):494-501.

\section{De Leeuw 2008 \{published data only\}}

De Leeuw K, Kusumanto Y, Smit AJ, Oomen P, Van Der Hoeven JH, Mulder NH, et al. Skin capillary permeability in the diabetic foot with critical limb ischaemia: the effects of a phVEGF165 gene product. Diabetic Medicine 2008; Vol. 25, issue 10:1241-4. [CRS: 8600100000008110]

Domanchuk 2013 \{published data only\}

Domanchuk K, Ferrucci L, Guralnik JM, Criqui MH, Tian L, Liu K, et al. Progenitor cell release plus exercise to improve functional performance in peripheral artery disease: the PROPEL study. Contemporary Clinical Trials 2013;36(2):502-9. [CENTRAL: 980378; CRS: 8600131000000034]

Doudar 2013 \{published data only\}

Doudar N, El Ansary M, Abdel Shafy S. Stem cell implantation in the treatment of peripheral vascular disease. Vox Sanguinis 2013; Vol. 105:290. [CENTRAL: 872079; CRS: 8600125000000027]

\section{Fernandez-Montequín 2009 \{published data only\}}

Fernández-Montequín JI, Valenzuela-Silva CM, Díaz OG, Savigne W, Sancho-Soutelo N, Rivero-Fernández F, et al. Intra-lesional injections of recombinant human epidermal growth factor promote granulation and healing in advanced diabetic foot ulcers: multicenter, randomised, placebocontrolled, double-blind study. International Wound Journal 2009;6(6):432-43.

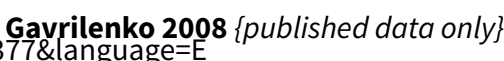

Gavrilenko AV, Voronov DA, Konstantinov BA, Bochkov NP. Combination of reconstructive vascular operations with geneengineering technologies of angiogenesis stimulation: a present-day policy aimed at improving the remote results of treating patients with lower limb chronic ischaemia. Angiologiia I Sosudistaia Khirurgiia [Angiology and Vascular Surgery] 2008; Vol. 14, issue 4:49-53. [CRS: 8600101000001199 ]

\section{Grossman 2007 \{published data only\}}

Grossman PM, Mendelsohn F, Henry TD, Hermiller JB, Litt M, Saucedo, et al. Results from a phase II multicenter, double-blind placebo-controlled study of Del-1 (VLTS-589) for intermittent claudication in subjects with peripheral arterial disease. American Heart Journal 2007; Vol. 153, issue 5:874. [CRS: 8600100000006669]

\section{Huang 2005 \{published data only\}}

Huang P, Li S, Han M, Xiao Z, Yang R, Han ZC. Autologous transplantation of granulocyte colony-stimulating factormobilized peripheral blood mononuclear cells improves critical limb ischemia in diabetes. Diabetes Care 2005; Vol. 28, issue 9:2155. [CRS: 8600100000006254]

\section{Huang 2007 \{published data only\}}

Huang PP, Yang XF, Li SZ, Wen JC, Zhang Y, Han ZC. Randomised comparison of G-CSF-mobilized peripheral blood mononuclear cells versus bone marrow-mononuclear cells for the treatment of patients with lower limb arteriosclerosis obliterans. Thrombosis and Haemostasis 2007; Vol. 98, issue 6:1335-42. [CRS: 8600100000008050] 
JPRN-UMIN000002280 \{published data only\}

JPRN-UMIN000002280. Randomized controlled trial of G-CSFmobilized peripheral blood mononuclear cells transplantation for the treatment of patients with peripheral arterial disease. apps.who.int/trialsearch/Trial2.aspx?TrialID=JPRNUMIN000002280 (date of first enrolment 08 January 2009). [CENTRAL: 983076; CRS: 8600133000000006$]$

\section{Kalka 2000 \{published data only\}}

Kalka C, Masuda H, Takahashi T, Gordon R, Tepper O, Gravereaux E, et al. Vascular endothelial growth factor 165 gene transfer augments circulating endothelial progenitor cells in human subjects. Circulation Research 2000; Vol. 86, issue 12:1198-202. [CRS: 8600100000004520]

Kirana 2012 \{published data only\}

Kirana S, Stratmann B, Prante C, Prohaska W, Koerperich H, Lammers $\mathrm{D}$, et al. Autologous stem cell therapy in the treatment of limb ischaemia induced chronic tissue ulcers of diabetic foot patients. International Journal of Clinical Practice 2012; Vol. 66, issue 4:384-93. [CENTRAL: 830801; CRS: 8600102000000060]

\section{Lasala 2012 \{published data only\}}

* Lasala GP, Silva JA, Minguell JJ. Therapeutic angiogenesis in patients with severe limb ischemia by transplantation of a combination stem cell product. Journal of Thoracic and Cardiovascular Surgery 2012;144(2):377-82.

Lasala GP, Silva JA, Minguell JJ. Therapeutic angiogenesis in patients with severe limb ischemia by transplantation of an autologous bone marrow-derived combination stem cell product. Journal of the American College of Cardiology 2011;57(14 Suppl 1):E2020.

\section{Matoba 2008 \{published data only\}}

Matoba S, Tatsumi T, Murohara T, Imaizumi T, Katsuda Y, Ito M, et al. Long-term clinical outcome after intramuscular implantation of bone marrow mononuclear cells (Therapeutic Angiogenesis by Cell Transplantation [TACT] trial) in patients with chronic limb ischemia. American Heart Journal 2008; Vol. 156, issue 5:1010-8. [CRS: 8600100000007730]

\section{Mohammadzadeh 2013 \{published data only\}}

Mohammadzadeh L, Samedanifard SH, Keshavarzi A, Alimoghaddam K, Larijani B, Ghavamzadeh A, et al. Therapeutic outcomes of transplanting autologous granulocyte colonystimulating factor-mobilised peripheral mononuclear cells in diabetic patients with critical limb ischaemia. Experimental and Clinical Endocrinology \& Diabetes 2013; Vol. 121, issue 1:48-53. [CRS: 8600125000000043]

\section{Mohler 2003 \{published data only\}}

Mohler ER III, Rajagopalan S, Olin JW, Trachtenberg JD, Rasmussen $\mathrm{H}$, Pak R, et al. Adenoviral-mediated gene transfer of vascular endothelial growth factor in critical limb ischemia: safety results from a phase I trial. Vascular Medicine (London) 2003; Vol. 8, issue 1:9-13. [CRS: 8600100000005500 ]

\section{NCT01041417 \{published data only\}}

NCT01041417. Granulocyte-macrophage colony stimulating factor (GM-CSF) and mobilization of progenitor cells in peripheral arterial disease (GPAD-2). //clinicaltrials.gov/ct2/ show/NCT01041417?term=NCT01041417\&rank=1 (first received: 29 December 2009).

\section{NCT01302015 \{published data only\}}

NCT01302015. Autologous adipose tissue derived mesenchymal stem cells transplantation in patient with Buerger's disease. clinicaltrials.gov/ct2/show/NCT01302015? term=NCT01302015\&rank=1 (first received 17 February 2011). [CENTRAL: 983075; CRS: 8600133000000005]

Niebuhr 2012 \{published data only\}

Niebuhr A, Henry T, Goldman J, Baumgartner I, Van Belle E, Gerss J, et al. Long-term safety of intramuscular gene transfer of non-viral FGF1 for peripheral artery disease. Gene Therapy 2012;19(3):264-70. [CRS: 8600126000002424$]$

\section{Olson 2014 \{published data only\}}

Olson E, Demopoulos L, Haws TF, Hu E, Fang Z, Mahar KM, et al. Short-term treatment with a novel HIF-prolyl hydroxylase inhibitor (GSK1278863) failed to improve measures of performance in subjects with claudication-limited peripheral artery disease. Vascular Medicine (London) 2014;19(6):473-82.

\section{Ozturk 2012 \{published data only\}}

Ozturk A, Kucukardali Y, Tangi F, Erikci A, Uzun G, Bashekim C, et al. Therapeutical potential of autologous peripheral blood mononuclear cell transplantation in patients with type 2 diabetic critical limb ischemia. Journal of Diabetes and Its Complications 2012; Vol. 26, issue 1:29-33. [CENTRAL: 831881; CRS: 8600101000001752]

\section{Perin 2011 \{published data only\}}

Perin ECS. A randomized, controlled study of autologous therapy with bone marrow-derived aldehyde dehydrogenase bright cells in patients with critical limb ischemia.

Catheterization and Cardiovascular Interventions 2011; Vol. 78 , issue 7:1060-7. [CRS: 8600101000001591]

\section{Poole 2013 \{published data only\}}

Poole J, Mavromatis K, Binongo JN, Khan A, Li Q, Khayata M, et al. Effect of progenitor cell mobilization with granulocytemacrophage colony-stimulating factor in patients with peripheral artery disease: a randomized clinical trial. JAMA 2013;310(24):2631-9. [CRS: 8600133000000048]

\section{Prochazka 2010 \{published data only\}}

Prochazka V, Gumulec J, Jaluvka F, Salounova D, Jonszta T, Czerny D, et al. Cell therapy, a new standard in management of chronic critical limb ischemia and foot ulcer. Cell Transplantation 2010; Vol. 19, issue 11:1413-24. [CRS: 8600101000001360]

\section{Rajagopalan 2002 \{published data only\}}

Rajagopalan S, Trachtenberg J, Mohler E, Olin J, McBride S, Pak R, et al. Phase I study of direct administration of a replication deficient adenovirus vector containing the vascular endothelial growth factor CDNA (Cl-1023) to patients with claudication. American Journal of Cardiology 2002; Vol. 90, issue 5:512-6. [CRS: 8600100000005299] 
Senet 2011 \{published data only\}

Senet P, Vicaut E, Beneton N, Debure C, Lok C, Chosidow O. Topical treatment of hypertensive leg ulcers with plateletderived growth factor-BB: a randomized controlled trial. Archives of Dermatology 2011;147(8):926-30.

\section{Skora 2015 \{published data only\}}

Skora J, Pupka A, Janczak D, Barc P, Dawiskiba T, Korta K, et al. Combined autologous bone marrow mononuclear cell and gene therapy as the last resort for patients with critical limb ischemia. Archives of Medical Science 2015;11(2):325-31.

\section{Subramaniyam 2009 \{published data only\}}

Subramaniyam V, Waller EK, Murrow JR, Manatunga A, Lonial S, Kasirajan $\mathrm{K}$, et al. Bone marrow mobilization with granulocyte macrophage colony-stimulating factor improves endothelial dysfunction and exercise capacity in patients with peripheral arterial disease. American Heart Journal 2009; Vol. 158, issue 1:53. [CRS: 8600101000003485$]$

Tateishi-Yuyama 2002 \{published data only\}

Tateishi-Yuyama E, Matsubara H, Murohara T, Ikeda U, Shintani S, Masaki H, et al. Therapeutic angiogenesis for patients with limb ischaemia by autologous transplantation of bone-marrow cells: a pilot study and a randomised controlled trial. Lancet 2002; Vol. 360, issue 9331:427. [CRS: 8600100000005197]

\section{Van Royen 2005 \{published data only\}}

Van Royen N, Piek JJ, Legemate DA, Schaper W, Oskam J, Atasever B, et al. Design of the START-trial: STimulation of ARTeriogenesis using subcutaneous application of GM-CSF as a new treatment for peripheral vascular disease. A randomized, double-blind, placebo-controlled trial. Vascular Medicine 2003;8(3):191-6. [CRS: 8600100000005615]

Van Royen N, Schirmer SH, Atasever B, Behrens CYH, Ubbink D, Buschmann EE, et al. A pilot study on STimulation of ARTeriogenesis using subcutaneous application of granulocytemacrophage colony-stimulating factor as a new treatment for peripheral vascular disease. Circulation 2005; Vol. 112, issue 7:1040-6. [CRS: 8600100000006572]

\section{Wang 2014 \{published data only\}}

Wang X, Jiang L, Wang X, Yin F, Li G, Feng X, et al. Combination of autologous transplantation of G-CSF-mobilized peripheral blood mononuclear cells and panax notoginseng saponins in the treatment of unreconstructable critical limb ischemia. Annals of Vascular Surgery 2014;28(6):1501-12.

\section{Wen 2010 \{published data only\}}

Wen J. Autologous peripheral blood mononuclear cells transplantation in treatment of 30 cases of critical limb ischemia: 3-year safety follow-up. Journal of Clinical Rehabilitative Tissue Engineering Research 2010; Vol. 14, issue 45:8526-30. [CENTRAL: 831687; CRS: 8600101000001544]

\section{Yonemitsu 2013 \{published data only\}}

Yonemitsu Y, Matsumoto T, Itoh H, Okazaki J, Uchiyama M, Yoshida K, et al. DVC1-0101 to treat peripheral arterial disease: a phase I/Ila open-label dose-escalation clinical trial. Molecular Therapy 2013;21(3):707-14.

Zafarghandi 2010 \{published data only\}

Zafarghandi MRR, Fazel AP, Baharvand H. Safety and efficacy of granulocytecolony-stimulating factor administration following autologous intramuscular implantation of bone marrow mononuclear cells: a randomized controlled trial in patients with advanced lower limb ischemia. Cytotherapy 2010;12(6):783-91. [CENTRAL: 781692; CRS: 8600101000001383]

\section{References to ongoing studies}

AGILITY \{published data only\}

AnGes MG Inc. AnGes announces amendment to the global development of HGF Plasmid for critical limb ischemia. 2016. www.anges-mg.com/en/news (accessed 27 June 2016).

AnGes MG Inc. AnGes to start global phase III clinical trials of HGF gene therapy for critical limb ischemia in Europe. 2014. www.anges-mg.com/en/news (accessed 4 September 2015).

* NCT02144610. Efficacy and safety of AMG0001 in subjects with critical limb ischemia (AGILITY). clinicaltrials.gov/ct2/show/ NCT02144610?term=NCT02144610\&rank=1 (first received 20 May 2014).

\section{NCT00424866 \{published data only\}}

NCT00424866. FGF-1 for intramuscular injection for the treatment of peripheral arterial disease. clinicaltrials.gov/ct2/ show/NCT00424866?term=NCT00424866\&rank=1 (first received 18 January 2007).

\section{NCT02276937 \{published data only\}}

NCT02276937. Randomized Phase Ilb Trial of DVC1-0101. clinicaltrials.gov/ct2/show/NCT02276937? term=NCT02276937\&rank=1 (first received 22 October 2014).

\section{Additional references}

\section{Balshem 2011}

Balshem H, Helfand M, Schunemann HJ, Oxman AD, Kunz R, Brozek J, et al. GRADE guidelines: 3 . Rating the quality of evidence. Journal of Clinical Epidemiology 2011;64:401-6.

\section{Bedenis 2014}

Bedenis R, Stewart M, Cleanthis M, Robless P, Mikhailidis DP, Stansby G. Cilostazol for intermittent claudication. Cochrane Database of Systematic Reviews 2014, Issue 10. [DOI: 10.1002/14651858.CD003748.pub4]

\section{De Backer 2012}

De Backer TLM, Vander Stichele R, Lehert P, Van Bortel L. Naftidrofuryl for intermittent claudication. Cochrane Database of Systematic Reviews 2012, Issue 12. [DOI: 10.1002/14651858.CD001368.pub4]

\section{De Haro 2009}

De Haro J, Acin F, Lopez-Quintana A, Florez A, MartinezAguilar E, Varela C. Meta-analysis of randomized, controlled 
clinical trials in angiogenesis: gene and cell therapy in peripheral arterial disease. Heart Vessels 2009;24:321-8.

\section{Fowkes 2013}

Fowkes FG, Rudan D, Rudan I, Aboyans V, Denenberg JO, McDermott MM, et al. Comparison of global estimates of prevalence and risk factors for peripheral artery disease in 2000 and 2010: a systematic review and analysis. Lancet 2013;382(9901):1329-40.

\section{Gardner 2008}

Gardner AW, Afaq A. Management of lower extremity peripheral arterial disease. Journal of Cardiopulmonary Rehabilitation and Prevention 2008;28(6):349-57.

\section{Ghosh 2008}

Ghosh R, Walsh SR, Tang TY, Noorani A, Hayes PD. Gene therapy as a novel therapeutic option in the treatment of peripheral vascular disease: systematic review and meta-analysis. International Journal of Clinical Practice 2008;62(9):1383-90.

\section{Hammer 2013}

Hammer A, Steiner S. Gene therapy for therapeutic angiogenesis in peripheral arterial disease - a systematic review and meta-analysis of randomized, controlled trials. Vasa 2013;42(5):331-9.

\section{Higgins 2011}

Higgins JPT, Green S (editors). Cochrane Handbook for Systematic Reviews of Interventions Version 5.1.0 [updated March 2011]. The Cochrane Collaboration, 2011. Available at www.cochrane-handbook.org.

\section{Hirsch 2006}

Hirsch AT, Haskal ZJ, Hertzer NR, Bakal CW, Creager MA, Halperin JL, et al. ACC/AHA 2005 Practice Guidelines for the management of patients with peripheral arterial disease (lower extremity, renal, mesenteric, and abdominal aortic): a collaborative report from the American Association for Vascular Surgery/Society for Vascular Surgery, Society for Cardiovascular Angiography and Interventions, Society for Vascular Medicine and Biology, Society of Interventional Radiology, and the ACC/ AHA Task Force on Practice Guidelines (Writing Committee to Develop Guidelines for the Management of Patients With Peripheral Arterial Disease): endorsed by the American Association of Cardiovascular and Pulmonary Rehabilitation; National Heart, Lung, and Blood Institute; Society for Vascular Nursing; TransAtlantic Inter-Society Consensus; and Vascular Disease Foundation. Circulation 2006;113:e463-e654. [DOI: 10.1161/CIRCULATIONAHA.106.174526]

\section{Lane 2014}

Lane R, Ellis B, Watson L, Leng GC. Exercise for intermittent claudication. Cochrane Database of Systematic Reviews 2014 Issue 7. [DOI: 10.1002/14651858.CD000990.pub3]

\section{Norgren 2007}

Norgren L, Hiatt WR, Dormandy JA, Nehler MR, Harris KA, Fowkes FG. Inter-Society Consensus for the Management of
Peripheral Arterial Disease (TASC II). Journal of Vascular Surgery 2007;45 Suppl S:S5A-S67A.

\section{Ouma 2012}

Ouma GO, Jonas RA, Usman MH, Mohler ER III. Targets and delivery methods for therapeutic angiogenesis in peripheral artery disease. Vascular Medicine 2012;17(3):174-92.

\section{Pacilli 2010}

Pacilli A, Faggioli G, Stella A, Pasquinelli G. An update on therapeutic angiogenesis for peripheral vascular disease. Annals of Vascular Surgery 2010;24(2):258-68.

\section{Powell 2012}

Powell RJ. Update on clinical trials evaluating the effect of biologic therapy in patients with critical limb ischemia. Journal of Vascular Surgery 2012;56(1):264-6.

\section{RevMan 2014 [Computer program]}

The Nordic Cochrane Centre, The Cochrane Collaboration. Review Manager (RevMan). Version 5.3. Copenhagen: The Nordic Cochrane Centre, The Cochrane Collaboration, 2014.

\section{Rooke 2011}

Rooke TW, Hirsch AT, Misra S, Sidawy AN, Beckman JA, Findeiss LK, et al. 2011 ACCF/AHA focused update of the guideline for the management of patients with peripheral artery disease (updating the 2005 guideline): a report of the American College of Cardiology Foundation/American Heart Association Task Force on Practice Guidelines. Circulation 2011;124(18):2020-45

\section{Salhiyyah 2015}

Salhiyyah K, Forster R, Senanayake E, Abdel-Hadi M, Booth A, Michaels JA. Pentoxifylline for intermittent claudication. Cochrane Database of Systematic Reviews 2015, Issue 9. [DOI: 10.1002/14651858.CD005262.pub3]

\section{Tendera 2011}

Tendera M, Aboyans V, Bartelink ML, Baumgartner I, Clement D, Collet JP, et al. ESC Guidelines on the diagnosis and treatment of peripheral artery diseases: document covering atherosclerotic disease of extracranial carotid and vertebral, mesenteric, renal, upper and lower extremity arteries: the Task Force on the Diagnosis and Treatment of Peripheral Artery Diseases of the European Society of Cardiology (ESC). European Heart Journal 2011;32(22):2851-906.

\section{References to other published versions of this review Gorenoi 2015}

Gorenoi V, Brehm MU, Koch A, Hagen A. Growth factors for angiogenesis in peripheral arterial disease. Cochrane Database of Systematic Reviews 2015, Issue 6. [DOI: 10.1002/14651858.CD011741]

* Indicates the major publication for the study 


\section{CHARACTERISTICS OF STUDIES}

\section{Characteristics of included studies [ordered by year of study]}

Rauh 1999

Methods Study design: stated as randomised, placebo-controlled, double-blind trial, dose-escalating trial; randomisation 3:1 (treatment:placebo)

Recruitment: follow-up completed in October 1999 (Boston, USA)

\begin{tabular}{ll}
\hline Participants & People with critical limb ischaemia ( $\mathrm{N}$ randomised and treated = 13) \\
& $\begin{array}{l}\text { Age: no data } \\
\text { Sex (N males/females): no data } \\
\text { Severity: } 6 \text { participants: rest pain alone, } 7 \text { participants: ischaemic ulcers with/without rest pain }\end{array}$ \\
\hline Interventions & VEGF: vascular endothelial growth factor \\
& - VEGF2 (pVGEF2) gene; n randomised not reported \\
& Injections into the ischaemic lower extremity muscles \\
\hline Outcomes & - Ischaemic rest pain \\
- Ischaemic ulcer healing \\
- Complications
\end{tabular}

\section{Risk of bias}

\begin{tabular}{|c|c|c|}
\hline Bias & Authors' judgement & Support for judgement \\
\hline $\begin{array}{l}\text { Random sequence genera- } \\
\text { tion (selection bias) }\end{array}$ & Unclear risk & Procedure is not described \\
\hline $\begin{array}{l}\text { Allocation concealment } \\
\text { (selection bias) }\end{array}$ & Unclear risk & Procedure is not described \\
\hline $\begin{array}{l}\text { Blinding of participants } \\
\text { and personnel (perfor- } \\
\text { mance bias) } \\
\text { All outcomes }\end{array}$ & Unclear risk & Blinding procedure is not explicitly reported \\
\hline $\begin{array}{l}\text { Blinding of outcome as- } \\
\text { sessment (detection bias) } \\
\text { Objective outcomes }\end{array}$ & Low risk & Outcome measurement is not likely to be influenced by lack of blinding \\
\hline $\begin{array}{l}\text { Blinding of outcome as- } \\
\text { sessment (detection bias) } \\
\text { Subjective outcomes }\end{array}$ & Unclear risk & Blinding procedure is not explicitly reported \\
\hline $\begin{array}{l}\text { Incomplete outcome data } \\
\text { (attrition bias) } \\
\text { Death }\end{array}$ & Unclear risk & Results not presented \\
\hline $\begin{array}{l}\text { Incomplete outcome data } \\
\text { (attrition bias) }\end{array}$ & Unclear risk & Results not presented \\
\hline
\end{tabular}


Rauh 1999 (Continued)

Limb amputation

\begin{tabular}{|c|c|c|}
\hline $\begin{array}{l}\text { Incomplete outcome data } \\
\text { (attrition bias) } \\
\text { Ulceration }\end{array}$ & Unclear risk & Results not presented \\
\hline $\begin{array}{l}\text { Incomplete outcome data } \\
\text { (attrition bias) } \\
\text { Rest pain }\end{array}$ & Unclear risk & Results not presented \\
\hline $\begin{array}{l}\text { Incomplete outcome data } \\
\text { (attrition bias) } \\
\text { Walking ability }\end{array}$ & Unclear risk & Results not presented \\
\hline $\begin{array}{l}\text { Incomplete outcome data } \\
\text { (attrition bias) } \\
\text { Haemodynamic measures }\end{array}$ & Unclear risk & Results not presented \\
\hline $\begin{array}{l}\text { Incomplete outcome data } \\
\text { (attrition bias) } \\
\text { Adverse events /severe } \\
\text { complications }\end{array}$ & Unclear risk & Results not presented \\
\hline $\begin{array}{l}\text { Selective reporting (re- } \\
\text { porting bias) }\end{array}$ & High risk & Study completed in October 1999, but results not published \\
\hline Other bias & Unclear risk & Insufficient information to assess whether an important risk of bias exists \\
\hline
\end{tabular}

\section{Lazarous 2000}

Methods Study design: stated as randomised, placebo-controlled, double-blind, phase I trial. Dose-escalation trial: allocation in blocks of 4 (bFGF) vs 2 (placebo) for each dose

Recruitment: no data (Maryland, USA)

\begin{tabular}{ll}
\hline Participants & People with intermittent claudication ( $N$ randomised and treated $=19)$ \\
& Age (mean \pm SD): $68 \pm 10$ years $(b-F G F), 77 \pm 9$ years (placebo) \\
& Sex (N males/females): $6 / 7(46 \% / 54 \%, b-F G F), 4 / 2(67 \% / 33 \%$, placebo) \\
& Severity: ABI (mean \pm SD): $0.60 \pm 0.28(\mathrm{bFGF}), 0.71 \pm 0.34$ (placebo)
\end{tabular}

bFGF: basic fibroblast growth factor (= FGF-2)
\[ \begin{array}{ll}\text { Interventions } & \text { bFGF dose-escalation group }(\mathrm{n}=13) \text {, doses: } \\ & * 1 \times 10 \mu \mathrm{g} / \mathrm{kg} \text { bFGF (day } 1), \mathrm{n}=4 \\ & * 1 \times 30 \mu \mathrm{g} / \mathrm{kg} \text { bFGF (day } 1), \mathrm{n}=5^{\mathrm{a}} \\ & * 2 \times 30 \mu \mathrm{g} / \mathrm{kg} \text { bFGF (days } 1 \text { and } 2), \mathrm{n}=4\end{array} \]

- Placebo $(n=6)$

As intra-arterial infusions over $15 \mathrm{~min}$ in the femoral artery of the more ischaemic leg

$\begin{array}{ll}\text { Outcomes } & \text { Safety (detailed, including retinal photography) through } 1 \text { year } \\ \text { - Calf blood flow (using plethysmography) at } 1 \text { month, at } 6 \text { month } & \text { - Improvement in claudication and walking distances (symptoms) }\end{array}$

Notes

alncl. one patient randomised to $2 \times 30 \mu \mathrm{g} / \mathrm{kg}$ bFGF doses who did not receive the 2 nd dose 


\section{Risk of bias}

\begin{tabular}{lll}
\hline Bias & Authors' judgement & Support for judgement \\
\hline $\begin{array}{l}\text { Random sequence genera- } \\
\text { tion (selection bias) }\end{array}$ & Unclear risk & Procedure is not described \\
\hline $\begin{array}{l}\text { Allocation concealment } \\
\text { (selection bias) }\end{array}$ & Unclear risk & Procedure is not described \\
\hline $\begin{array}{l}\text { Blinding of participants } \\
\text { and personnel (perfor- } \\
\text { mance bias) }\end{array}$ & Unclear risk & Blinding procedure is not explicitly reported \\
$\begin{array}{l}\text { All outcomes } \\
\end{array}$
\end{tabular}

Blinding of outcome as-
sessment (detection bias) $\quad$ Outcome measurement is not likely to be influenced by lack of blinding

ment (detection bias)

Objective outcomes

$\begin{array}{lll}\text { Blinding of outcome as- } & \text { Unclear risk } & \text { Blinding procedure is not explicitly reported } \\ \text { sessment (detection bias) } & \end{array}$

Subjective outcomes

\begin{tabular}{l}
\hline Incomplete outcome data Low risk No missing outcome data \\
(attrition bias) \\
Death
\end{tabular}

Incomplete outcome data Unclear risk $\quad$ Results not explicitly reported
(attrition bias)
Limb amputation

\begin{tabular}{lll}
\hline $\begin{array}{l}\text { Incomplete outcome data } \\
\text { (attrition bias) } \\
\text { Ulceration }\end{array}$ & Unclear risk & The study did not address this outcome \\
\hline $\begin{array}{l}\text { Incomplete outcome data } \\
\text { (attrition bias) } \\
\text { Rest pain }\end{array}$ & Unclear risk & The study did not address this outcome \\
\hline $\begin{array}{l}\text { Incomplete outcome data } \\
\text { (attrition bias) } \\
\text { Walking ability }\end{array}$ & Low risk & $\begin{array}{l}\text { Acceptable reason for missing data (participants treated with } 10 \mu \mathrm{\mu g} / \mathrm{kg} \text { b-FGF } \\
\text { excluded) }\end{array}$ \\
\hline $\begin{array}{l}\text { Incomplete outcome data } \\
\text { (attrition bias) } \\
\text { Haemodynamic measures }\end{array}$ & Low risk & $\begin{array}{l}\text { Acceptable reason for missing data (participants treated with } 10 \mu \mathrm{\mu g} / \mathrm{kg} \mathrm{b}-\mathrm{FGF} \\
\text { excluded) }\end{array}$ \\
\hline
\end{tabular}

\begin{tabular}{|c|c|c|}
\hline $\begin{array}{l}\text { Incomplete outcome data } \\
\text { (attrition bias) } \\
\text { Adverse events /severe } \\
\text { complications }\end{array}$ & Low risk & No missing outcome data (but no aggregate data) \\
\hline $\begin{array}{l}\text { Selective reporting (re- } \\
\text { porting bias) }\end{array}$ & Unclear risk & $\begin{array}{l}\text { The study protocol is not available; results for limb amputation and death not } \\
\text { reported }\end{array}$ \\
\hline Other bias & Low risk & The study appears to be free of other sources of bias \\
\hline
\end{tabular}


Cooper 2001

Study design: stated as randomised, placebo-controlled, double-blind, phase II trial.
Multicentre trial (7 centres), randomisation: 2 (bFGF) vs 1 (placebo)

Recruitment: January 1997 - August 1997 (USA)

\begin{tabular}{ll}
\hline Participants & People with intermittent claudication (N randomised and treated $=24$, plan 108a) \\
& Age (mean \pm SD): $67.1 \pm 7.89$ years $(b F G F)$ vs $69.9 \pm 7.2$ years (placebo) \\
Sex $(N$ males/females): $10 / 4(63 \% / 37 \%, b F G F)$ vs $6 / 2(75 \% / 25 \%$, placebo) \\
Severity: ABI (mean \pm SD): $0.50 \pm 0.1$ (bFGF) vs $0.60 \pm 0.1$ (placebo)
\end{tabular}

\begin{tabular}{ll}
\hline Interventions & bFGF: basic fibroblast growth factor (= FGF-2) \\
& - bFGF: 6 sequential weeks $\times 2 \mu \mathrm{g} / \mathrm{kg}, \mathrm{n}=16$ ( 13 received all 6 doses, 3 received 5 doses) \\
& Placebo, $\mathrm{n}=8$. As intravenous infusions over 4 hours
\end{tabular}

\begin{tabular}{ll}
\hline Outcomes & Peak/total walking time at weeks 4, 8, or 12 (primary) \\
- Time to onset of claudication at weeks 4,8 or 12 \\
- Quality-of-life (SF-36 and walking impairment questionnaire) \\
- Safety (vital signs, adverse events, laboratory studies) \\
\hline Notes \\
ment group; planned dose escalation was not achieved.
\end{tabular}

\section{Risk of bias}

\begin{tabular}{lll}
\hline Bias & Authors' judgement & Support for judgement \\
\hline $\begin{array}{l}\text { Random sequence genera- } \\
\text { tion (selection bias) }\end{array}$ & Unclear risk & Procedure is not described \\
\hline $\begin{array}{l}\text { Allocation concealment } \\
\text { (selection bias) }\end{array}$ & Unclear risk & Procedure is not described \\
\hline $\begin{array}{l}\text { Blinding of participants } \\
\text { and personnel (perfor- } \\
\text { mance bias) } \\
\text { All outcomes }\end{array}$ & Unclear risk & Blinding procedure is not explicitly reported \\
\hline
\end{tabular}

\begin{tabular}{ll}
\hline Blinding of outcome as- & Low risk
\end{tabular} Outcome measurement is not likely to be influenced by lack of blinding

Objective outcomes

\begin{tabular}{ll}
\hline Blinding of outcome as- & Unclear risk
\end{tabular}

Subjective outcomes

Incomplete outcome data Low risk Only 1 patient (in the placebo group) was lost to follow-up
(attrition bias)
Death

\begin{tabular}{lll}
\hline $\begin{array}{l}\text { Incomplete outcome data } \\
\text { (attrition bias) }\end{array}$ & Unclear risk & \\
Limb amputation & \\
\hline $\begin{array}{l}\text { Incomplete outcome data } \\
\text { (attrition bias) }\end{array}$ & Unclear risk & The study did not address this outcome \\
\end{tabular}


Cooper 2001 (Continued)

Ulceration

\begin{tabular}{|c|c|c|}
\hline $\begin{array}{l}\text { Incomplete outcome data } \\
\text { (attrition bias) } \\
\text { Rest pain }\end{array}$ & Unclear risk & The study did not address this outcome \\
\hline $\begin{array}{l}\text { Incomplete outcome data } \\
\text { (attrition bias) } \\
\text { Walking ability }\end{array}$ & Unclear risk & $\mathrm{N}$ of participants with measurements not presented \\
\hline $\begin{array}{l}\text { Incomplete outcome data } \\
\text { (attrition bias) } \\
\text { Haemodynamic measures }\end{array}$ & Unclear risk & $\mathrm{N}$ of participants with measurements not presented \\
\hline $\begin{array}{l}\text { Incomplete outcome data } \\
\text { (attrition bias) } \\
\text { Adverse events /severe } \\
\text { complications }\end{array}$ & Low risk & Only 1 patient was lost to follow-up (no aggregate data) \\
\hline $\begin{array}{l}\text { Selective reporting (re- } \\
\text { porting bias) }\end{array}$ & Unclear risk & The study protocol is not available; results for limb amputation not reported \\
\hline Other bias & Low risk & The study appears to be free of other sources of bias \\
\hline
\end{tabular}

\section{TRAFFIC}

Study design: stated as randomised, placebo-controlled, double-blind, phase II trial.
Multicentre trial (different hospitals), randomisation code: $1: 1: 1$

Multicentre trial (different hospitals), randomisation code: 1:1:1

Recruitment: no data (USA)

\begin{tabular}{ll}
\hline Participants & People with moderate-to-severe intermittent claudication ( $\mathrm{N}$ randomised and received first dose $=190$, \\
& planned $N=180$ ) \\
& Age (mean): 67 years (placebo), 65 years (single-dose), 69 years (double-dose) \\
& Sex ( $N$ males/females): $73 \% / 27 \%$ (placebo), $71 \% / 29 \%$ (single-dose), $82 \% / 18 \%$ (double-dose)
\end{tabular}

Severity: $A B I$ : in all groups mean levels between 0.5 and 0.6 (data from figure)

Interventions
$\begin{aligned} & \text { FGF-2: recombinant fibroblast growth factor- } 2 \\ & . \\ & \text { - } 2 \times 30 \mu \mathrm{g} / \mathrm{kg} \text { FGF-2 (days } 1 \text { and } 30 \text { ); } 61 \text { participants received } 1 \text { dose, } 53 \text { all doses } \\ & \text { - } 2 \times \text { placebo (days } 1 \text { and } 30 \text { ); } 63 \text { participants received } 1 \text { dose, } 60 \text { all doses }\end{aligned}$

As 2 intra-arterial infusions (15 $\mu \mathrm{g} / \mathrm{kg}$ FGF-2 per limb), each over 10 minutes

\begin{tabular}{ll}
\hline Outcomes & - Change in peak walking time from baseline to 90 days (primarya), \\
- Peak walking time change from baseline to 180 days \\
- Claudication onset time and $\mathrm{ABI}$ change from baseline to 90 and 180 days \\
- Quality-of-life change from baseline to 30,90 , and 180 days \\
\hline Notes & adifference between 3 groups based on analysis of variance
\end{tabular}

\section{Risk of bias}


TRAFFIC (Continued)

\begin{tabular}{lll} 
Bias & Authors' judgement & Support for judgement \\
\hline $\begin{array}{l}\text { Random sequence genera- } \\
\text { tion (selection bias) }\end{array}$ & Low risk & Randomisation codes were generated \\
\hline $\begin{array}{l}\text { Allocation concealment } \\
\text { (selection bias) }\end{array}$ & Low risk & Allocation by sequentially opening sealed assignment envelopes \\
\hline $\begin{array}{l}\text { Blinding of participants } \\
\begin{array}{l}\text { and personnel (perfor- } \\
\text { mance bias) }\end{array}\end{array}$ & Unclear risk & Blinding procedure is not explicitly reported \\
All outcomes & \\
\hline
\end{tabular}

\begin{tabular}{ll}
\hline Blinding of outcome as- & Low risk
\end{tabular} Outcome measurement is not likely to be influenced by lack of blinding

Objective outcomes

\begin{tabular}{|c|c|c|}
\hline $\begin{array}{l}\text { Blinding of outcome as- } \\
\text { sessment (detection bias) } \\
\text { Subjective outcomes }\end{array}$ & Unclear risk & Blinding procedure is not explicitly reported \\
\hline $\begin{array}{l}\text { Incomplete outcome data } \\
\text { (attrition bias) } \\
\text { Death }\end{array}$ & Low risk & $\begin{array}{l}\text { Only few missing data, which are balanced in numbers across intervention } \\
\text { groups }\end{array}$ \\
\hline $\begin{array}{l}\text { Incomplete outcome data } \\
\text { (attrition bias) } \\
\text { Limb amputation }\end{array}$ & Unclear risk & Results not explicitly reported \\
\hline $\begin{array}{l}\text { Incomplete outcome data } \\
\text { (attrition bias) } \\
\text { Ulceration }\end{array}$ & Unclear risk & The study did not address this outcome \\
\hline $\begin{array}{l}\text { Incomplete outcome data } \\
\text { (attrition bias) } \\
\text { Rest pain }\end{array}$ & Unclear risk & The study did not address this outcome \\
\hline $\begin{array}{l}\text { Incomplete outcome data } \\
\text { (attrition bias) } \\
\text { Walking ability }\end{array}$ & Low risk & $\begin{array}{l}\mathrm{N} \text { missing data are low }(<15 \%) \text {. Reasons for missing are reported and balanced } \\
\text { across groups }\end{array}$ \\
\hline $\begin{array}{l}\text { Incomplete outcome data } \\
\text { (attrition bias) } \\
\text { Haemodynamic measures }\end{array}$ & Low risk & $\begin{array}{l}\mathrm{N} \text { missing data are low }(<15 \%) \text {. Reasons for missing are reported and balanced } \\
\text { across groups }\end{array}$ \\
\hline $\begin{array}{l}\text { Incomplete outcome data } \\
\text { (attrition bias) } \\
\text { Adverse events /severe } \\
\text { complications }\end{array}$ & Low risk & Only few missing data (no aggregate data) \\
\hline $\begin{array}{l}\text { Selective reporting (re- } \\
\text { porting bias) }\end{array}$ & Unclear risk & The study protocol is not available, results for limb amputation not reported \\
\hline Other bias & Low risk & The study appears to be free of other sources of bias \\
\hline
\end{tabular}


Makinen 2002

\begin{tabular}{|c|c|}
\hline Methods & $\begin{array}{l}\text { Study design: stated as randomised, placebo-controlled, double-blind, phase II trial } \\
\text { Recruitment: no data (Kuopio, Finland) }\end{array}$ \\
\hline Participants & $\begin{array}{l}\text { People with chronic lower-limb ischaemia and atherosclerotic infrainguinal occlusion or stenosis suit- } \\
\text { able for PTA ( } \mathrm{N} \text { randomised and received treatment = 54) } \\
\text { Age (mean): } 73 \text { years (control), } 74 \text { (VEGF-P/L), } 70 \text { years (VEGF-AdV) } \\
\text { Sex (N males/females): } 8 / 11 \text { (control), } 6 / 11 \text { (VEGF-P/L), } 9 / 9 \text { (VEGF-AdV) } \\
\text { Severity: claudication/critical limb ischaemia: } 15 / 4 \text { (control), } 11 / 6 \text { (VEGF-P/L), 14/4 (VEGF-AdV) }\end{array}$ \\
\hline Interventions & $\begin{array}{l}\text { VEGF: vascular endothelial growth factor } \\
\text { - VEGF-Ad (VEGF-adenovirus; } 2 \times 10^{10} \text { plaque-forming units); } \mathrm{n}=18 \\
\text { - VEGF-P/L (VEGF-plasmid/liposome; } 2000 \mu \mathrm{g} \text { of VEGF plasmid, } 2000 \mu \mathrm{L} \text { of DOTMA:DOPE); } \mathrm{n}=17 \\
\text { - Control ( } 1000 \mu \mathrm{L} \text { Ringer's lactate solution); } \mathrm{n}=19 \\
\text { All after PTA during a 10-minute infusion using a coil-balloon or a channeled-balloon catheter }\end{array}$ \\
\hline Outcomes & $\begin{array}{l}\text { - Vascularity (measured by digital subtraction angiography; primary outcome) } \\
\text { - Clinical response, ankle-brachial index (ABI) at } 3 \text { months' follow-up; amputations, Fontaine classifi- } \\
\text { cation (n participants at each class) at } 10 \text { years' follow-up } \\
\text { - Safety: major procedural complications, deaths, new cancers at } 24 \text { months' follow-up; deaths, cancer, } \\
\text { diabetes, retinopathy at } 10 \text { years' follow-up. }\end{array}$ \\
\hline
\end{tabular}

Notes

The trial originally aimed to recruit 20 participants per group, but 6 participants were excluded (lastminute laboratory results and signs of acute infection or cancelled participation just before the operation)

\section{Risk of bias}

\begin{tabular}{|c|c|c|}
\hline Bias & Authors' judgement & Support for judgement \\
\hline $\begin{array}{l}\text { Random sequence genera- } \\
\text { tion (selection bias) }\end{array}$ & Low risk & Procedure based on random digits \\
\hline $\begin{array}{l}\text { Allocation concealment } \\
\text { (selection bias) }\end{array}$ & Unclear risk & Procedure is not described \\
\hline $\begin{array}{l}\text { Blinding of participants } \\
\text { and personnel (perfor- } \\
\text { mance bias) } \\
\text { All outcomes }\end{array}$ & Low risk & $\begin{array}{l}\text { The treatment and original follow-up for } 3 \text { months were made in a dou- } \\
\text { ble-blinded manner }\end{array}$ \\
\hline $\begin{array}{l}\text { Blinding of outcome as- } \\
\text { sessment (detection bias) } \\
\text { Objective outcomes }\end{array}$ & Low risk & Outcome measurement is not likely to be influenced by lack of blinding \\
\hline $\begin{array}{l}\text { Blinding of outcome as- } \\
\text { sessment (detection bias) } \\
\text { Subjective outcomes }\end{array}$ & Low risk & $\begin{array}{l}\text { The treatment and original follow-up for } 3 \text { months were made in a dou- } \\
\text { ble-blinded manner }\end{array}$ \\
\hline $\begin{array}{l}\text { Incomplete outcome data } \\
\text { (attrition bias) } \\
\text { Death }\end{array}$ & Low risk & No missing data at 3 months; $<10 \%$ missing data at 10 years \\
\hline $\begin{array}{l}\text { Incomplete outcome data } \\
\text { (attrition bias) } \\
\text { Limb amputation }\end{array}$ & Low risk & Probably no missing data at 3 months; $<10 \%$ missing data at 10 years \\
\hline
\end{tabular}


Makinen 2002 (Continued)

Incomplete outcome data High risk Results only for subgroup of CLI participants (24\%)

(attrition bias)

Ulceration

Incomplete outcome data High risk Results only for subgroup of CLI participants (24\%)
(attrition bias)
Rest pain

\begin{tabular}{|c|c|c|}
\hline $\begin{array}{l}\text { Incomplete outcome data } \\
\text { (attrition bias) } \\
\text { Walking ability }\end{array}$ & Unclear risk & The study did not address this outcome \\
\hline $\begin{array}{l}\text { Incomplete outcome data } \\
\text { (attrition bias) } \\
\text { Haemodynamic measures }\end{array}$ & Unclear risk & $\mathrm{N}$ of participants with measurements not reported \\
\hline $\begin{array}{l}\text { Incomplete outcome data } \\
\text { (attrition bias) } \\
\text { Adverse events /severe } \\
\text { complications }\end{array}$ & Low risk & $\begin{array}{l}\text { No missing data at } 3 \text { months; }<10 \% \text { missing data at } 10 \text { years (no aggregate da- } \\
\text { ta) }\end{array}$ \\
\hline $\begin{array}{l}\text { Selective reporting (re- } \\
\text { porting bias) }\end{array}$ & Low risk & $\begin{array}{l}\text { The study protocol is not available, but results for all relevant outcomes are } \\
\text { provided }\end{array}$ \\
\hline Other bias & Low risk & The study appears to be free of other sources of bias \\
\hline
\end{tabular}

RAVE

Methods Study design: stated as randomised, placebo-controlled, double-blind, phase II trial. Randomisation $1: 1: 1$

Recruitment: no data (USA)

\begin{tabular}{ll}
\hline Participants & People with unilateral exercise-limiting intermittent claudication (N randomised and received treat- \\
& ment = 105) \\
& Age (mean): 68 years (control), 66 (low-dose), 64 years (high-dose) \\
& Sex (N males/females): $91 \% / 9 \%$ (control), $81 \% / 19 \%$ (low-dose), 67\%/33\% (high-dose)
\end{tabular}

Severity: ABI (index leg): 0.6 (placebo), 0.6 (low-dose), 0.6 (high-dose)

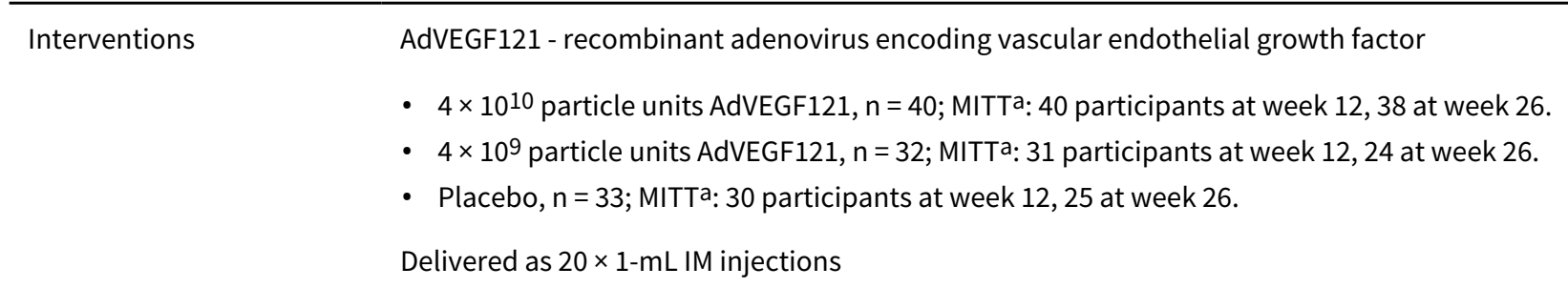

- Change in peak walking time to week 12 (primary), to week 26
- Change in claudication onset time to week 12 , to week 26
- Ankle-brachial index (ABI) at 12 weeks, at 26 weeks
- Quality of life measures at 12 weeks, at 26 weeks

Notes

ITT analysis: missing data analysed using the last observation carried forward procedure. Peak walking time and claudication onset time recorded as 0 after mechanical intervention (revascularisation) or inability to walk on the treadmill 
RAVE (Continued)

aModified ITT (MITT) analysis: missing data and data collected after revascularisation or treatment with cilostazol were excluded

\section{Risk of bias}

\begin{tabular}{lll}
\hline Bias & Authors' judgement & Support for judgement \\
\hline $\begin{array}{l}\text { Random sequence genera- } \\
\text { tion (selection bias) }\end{array}$ & Unclear risk & Procedure is not reported \\
\hline $\begin{array}{l}\text { Allocation concealment } \\
\text { (selection bias) }\end{array}$ & Unclear risk & Procedure is not reported \\
\hline
\end{tabular}

Blinding of participants Unclear risk Blinding procedure is not explicitly reported
and personnel (perfor-
mance bias)
All outcomes

Blinding of outcome as- Low risk Outcome measurement is not likely to be influenced by lack of blinding
sessment (detection bias)

Objective outcomes

\begin{tabular}{|c|c|c|}
\hline $\begin{array}{l}\text { Blinding of outcome as- } \\
\text { sessment (detection bias) } \\
\text { Subjective outcomes }\end{array}$ & Unclear risk & Blinding procedure is not explicitly reported \\
\hline $\begin{array}{l}\text { Incomplete outcome data } \\
\text { (attrition bias) } \\
\text { Death }\end{array}$ & Low risk & Data for almost all participants \\
\hline $\begin{array}{l}\text { Incomplete outcome data } \\
\text { (attrition bias) } \\
\text { Limb amputation }\end{array}$ & Low risk & Data for almost all participants \\
\hline $\begin{array}{l}\text { Incomplete outcome data } \\
\text { (attrition bias) } \\
\text { Ulceration }\end{array}$ & Unclear risk & The study did not address this outcome \\
\hline $\begin{array}{l}\text { Incomplete outcome data } \\
\text { (attrition bias) } \\
\text { Rest pain }\end{array}$ & Unclear risk & The study did not address this outcome \\
\hline $\begin{array}{l}\text { Incomplete outcome data } \\
\text { (attrition bias) } \\
\text { Walking ability }\end{array}$ & Low risk & $\begin{array}{l}\mathrm{N} \text { missing data at week } 12 \text { low }(<5 \%) \text {, at week } 26 \text { higher }(<20 \%) \text {; results are } \\
\text { not likely to be influenced. }\end{array}$ \\
\hline $\begin{array}{l}\text { Incomplete outcome data } \\
\text { (attrition bias) } \\
\text { Haemodynamic measures }\end{array}$ & Unclear risk & No data for number of participants with measurements \\
\hline $\begin{array}{l}\text { Incomplete outcome data } \\
\text { (attrition bias) } \\
\text { Adverse events /severe } \\
\text { complications }\end{array}$ & Low risk & Data for almost all participants (no aggregate data) \\
\hline $\begin{array}{l}\text { Selective reporting (re- } \\
\text { porting bias) }\end{array}$ & Low risk & $\begin{array}{l}\text { The study protocol is not available, but results for all relevant outcomes are } \\
\text { provided }\end{array}$ \\
\hline
\end{tabular}


RAVE (Continued)
Other bias
Low risk
The study appears to be free of other sources of bias

Matyas 2005

Methods Study design: stated as randomised, placebo-controlled, double-blind, dose-escalation trial Multicentre trial (6 centres); allocation: 3 (Ad5FGF-4) vs 1 (placebo)

Recruitment: no data (Europe)

Participants

People with critical limb ischaemia who had no option for revascularisation ( $\mathrm{N}$ randomised and treated $=13^{\mathrm{a}}$, plan 28)

Age (mean): 65 years (Ad5FGF-4) vs 60 years (placebo)

Sex (N males/females): 6/4 (Ad5FGF-4) vs 2/1 (placebo)

Severity: Fontaine stage IV: 6 of 10 (Ad5FGF-4) vs 1 of 3 (placebo)

\begin{tabular}{ll}
\hline Interventions & Ad5FGF-4: adenovirus-delivered fibroblast growth factor-4, $\mathrm{n}=10$ \\
& $* 2.87 \times 10^{8}$ viral particles Ad5FGF-4, $\mathrm{n}=5$ a \\
& $* 2.87 \times 10^{9}$ viral particles Ad5FGF-4, $\mathrm{n}=3$ \\
& $* 2.87 \times 10^{10}$ viral particles Ad5FGF-4, $\mathrm{n}=2$ \\
& - Placebo solution, $\mathrm{n}=3$ \\
& As 8 intramuscular injections given pairwise \\
\hline Outcomes & - Safety up to 12 weeks \\
\hline
\end{tabular}

$\begin{array}{ll}\text { Notes } & \text { a2 participants from separate but comparable protocols } \\ \text { Enrollment was terminated because of slow recruitment }\end{array}$

\section{Risk of bias}

\begin{tabular}{lll}
\hline Bias & Authors' judgement & Support for judgement \\
\hline $\begin{array}{l}\text { Random sequence genera- } \\
\text { tion (selection bias) }\end{array}$ & Unclear risk & Procedure not reported \\
\hline $\begin{array}{l}\text { Allocation concealment } \\
\text { (selection bias) }\end{array}$ & Unclear risk & Procedure not reported \\
\hline $\begin{array}{l}\text { Blinding of participants } \\
\begin{array}{l}\text { and personnel (perfor- } \\
\text { mance bias) } \\
\text { All outcomes }\end{array}\end{array}$ & Low risk & Participants and investigators remained double blinded throughout the trial \\
\hline
\end{tabular}

\begin{tabular}{lll}
\hline $\begin{array}{l}\text { Blinding of outcome as- } \\
\text { sessment (detection bias) } \\
\text { Objective outcomes }\end{array}$ & Low risk & Outcome measurement is not likely to be influenced by lack of blinding \\
\hline $\begin{array}{l}\text { Blinding of outcome as- } \\
\text { sessment (detection bias) } \\
\text { Subjective outcomes }\end{array}$ & Low risk & Participants and investigators remained double blinded throughout the trial \\
\hline
\end{tabular}

Incomplete outcome data Low risk Events for each patient reported

(attrition bias) 
Matyas 2005 (Continued)

Death

\begin{tabular}{|c|c|c|}
\hline $\begin{array}{l}\text { Incomplete outcome data } \\
\text { (attrition bias) } \\
\text { Limb amputation }\end{array}$ & Low risk & Events for each patient reported \\
\hline $\begin{array}{l}\text { Incomplete outcome data } \\
\text { (attrition bias) } \\
\text { Ulceration }\end{array}$ & Low risk & Levels for each patient reported \\
\hline $\begin{array}{l}\text { Incomplete outcome data } \\
\text { (attrition bias) } \\
\text { Rest pain }\end{array}$ & Low risk & Levels for each patient reported \\
\hline
\end{tabular}

\begin{tabular}{|c|c|c|}
\hline $\begin{array}{l}\text { Incomplete outcome data } \\
\text { (attrition bias) }\end{array}$ & Unclear risk & The study did not address this outcome \\
\hline
\end{tabular}

Walking ability

\begin{tabular}{lll}
\hline $\begin{array}{l}\text { Incomplete outcome data } \\
\text { (attrition bias) } \\
\text { Haemodynamic measures }\end{array}$ & Low risk & Levels for each patient reported \\
\hline $\begin{array}{l}\text { Incomplete outcome data } \\
\text { (attrition bias) } \\
\begin{array}{l}\text { Adverse events /severe } \\
\text { complications }\end{array}\end{array}$ & Low risk & Data for all participants (no aggregate data for study groups presented) \\
\hline $\begin{array}{l}\text { Selective reporting (re- } \\
\text { porting bias) }\end{array}$ & Low risk & The study protocol is not available, but reporting bias is not expected \\
\hline \begin{tabular}{l} 
Other bias \\
\hline
\end{tabular} & Low risk & The study appears to be free of other sources of bias \\
\hline
\end{tabular}

Kusumanto 2006

\begin{tabular}{|c|c|}
\hline Methods & $\begin{array}{l}\text { Study design: stated as randomised, placebo-controlled, double-blind trial } \\
\text { 2-centre trial. Randomisation: computerised block } \\
\text { Recruitment: February } 2000 \text { - January } 2004 \text { (Netherlands) }\end{array}$ \\
\hline Participants & $\begin{array}{l}\text { Adult diabetic people with critical limb ischaemia ( } \mathrm{N} \text { randomised and treated }=54 \text {, plan } 54 \text { ) } \\
\text { Age (mean): } 69 \text { years (phVEGF165) vs } 68 \text { years (placebo) } \\
\text { Sex (N males/females): } 16 / 11 \text { (phVEGF165) vs } 15 / 12 \text { (placebo) } \\
\text { Severity: } n \text { ulcer/pain: } 21 / 24 \text { of } 27 \text { (phVEGF165) vs } 17 / 23 \text { of } 27 \text { (placebo) }\end{array}$ \\
\hline Interventions & $\begin{array}{l}\text { phVEGF165: plasmid carrying the human VEGF165 gene } \\
\text { - } 2 \times 2000 \mu \mathrm{g} \text { phVEGF165, IM; } \mathrm{n}=27 \\
\text { - } 2 \times \text { Placebo }(0.9 \% \mathrm{NaCl}), \mathrm{IM} ; \mathrm{n}=27 \\
\text { As } 4 \text { aliquots, each containing } 500 \mu \mathrm{g} \text { of phVEGF165 }\end{array}$ \\
\hline Outcomes & $\begin{array}{l}\text { - Amputation rate at } 100 \text { days (primary), } \\
\text { - Safety (incl. death), limb survival, response } \\
\text { - Improvement in skin ulcer, pain at } 100 \text { days } \\
\text { - Haemodynamic improvement at } 100 \text { days }\end{array}$ \\
\hline
\end{tabular}


Kusumanto 2006 (Continued)

- Improvement in quality of life at 100 daysa

Notes aResults reported only descriptively

\section{Risk of bias}

\begin{tabular}{lll}
\hline Bias & Authors' judgement & Support for judgement \\
\hline $\begin{array}{l}\text { Random sequence genera- } \\
\text { tion (selection bias) }\end{array}$ & Low risk & Computerised block randomisation \\
\hline $\begin{array}{l}\text { Allocation concealment } \\
\text { (selection bias) }\end{array}$ & Low risk & Central randomisation \\
\hline
\end{tabular}

Blinding of participants Unclear risk Blinding procedure reported for providers but not participants
and personnel (perfor-
mance bias)
All outcomes

\begin{tabular}{ll}
\hline Blinding of outcome as- & Low risk \\
sessment (detection bias)
\end{tabular}

Objective outcomes

\begin{tabular}{lll}
\hline Blinding of outcome as- & Unclear risk & Blinding procedure is not explicitly reported \\
sessment (detection bias) & \\
Subjective outcomes & \\
\hline
\end{tabular}

Incomplete outcome data Low risk Data for all participants
(attrition bias)
Death

Incomplete outcome data Low risk Data for all participants
(attrition bias)
Limb amputation

Incomplete outcome data High risk $\quad$ Results only for subgroup of participants (70\%) with ulcer at baseline
(attrition bias)

Ulceration

Incomplete outcome data High risk Data missing for approx. 40\% of treated participants
(attrition bias)
Rest pain

\begin{tabular}{ll}
\hline $\begin{array}{l}\text { Incomplete outcome data } \\
\text { (attrition bias) }\end{array}$ & The study did not address this outcome \\
Walking ability & Data missing for approx. 30\% of all treated participants (not evaluable) \\
\hline $\begin{array}{l}\text { Incomplete outcome data } \\
\text { (attrition bias) } \\
\text { Haemodynamic measures }\end{array}$ & Digh risk \\
$\begin{array}{l}\text { Incomplete outcome data } \\
\text { (attrition bias) }\end{array}$ & Low risk \\
$\begin{array}{l}\text { Adverse events /severe } \\
\text { complications }\end{array}$ &
\end{tabular}

Selective reporting (re- Low risk The study protocol is not available, but reporting bias is not expected
porting bias)


Kusumanto 2006 (Continued)
Other bias
Low risk
The study appears to be free of other sources of bias

\section{HGF-STAT}

Methods Study design: stated as randomised, placebo-controlled, double-blind, phase II trial.

Dose-response study

Recruitment: April 2003 - January 2007 (20 centres in USA)

\begin{tabular}{|c|c|}
\hline Participants & $\begin{array}{l}\text { People with critical limb ischaemia (with rest pain or ischaemic ulcers) who were poor candidates for } \\
\text { standard revascularisation treatment } \\
\text { ( } \mathrm{N} \text { randomised = } 106 \text { participants, } 104 \text { received at least } 1 \text { dose of study drug) } \\
\text { Age (mean): } 70 \text { years (placebo), } 70 \text { years (low-dose), } 73 \text { years (middle-dose), } 68 \text { years (high-dose) } \\
\text { Sex ( } \mathrm{N} \text { males/females): } 63 \% / 37 \% \text { (placebo), } 76 \% / 24 \% \text { (low-dose), } 57 \% / 43 \% \text { (middle-dose), 57\%/43\% } \\
\text { (high-dose) } \\
\text { Severity: mean total ulcer size ( } \mathrm{cm}^{2} \text { ): } 3.6 \text { (placebo), } 3.7 \text { (low-dose), } 5.8 \text { (middle-dose), } 3.2 \text { (high-dose) }\end{array}$ \\
\hline Interventions & 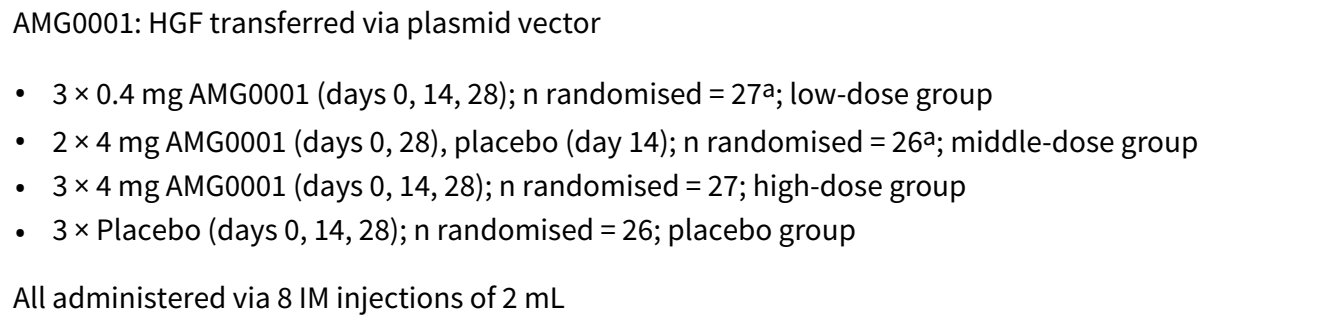 \\
\hline
\end{tabular}

Outcomes

- $\mathrm{tcpO}_{2}$ through 6 months (at 6 months - primaryb)

- Ulcer healing through 6 months

- Safety through 12 months

- $\mathrm{ABI}, \mathrm{TBI}$ through 6 months

- Other (amputation, mortality, pain, quality of life) through 6 months

\begin{tabular}{|c|c|}
\hline Notes & $\begin{array}{l}\text { a } 1 \text { participant did not receive at least } 1 \text { dose. } \\
\text { bParticipants with }>15 \mathrm{~mm} \mathrm{Hg} \text { increase in tcpO } \mathrm{O}_{2} \text { from screening to baseline (i.e. before the first set of } \\
\text { injections) were excluded }\end{array}$ \\
\hline
\end{tabular}

\section{Risk of bias}

\begin{tabular}{lll}
\hline Bias & Authors' judgement & Support for judgement \\
\hline $\begin{array}{l}\text { Random sequence genera- } \\
\text { tion (selection bias) }\end{array}$ & Unclear risk & Procedure is not explicitly reported \\
\hline $\begin{array}{l}\text { Allocation concealment } \\
\text { (selection bias) }\end{array}$ & Unclear risk & Procedure is not explicitly reported \\
\hline $\begin{array}{l}\text { Blinding of participants } \\
\text { and personnel (perfor- } \\
\text { mance bias) }\end{array}$ & Unclear risk & Blinding procedure is not explicitly reported \\
All outcomes & \\
\hline
\end{tabular}

$\begin{aligned} & \text { Blinding of outcome as- } \\ & \text { sessment (detection bias) }\end{aligned} \quad$ Low risk Outcome measurement is not likely to be influenced by lack of blinding


HGF-STAT (Continued)

Objective outcomes

\begin{tabular}{lll}
$\begin{array}{l}\text { Blinding of outcome as- } \\
\text { sessment (detection bias) } \\
\text { Subjective outcomes }\end{array}$ & Unclear risk & Blinding procedure is not explicitly reported \\
\hline $\begin{array}{l}\text { Incomplete outcome data } \\
\begin{array}{l}\text { (attrition bias) } \\
\text { Death }\end{array}\end{array}$ & Low risk & Data for only 2 of 106 randomised subjects are missing \\
\hline
\end{tabular}

Death

Incomplete outcome data Unclear risk Number of participants with event not presented

(attrition bias)

Limb amputation

Incomplete outcome data High risk Based on data for only 50 of 106 randomised participants $(<50 \%)$
(attrition bias)
Ulceration

\begin{tabular}{|c|c|c|}
\hline $\begin{array}{l}\text { Incomplete outcome data } \\
\text { (attrition bias) } \\
\text { Rest pain }\end{array}$ & Unclear risk & Results not presented \\
\hline $\begin{array}{l}\text { Incomplete outcome data } \\
\text { (attrition bias) } \\
\text { Walking ability }\end{array}$ & Unclear risk & The study did not address this outcome \\
\hline $\begin{array}{l}\text { Incomplete outcome data } \\
\text { (attrition bias) } \\
\text { Haemodynamic measures }\end{array}$ & High risk & Based on data for only 71 of 106 randomised participants (70\%) \\
\hline $\begin{array}{l}\text { Incomplete outcome data } \\
\text { (attrition bias) } \\
\text { Adverse events /severe } \\
\text { complications }\end{array}$ & Low risk & Data for only 2 of 106 randomised participants are missing \\
\hline $\begin{array}{l}\text { Selective reporting (re- } \\
\text { porting bias) }\end{array}$ & Unclear risk & Presented results for limb amputations, $\mathrm{ABI}, \mathrm{TBI}$ and pain relief are insufficient \\
\hline Other bias & Low risk & The study appears to be free of other sources of bias \\
\hline
\end{tabular}

\section{TALISMAN-201}

Methods Study design: stated as randomised, placebo-controlled, double-blind, phase II trial.

Multicentre trial (clinics in 6 European countries), block randomisation.

Recruitment: April 2002 - April 2004. Completion date: April 2005

Participants People with critical limb ischaemia, all with nonhealing ulcer, who were poor or not candidates for
revascularisation

$(\mathrm{N}$ randomised $=125$, received at least one injection $=118, \mathrm{MITTa}=107)$

Age (mean $\pm \mathrm{SD}): 73.3 \pm 9.8$ years (placebo), $71.1 \pm 10.4$ years (NV1FGF)

Sex (N males/females): 42/14 (75\%/25\%, placebo) vs 33/18 (65\%/35\%, NV1FGF)

Severity: N ulcers per participant (mean (range)): 2.0 (1-5, placebo) vs 1.8 (1-6, NV1FGF)

Ulcers aggregate size ( $\mathrm{cm}^{2}$, mean): 21.8 (placebo) vs 21.7 (NV1FGF) 
TALISMAN-201 (Continued)

Interventions

NV1FGF: non-viral 1 fibroblast growth factor

- $4 \times 4$ mg NV1FGF ( $n$ randomised $=59$, received at least 1 injection $=57$, MITTa $=51$ )

- $4 \times$ Placebo $(\mathrm{n}$ randomised $=66$, received at least 1 injection $=61$, MITTa $=56$ )

Sessions on days 1, 15, 30 and 45 of each 8 IM $2.5 \mathrm{~mL}$ injections (NV1FGF: $0.2 \mathrm{mg} / \mathrm{mL}$ )

\begin{tabular}{ll}
\hline Outcomes & - Complete healing of at least one ulcer at weeks $13,25,38$ and 52 (at week 25 - primary) \\
- Major amputation/minor amputation (during the study period) \\
- Death (during the study period) \\
- Safety (during the study period) \\
- ISchaemic rest pain at each visit \\
\hline Notes \\
$\begin{array}{l}\text { aMITT population: included those who had received at least } 2 \text { treatment injections (8 } 8 \text { injections each) } \\
\text { of a study drug, undergone an evaluation for aggregate ulcer size at baseline and had at least } 1 \text { non- } \\
\text { healing ulcer as well as an evaluation for aggregate ulcer size at or after week } 5\end{array}$
\end{tabular}

\section{Risk of bias}

\begin{tabular}{lll}
\hline Bias & Authors' judgement & Support for judgement \\
\hline $\begin{array}{l}\text { Random sequence genera- } \\
\text { tion (selection bias) }\end{array}$ & Unclear risk & Procedure is not explicitly reported \\
\hline $\begin{array}{l}\text { Allocation concealment } \\
\text { (selection bias) }\end{array}$ & Unclear risk & Procedure is not explicitly reported \\
\hline $\begin{array}{l}\text { Blinding of participants } \\
\text { and personnel (perfor- } \\
\text { mance bias) } \\
\text { All outcomes }\end{array}$ & Unclear risk & Blinding procedure is not explicitly reported \\
\hline
\end{tabular}

Blinding of outcome as-
sessment (detection bias) $\quad$ Low risk Outcome measurement is not likely to be influenced by lack of blinding

Objective outcomes

\begin{tabular}{lll}
$\begin{array}{l}\text { Blinding of outcome as- } \\
\text { sessment (detection bias) } \\
\text { Subjective outcomes }\end{array}$ & Unclear risk & Blinding procedure is not explicitly reported \\
\hline $\begin{array}{l}\text { Incomplete outcome data } \\
\text { (attrition bias) }\end{array}$ & Low risk & Using data for all randomised participants \\
Death & &
\end{tabular}

\begin{tabular}{|c|c|c|}
\hline $\begin{array}{l}\text { Incomplete outcome data } \\
\text { (attrition bias) } \\
\text { Limb amputation }\end{array}$ & High risk & Data only for MITT population \\
\hline $\begin{array}{l}\text { Incomplete outcome data } \\
\text { (attrition bias) } \\
\text { Ulceration }\end{array}$ & High risk & Data only for MITT population \\
\hline $\begin{array}{l}\text { Incomplete outcome data } \\
\text { (attrition bias) } \\
\text { Rest pain }\end{array}$ & High risk & $\begin{array}{l}\text { Data only for MITT population; also no data for number of participants with } \\
\text { measurements }\end{array}$ \\
\hline
\end{tabular}


TALISMAN-201 (Continued)

Incomplete outcome data Unclear risk The study did not address this outcome
(attrition bias)

Walking ability

\begin{tabular}{lll}
\hline $\begin{array}{l}\text { Incomplete outcome data } \\
\text { (attrition bias) } \\
\text { Haemodynamic measures }\end{array}$ & High risk & $\begin{array}{l}\text { Data only for MITT population; also no data for number of participants with } \\
\text { measurements }\end{array}$ \\
\hline $\begin{array}{l}\text { Incomplete outcome data } \\
\text { (attrition bias) } \\
\begin{array}{l}\text { Adverse events /severe } \\
\text { complications }\end{array}\end{array}$ & Low risk & No missing data for safety population \\
\hline $\begin{array}{l}\text { Selective reporting (re- } \\
\text { porting bias) }\end{array}$ & Low risk & No reporting bias \\
\hline \begin{tabular}{l} 
Other bias \\
\hline
\end{tabular} & Low risk & The study appears to be free of other sources of bias \\
\hline
\end{tabular}

HGF-0205

\begin{tabular}{|c|c|}
\hline Methods & $\begin{array}{l}\text { Study design: stated as randomised, placebo-controlled, double-blind, phase II trial. } \\
\text { Multi-centre trial (8 centres); randomisation ratio: 4:1 or 3:1a } \\
\text { Recruitment: August } 2005 \text { - August } 2008 \text { (USA) }\end{array}$ \\
\hline Participants & $\begin{array}{l}\text { People with lower extremity ischaemic tissue loss (Rutherford } 5 \text { and } 6 \text { ) who were poor candidates for } \\
\text { standard revascularisation treatment options } \\
\text { ( } \mathrm{N} \text { randomised and received at least one dose }=27^{\mathrm{b}} \text {, EEc population }=21 \text { ) } \\
\text { Age (mean): } 78 \pm 2 \text { years (placebo), } 76 \pm 2 \text { years (HGF) } \\
\text { Sex ( } \mathrm{N} \text { males/females): } 2 / 4(33 \% / 67 \% \text {, placebo), } 13 / 8(62 \% / 38 \%, \mathrm{HGF})\end{array}$ \\
\hline & Severity: no data \\
\hline
\end{tabular}

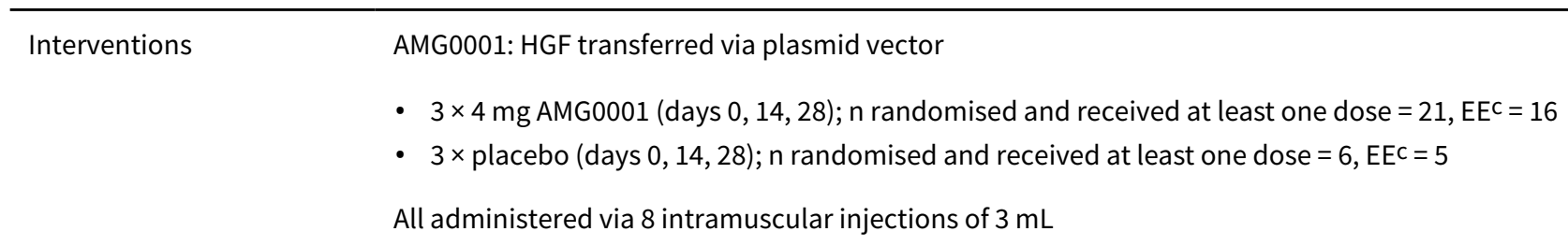

\begin{tabular}{ll}
\hline Outcomes & Wound healing at months 3,6 , and 12 (primary) \\
- Adverse events or serious adverse events at 12 months (primary safety outcome) \\
- Death at months 3,6 , and 12 \\
- Major amputation at months 3,6 , and 12 \\
- Pain at rest at months 3 and 6 \\
Notes & aDiscrepant data. \\
& bThe trial was stopped early (plan 48 randomised participants). \\
& cThe efficacy evaluable (EE) population included all participants who received all 3 doses and had at \\
least 1 follow-up visit after receiving all 3 doses but before having either a peripheral vascular interven- \\
tion or a major amputation.
\end{tabular}


HGF-0205 (Continued)

\section{Risk of bias}

\begin{tabular}{|c|c|c|}
\hline Bias & Authors' judgement & Support for judgement \\
\hline $\begin{array}{l}\text { Random sequence genera- } \\
\text { tion (selection bias) }\end{array}$ & Unclear risk & Procedure is not explicitly reported \\
\hline $\begin{array}{l}\text { Allocation concealment } \\
\text { (selection bias) }\end{array}$ & Unclear risk & Procedure is not explicitly reported \\
\hline $\begin{array}{l}\text { Blinding of participants } \\
\text { and personnel (perfor- } \\
\text { mance bias) } \\
\text { All outcomes }\end{array}$ & Unclear risk & Blinding procedure is not explicitly reported \\
\hline $\begin{array}{l}\text { Blinding of outcome as- } \\
\text { sessment (detection bias) } \\
\text { Objective outcomes }\end{array}$ & Low risk & Outcome measurement is not likely to be influenced by lack of blinding \\
\hline $\begin{array}{l}\text { Blinding of outcome as- } \\
\text { sessment (detection bias) } \\
\text { Subjective outcomes }\end{array}$ & Unclear risk & Blinding procedure is not explicitly reported \\
\hline $\begin{array}{l}\text { Incomplete outcome data } \\
\text { (attrition bias) } \\
\text { Death }\end{array}$ & Low risk & No missing data for safety population \\
\hline $\begin{array}{l}\text { Incomplete outcome data } \\
\text { (attrition bias) } \\
\text { Limb amputation }\end{array}$ & High risk & $\begin{array}{l}\text { Data in \% participants; differ between publications; some data probably for all } \\
\text { participants }\end{array}$ \\
\hline $\begin{array}{l}\text { Incomplete outcome data } \\
\text { (attrition bias) } \\
\text { Ulceration }\end{array}$ & High risk & Data based on efficacy evaluable population (6 of 27 participants excluded) \\
\hline $\begin{array}{l}\text { Incomplete outcome data } \\
\text { (attrition bias) } \\
\text { Rest pain }\end{array}$ & High risk & Data based on efficacy evaluable population (6 of 27 participants excluded) \\
\hline $\begin{array}{l}\text { Incomplete outcome data } \\
\text { (attrition bias) } \\
\text { Walking ability }\end{array}$ & Unclear risk & The study did not address this outcome \\
\hline $\begin{array}{l}\text { Incomplete outcome data } \\
\text { (attrition bias) } \\
\text { Haemodynamic measures }\end{array}$ & High risk & Data based on efficacy evaluable population (6 of 27 participants excluded) \\
\hline $\begin{array}{l}\text { Incomplete outcome data } \\
\text { (attrition bias) } \\
\text { Adverse events /severe } \\
\text { complications }\end{array}$ & Low risk & No missing data for safety population \\
\hline $\begin{array}{l}\text { Selective reporting (re- } \\
\text { porting bias) }\end{array}$ & Low risk & The study protocol is available; results for all relevant outcomes are provided \\
\hline Other bias & Low risk & The study appears to be free of other sources of bias \\
\hline
\end{tabular}




Methods Study design: stated as randomised, placebo-controlled, double-blind
Multicentre trial (30 centres), randomisation 2:1

Recruitment: February 2004 - June 2007 (Japan)

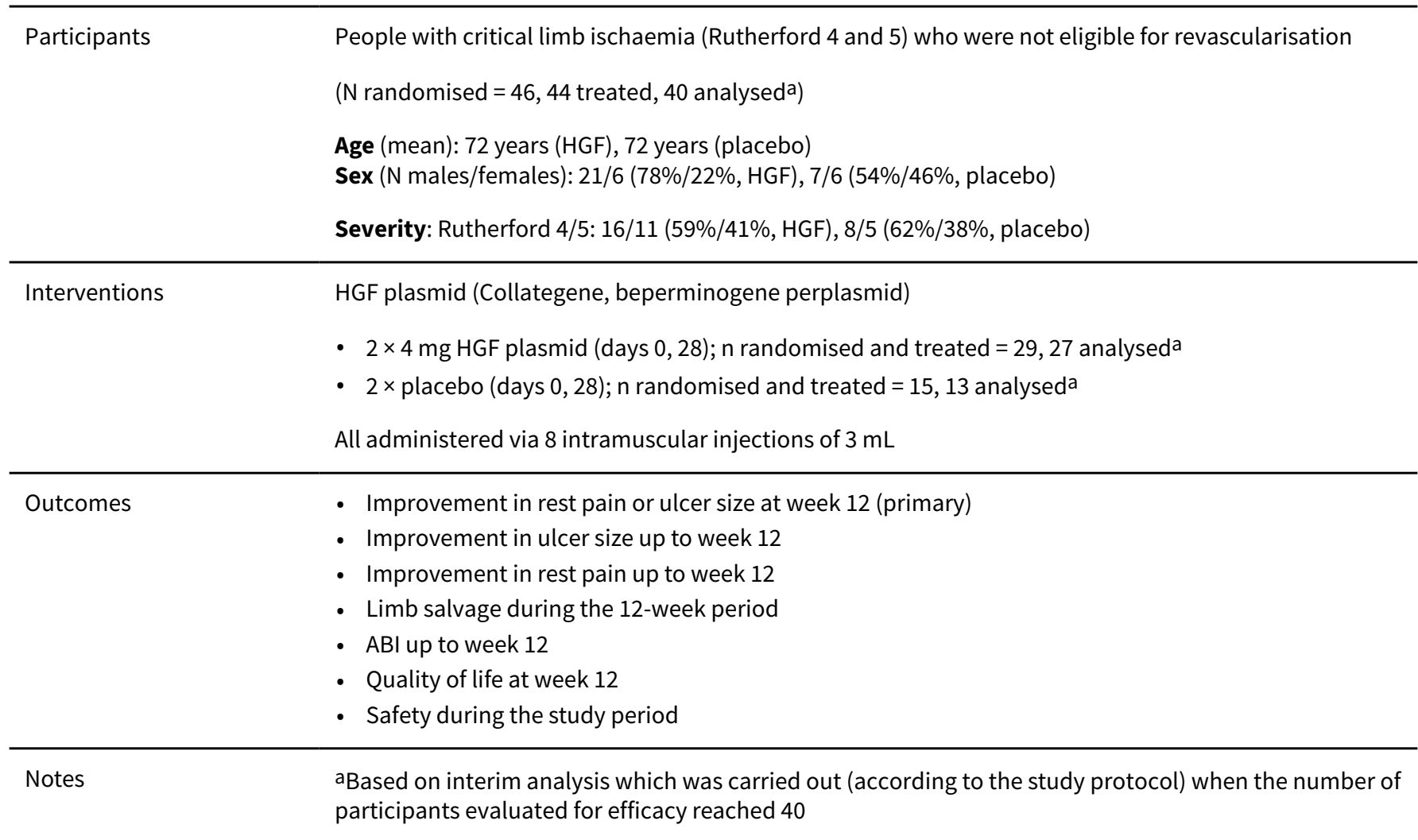

\section{Risk of bias}

\begin{tabular}{lll}
\hline Bias & Authors' judgement & Support for judgement \\
\hline $\begin{array}{l}\text { Random sequence genera- } \\
\text { tion (selection bias) }\end{array}$ & Low risk & Participants were randomly allocated by the central registration centre \\
\hline $\begin{array}{l}\text { Allocation concealment } \\
\text { (selection bias) }\end{array}$ & Low risk & Central randomisation \\
\hline $\begin{array}{l}\text { Blinding of participants } \\
\text { and personnel (perfor- } \\
\text { mance bias) } \\
\text { All outcomes }\end{array}$ & Low risk & The study medication was administered in a blinded manner \\
\hline $\begin{array}{l}\text { Blinding of outcome as- } \\
\text { sessment (detection bias) } \\
\text { Objective outcomes }\end{array}$ & Low risk & Outcome measurement is not likely to be influenced by lack of blinding \\
\hline $\begin{array}{l}\text { Blinding of outcome as- } \\
\text { sessment (detection bias) } \\
\text { Subjective outcomes }\end{array}$ & Unclear risk & Blinding procedure described only for administration of medication \\
\hline
\end{tabular}


Shigematsu 2010 (Continued)

Incomplete outcome data Low risk No missing data
(attrition bias)

Death

Incomplete outcome data Low risk No missing data
(attrition bias)
Limb amputation

\begin{tabular}{|c|c|c|}
\hline $\begin{array}{l}\text { Incomplete outcome data } \\
\text { (attrition bias) } \\
\text { Ulceration }\end{array}$ & High risk & Results only for subgroup of participants ( $40 \%)$ with ulcer at baseline \\
\hline $\begin{array}{l}\text { Incomplete outcome data } \\
\text { (attrition bias) } \\
\text { Rest pain }\end{array}$ & High risk & Results only for subgroup of participants (60\%) without ulcer at baseline \\
\hline $\begin{array}{l}\text { Incomplete outcome data } \\
\text { (attrition bias) } \\
\text { Walking ability }\end{array}$ & Unclear risk & Study did not address this outcome \\
\hline $\begin{array}{l}\text { Incomplete outcome data } \\
\text { (attrition bias) } \\
\text { Haemodynamic measures }\end{array}$ & Unclear risk & Data for up to $20 \%$ of all treated participants \\
\hline $\begin{array}{l}\text { Incomplete outcome data } \\
\text { (attrition bias) } \\
\text { Adverse events /severe } \\
\text { complications }\end{array}$ & Low risk & No missing data \\
\hline $\begin{array}{l}\text { Selective reporting (re- } \\
\text { porting bias) }\end{array}$ & Low risk & The study protocol is not available, but reporting bias is not expected \\
\hline Other bias & Low risk & The study appears to be free of other sources of bias \\
\hline
\end{tabular}

\section{TALISMAN-202}

\begin{tabular}{|c|c|}
\hline Methods & $\begin{array}{l}\text { Study design: stated as randomised, placebo-controlled, double-blind, phase II trial. } \\
\text { Multicentre trial (US hospitals) } \\
\text { Recruitment: June } 2002 \text { - July } 2005 \text { (USA) }\end{array}$ \\
\hline Participants & $\begin{array}{l}\text { People with critical limb ischaemia and with unhealing ulcer who were poor or not candidates for } \\
\text { revascularisation ( } \mathrm{N} \text { randomised }=71 \text { ) } \\
\text { Age: } 45 \text { years and older } \\
\text { Sex ( } \mathrm{N} \text { males/females): no data } \\
\text { Severity: no data }\end{array}$ \\
\hline Interventions & $\begin{array}{l}\text { NV1FGF: non-viral } 1 \text { fibroblast growth factor } \\
\text { - } 4 \text { sessions (every } 2 \text { weeks) of } 8 \text { IM injections NV1FGF: } 1 \text { of } 5 \text { treatment regimens; } 2 \text { to } 16 \mathrm{mg} \text {; ran- } \\
\text { domised not reported } \\
\text { - } 4 \text { sessions (every } 2 \text { weeks) of } 8 \text { IM injections placebo; } n \text { randomised not reported }\end{array}$ \\
\hline Outcomes & $\begin{array}{l}\text { - Efficacy: change in } \mathrm{tc} \mathrm{O}_{2} \text { (primary), } \mathrm{ABI}, \mathrm{TBI} \text {, ulcer healing, amputation, death } \\
\text { - Safety }\end{array}$ \\
\hline
\end{tabular}


TALISMAN-202 (Continued)

Notes Study completed 2005, but results not published (no reply to our enquiry)

\section{Risk of bias}

\begin{tabular}{lll}
\hline Bias & Authors' judgement & Support for judgement \\
\hline $\begin{array}{l}\text { Random sequence genera- } \\
\text { tion (selection bias) }\end{array}$ & Unclear risk & Procedure is not explicitly reported \\
\hline $\begin{array}{l}\text { Allocation concealment } \\
\text { (selection bias) }\end{array}$ & Unclear risk & Procedure is not explicitly reported \\
\hline $\begin{array}{l}\text { Blinding of participants } \\
\text { and personnel (perfor- } \\
\text { mance bias) }\end{array}$ & Unclear risk & Blinding procedure is not explicitly reported \\
All outcomes & \\
\hline
\end{tabular}

Blinding of outcome as-
sessment (detection bias) $\quad$ Oow risk $\quad$ Outcome measurement is not likely to be influenced by lack of blinding

Objective outcomes

\begin{tabular}{|c|c|c|}
\hline $\begin{array}{l}\text { Blinding of outcome as- } \\
\text { sessment (detection bias) } \\
\text { Subjective outcomes }\end{array}$ & Unclear risk & Blinding procedure is not explicitly reported \\
\hline
\end{tabular}

Incomplete outcome data Unclear risk $\quad$ Results not presented
(attrition bias)
Death

\begin{tabular}{l}
\hline Incomplete outcome data $\quad$ Unclear risk \\
(attrition bias) \\
Limb amputation
\end{tabular}

\begin{tabular}{lll}
\hline $\begin{array}{l}\text { Incomplete outcome data } \\
\text { (attrition bias) }\end{array}$ & Unclear risk & Results not presented \\
Ulceration & \\
\hline $\begin{array}{l}\text { Incomplete outcome data } \\
\text { (attrition bias) }\end{array}$ & Unclear risk & Results not presented \\
Rest pain & \\
\hline $\begin{array}{l}\text { Incomplete outcome data } \\
\text { (attrition bias) }\end{array}$ & Unclear risk & Results not presented \\
Walking ability & \\
\hline
\end{tabular}

\begin{tabular}{lll}
\hline $\begin{array}{l}\text { Incomplete outcome data } \\
\text { (attrition bias) }\end{array}$ & Unclear risk & \\
Haemodynamic measures & \\
\hline $\begin{array}{l}\text { Incomplete outcome data } \\
\text { (attrition bias) }\end{array}$ & Unclear risk & Results not presented \\
$\begin{array}{l}\text { Adverse events /severe } \\
\text { complications }\end{array}$ & \\
\hline
\end{tabular}

\begin{tabular}{lll}
\hline $\begin{array}{l}\text { Selective reporting (re- } \\
\text { porting bias) }\end{array}$ & High risk & Study completed, but results not published \\
\hline Other bias & Unclear risk & Insufficient information to assess whether an important risk of bias exists \\
\hline $\begin{array}{l}\text { Growth factors for angiogenesis in peripheral arterial disease (Review) } \\
\text { Copyright } \odot 2017 \text { The Cochrane Collaboration. Published by John Wiley \& Sons, Ltd. }\end{array}$
\end{tabular}


Recruitment: completion April 2008 (3 centres in the USA)

\begin{tabular}{|c|c|c|}
\hline Participants & \multicolumn{2}{|c|}{$\begin{array}{l}\text { People with moderate to high-risk critical limb ischaemia (no data for } N \text { enrolled) } \\
\text { Age: over } 21 \text { years } \\
\text { Sex (N males/females): no data } \\
\text { Severity: no data }\end{array}$} \\
\hline Interventions & \multicolumn{2}{|c|}{$\begin{array}{l}\text { VEGF: vascular endothelial growth factor } \\
\text { - pVGI.1 (VEGF-2); } n \text { randomised not reported } \\
\text { - Placebo. } n \text { randomised not reported } \\
\text { Delivery: IM injections on } 3 \text { separate occasions (interval } 2 \text { weeks) }\end{array}$} \\
\hline Outcomes & \multicolumn{2}{|c|}{$\begin{array}{l}\text { - Safety } \\
\text { - Efficacy (rest pain, ulcer healing) }\end{array}$} \\
\hline Notes & \multicolumn{2}{|c|}{ Study completed in 2008 , but results not published (no reply to our enquiry) } \\
\hline \multicolumn{3}{|l|}{ Risk of bias } \\
\hline Bias & Authors' judgement & Support for judgement \\
\hline $\begin{array}{l}\text { Random sequence genera- } \\
\text { tion (selection bias) }\end{array}$ & Unclear risk & Procedure not described \\
\hline $\begin{array}{l}\text { Allocation concealment } \\
\text { (selection bias) }\end{array}$ & Unclear risk & Procedure not described \\
\hline $\begin{array}{l}\text { Blinding of participants } \\
\text { and personnel (perfor- } \\
\text { mance bias) } \\
\text { All outcomes }\end{array}$ & Unclear risk & Blinding procedure not explicitly described \\
\hline
\end{tabular}

\begin{tabular}{lll}
\hline $\begin{array}{l}\text { Blinding of outcome as- } \\
\text { sessment (detection bias) } \\
\text { Objective outcomes }\end{array}$ & Low risk & Outcome measurement is not likely to be influenced by lack of blinding \\
\hline $\begin{array}{l}\text { Blinding of outcome as- } \\
\text { sessment (detection bias) } \\
\text { Subjective outcomes }\end{array}$ & Unclear risk & Blinding procedure not explicitly described \\
\hline $\begin{array}{l}\text { Incomplete outcome data } \\
\text { (attrition bias) }\end{array}$ & Unclear risk & Results not presented \\
$\begin{array}{l}\text { Death } \\
\text { Incomplete outcome data } \\
\text { (attrition bias) } \\
\text { Limb amputation }\end{array}$ & Unclear risk & Results not presented \\
\hline
\end{tabular}

$\begin{aligned} & \text { Incomplete outcome data } \\ & \text { (attrition bias) }\end{aligned}$
Unclear risk Results not presented


NCT00304837 (Continued)

Ulceration

\begin{tabular}{lll}
\hline $\begin{array}{l}\text { Incomplete outcome data } \\
\text { (attrition bias) } \\
\text { Rest pain }\end{array}$ & Unclear risk & Results not presented \\
\hline $\begin{array}{l}\text { Incomplete outcome data } \\
\text { (attrition bias) } \\
\text { Walking ability }\end{array}$ & Unclear risk & Results not presented \\
\hline $\begin{array}{l}\text { Incomplete outcome data } \\
\text { (attrition bias) } \\
\text { Haemodynamic measures }\end{array}$ & Unclear risk & Results not presented \\
\hline $\begin{array}{l}\text { Incomplete outcome data } \\
\text { (attrition bias) } \\
\begin{array}{l}\text { Adverse events /severe } \\
\text { complications }\end{array}\end{array}$ & Unclear risk & Results not presented \\
\hline $\begin{array}{l}\text { Selective reporting (re- } \\
\text { porting bias) }\end{array}$ & High risk & \\
\hline \begin{tabular}{l} 
Other bias \\
\hline
\end{tabular} & Unclear risk & Insufficient information to assess whether an important risk of bias exists \\
\hline
\end{tabular}

\section{TALISMAN-211}

\section{Methods}

Study design: stated as randomised, placebo-controlled, double-blind, dose-finding trial, multicentre trial

Recruitment: June 2004 - August 2005 (USA, Europe)

\begin{tabular}{ll}
\hline Participants & People with intermittent claudication (N randomised = 36) \\
& $\begin{array}{l}\text { Age: } 40 \text { years and older } \\
\text { Sex (N males/females): no data } \\
\text { Severity: no data }\end{array}$ \\
\hline Interventions & NV1FGF: non-viral 1 fibroblast growth factor \\
& $\begin{array}{l}\text { - } 4 \text { sessions (every } 2 \text { weeks) of each } 4 \text { mg NV1FGF in IM injections; } n \text { randomised not reported } \\
\text { - } 4 \text { sessions (every } 2 \text { weeks) of each } 8 \text { mg NV1FGF in IM injections; } n \text { randomised not reported }\end{array}$ \\
\hline Outcomes & - Safety (every 2 weeks) of placebo solution in IM injections; n randomised not reported \\
\hline Notes & Efficacy (primary outcome: change in absolute claudication distance) \\
\hline Risk of bias & Study has been completed 2005, but results not published (no reply to our enquiry) \\
\hline Bias & Authors' judgement Support for judgement \\
\hline Random sequence genera- & Unclear risk Procedure is not explicitly reported \\
\hline tion (selection bias) &
\end{tabular}


TALISMAN-211 (Continued)

\begin{tabular}{|c|c|c|}
\hline $\begin{array}{l}\text { Allocation concealment } \\
\text { (selection bias) }\end{array}$ & Unclear risk & Procedure is not explicitly reported \\
\hline $\begin{array}{l}\text { Blinding of participants } \\
\text { and personnel (perfor- } \\
\text { mance bias) } \\
\text { All outcomes }\end{array}$ & Unclear risk & Blinding procedure is not explicitly reported \\
\hline $\begin{array}{l}\text { Blinding of outcome as- } \\
\text { sessment (detection bias) } \\
\text { Objective outcomes }\end{array}$ & Low risk & Outcome measurement is not likely to be influenced by lack of blinding \\
\hline $\begin{array}{l}\text { Blinding of outcome as- } \\
\text { sessment (detection bias) } \\
\text { Subjective outcomes }\end{array}$ & Unclear risk & Blinding procedure is not explicitly reported \\
\hline $\begin{array}{l}\text { Incomplete outcome data } \\
\text { (attrition bias) } \\
\text { Death }\end{array}$ & Unclear risk & Results not presented \\
\hline
\end{tabular}

\begin{tabular}{l}
\hline $\begin{array}{l}\text { Incomplete outcome data } \\
\text { (attrition bias) }\end{array}$ \\
Limb amputation
\end{tabular}

Incomplete outcome data Unclear risk
(attrition bias)
Ulceration

\begin{tabular}{lll}
\hline Incomplete outcome data Unclear risk & Results not presented \\
(attrition bias)
\end{tabular}

Rest pain

\begin{tabular}{|c|c|c|}
\hline $\begin{array}{l}\text { Incomplete outcome data } \\
\text { (attrition bias) } \\
\text { Walking ability }\end{array}$ & Unclear risk & Results not presented \\
\hline $\begin{array}{l}\text { Incomplete outcome data } \\
\text { (attrition bias) } \\
\text { Haemodynamic measures }\end{array}$ & Unclear risk & Results not presented \\
\hline $\begin{array}{l}\text { Incomplete outcome data } \\
\text { (attrition bias) } \\
\text { Adverse events /severe } \\
\text { complications }\end{array}$ & Unclear risk & Results not presented \\
\hline $\begin{array}{l}\text { Selective reporting (re- } \\
\text { porting bias) }\end{array}$ & High risk & Study completed, but results not published \\
\hline Other bias & Unclear risk & Insufficient information to assess whether an important risk of bias exists \\
\hline
\end{tabular}

\section{TAMARIS}

Methods

Study design: stated as randomised, placebo-controlled, double-blind, phase III trial.

Multicentre trial ( 171 hospitals in 30 countries), block randomisation

Recruitment: December 2007 - July 2009. Study completion: August 2012 (30 countries) 
TAMARIS (Continued)

Participants
tion
(N randomised $=525 ; 523$ received allocated intervention)
Age (mean (range)): 69 years ( $50-92$, placebo) vs 71 years $(50-95$, NV1FGF)
Sex (N males/females): $181 / 78$ (70\%/30\%, placebo) vs $184 / 82(69 \% / 31 \%$, NV1FGF)

Severity: Gangrene: 55 of 259 (21\%, placebo) vs 60 of 266 (23\%, NV1FGF)
NV1FGF: non-viral 1 fibroblast growth factor

- $4 \times 4$ mg NV1FGF ( $n$ randomised = 266, 266 received intervention, 228 received all doses)

- $4 \times$ placebo ( $n$ randomised $=259,257$ received intervention, 228 received all doses)

Sessions on days 1, 15, 29, and 43 of each 8 IM $2.5 \mathrm{~mL}$ injections (NV1FGF: $0.2 \mathrm{mg} / \mathrm{mL}$ )

- Major amputation or death at 1 year (primary)
- Major amputation of the treated leg at 1 year
- Death from any cause at 1 year
- Skin lesion status ${ }^{a}$
- Pain intensity at resta
- Functionality and general health assessmenta
- Overall quality of lifea
- ABI and TBI measures

Notes aResults for this outcome not reported

\section{Risk of bias}

\begin{tabular}{|c|c|c|}
\hline Bias & Authors' judgement & Support for judgement \\
\hline $\begin{array}{l}\text { Random sequence genera- } \\
\text { tion (selection bias) }\end{array}$ & Low risk & The randomisation code list was generated with an electronic technique \\
\hline $\begin{array}{l}\text { Allocation concealment } \\
\text { (selection bias) }\end{array}$ & Low risk & $\begin{array}{l}\text { Randomisation was managed centrally by a central interactive voice response } \\
\text { system }\end{array}$ \\
\hline $\begin{array}{l}\text { Blinding of participants } \\
\text { and personnel (perfor- } \\
\text { mance bias) } \\
\text { All outcomes }\end{array}$ & Low risk & $\begin{array}{l}\text { The investigator, participant and sponsor study teams were masked to treat- } \\
\text { ment }\end{array}$ \\
\hline $\begin{array}{l}\text { Blinding of outcome as- } \\
\text { sessment (detection bias) } \\
\text { Objective outcomes }\end{array}$ & Low risk & Outcome measurement is not likely to be influenced by lack of blinding \\
\hline $\begin{array}{l}\text { Blinding of outcome as- } \\
\text { sessment (detection bias) } \\
\text { Subjective outcomes }\end{array}$ & Low risk & $\begin{array}{l}\text { The investigator, participant and sponsor study teams were masked to treat- } \\
\text { ment }\end{array}$ \\
\hline $\begin{array}{l}\text { Incomplete outcome data } \\
\text { (attrition bias) } \\
\text { Death }\end{array}$ & Low risk & No patient was lost to follow-up \\
\hline $\begin{array}{l}\text { Incomplete outcome data } \\
\text { (attrition bias) }\end{array}$ & Low risk & No patient was lost to follow-up \\
\hline
\end{tabular}


TAMARIS (Continued)

Limb amputation

\begin{tabular}{|c|c|c|}
\hline $\begin{array}{l}\text { Incomplete outcome data } \\
\text { (attrition bias) } \\
\text { Ulceration }\end{array}$ & Unclear risk & Results not presented \\
\hline $\begin{array}{l}\text { Incomplete outcome data } \\
\text { (attrition bias) } \\
\text { Rest pain }\end{array}$ & Unclear risk & Results not presented \\
\hline $\begin{array}{l}\text { Incomplete outcome data } \\
\text { (attrition bias) } \\
\text { Walking ability }\end{array}$ & Unclear risk & The study did not address this outcome \\
\hline $\begin{array}{l}\text { Incomplete outcome data } \\
\text { (attrition bias) } \\
\text { Haemodynamic measures }\end{array}$ & Unclear risk & Results not presented \\
\hline $\begin{array}{l}\text { Incomplete outcome data } \\
\text { (attrition bias) } \\
\text { Adverse events /severe } \\
\text { complications }\end{array}$ & Low risk & No patient was lost to follow-up \\
\hline $\begin{array}{l}\text { Selective reporting (re- } \\
\text { porting bias) }\end{array}$ & Unclear risk & Results not reported for a number of measured secondary outcomes \\
\hline Other bias & Low risk & The study appears to be free of other sources of bias \\
\hline
\end{tabular}

\section{Kibbe 2016}

Methods Study design: stated as randomised, placebo-controlled, double-blind, phase II trial. Multicentre trial (13 locations in the USA, 2 in Korea); Assignment in 2:2:1 fashion

Recruitment: from July 2010 to July 2012 (USA, Korea)

Participants

People with critical limb ischaemia, Rutherford class 4-5 (N randomised $=52$ )

Age: $18-90$ years; mean age 64 years (placebo), 66 years (low-dose), 67 years (high-dose)

Sex ( $\mathrm{N}$ males/females): 6/5 (placebo), 14/7 (low-dose), 13/7 (high-dose)

Severity: Rutherford class 4/5 (N participants): 7/4 (placebo), 12/9 (low-dose), 13/7 (high-dose)

\begin{tabular}{|c|c|}
\hline Interventions & 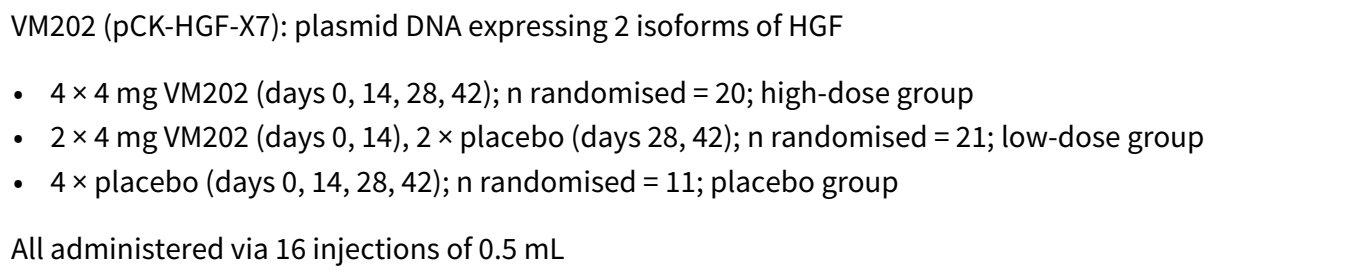 \\
\hline Outcomes & $\begin{array}{l}\text { - Safety over } 12 \text { months ( } \mathrm{n} \text { of all serious } \mathrm{AEs} / \mathrm{n} \text { clinically relevant serious AEs over } 12 \text { months; primary } \\
\text { outcome) } \\
\text { - Level of rest pain (VAS, mean } \pm \mathrm{SD} \text { ) through } 12 \text { months, } \mathrm{n}(\%) \text { participants with rest pain reduction at } \\
9 \text { months } \\
\text { - Haemodynamic parameters ( } \mathrm{ABI} \text {, mean } \pm \mathrm{SD} \text { ) through } 12 \text { months; mean change from baseline to } 9 \\
\text { months } \\
\text { - Wound healing through } 12 \text { months (complete ulcer healing; reduction in ulcer area }>50 \% \text {, new ul- } \\
\text { cers) }\end{array}$ \\
\hline
\end{tabular}


Kibbe 2016 (Continued)

- Quality of life (5 domains of VascuQol; mean \pm SD) through 12 months

- Amputations (major, minor) at 12 months

- Mortality through 12 months

- Rutherford classification at baseline and month 9

- $\mathrm{tcpO} \mathrm{O}_{2}$ (mean $\pm \mathrm{SD}$ ) through 12 months, $\mathrm{tc} p \mathrm{O}_{2}$ (median) at 12 months

Notes aAdditional data presented for ulcer healing on ulcer basis

\section{Risk of bias}

\begin{tabular}{lll}
\hline Bias & Authors' judgement & Support for judgement \\
\hline $\begin{array}{l}\text { Random sequence genera- } \\
\text { tion (selection bias) }\end{array}$ & Unclear risk & Procedure is not explicitly reported \\
\hline $\begin{array}{l}\text { Allocation concealment } \\
\text { (selection bias) }\end{array}$ & Unclear risk & Procedure is not explicitly reported \\
\hline $\begin{array}{l}\text { Blinding of participants } \\
\text { and personnel (perfor- } \\
\text { mance bias) }\end{array}$ & Unclear risk & Blinding procedure is not explicitly reported \\
All outcomes & \\
\hline
\end{tabular}

Blinding of outcome as-
$\begin{aligned} & \text { sessment (detection bias) } \\ & \text { Objective outcomes }\end{aligned}$

$\begin{array}{lll}\text { Blinding of outcome as- } & \text { Unclear risk } & \text { Blinding procedure is not explicitly reported } \\ \text { sessment (detection bias) } & \end{array}$

Subjective outcomes

\begin{tabular}{|c|c|c|}
\hline $\begin{array}{l}\text { Incomplete outcome data } \\
\text { (attrition bias) } \\
\text { Death }\end{array}$ & Low risk & Data for almost all participants \\
\hline $\begin{array}{l}\text { Incomplete outcome data } \\
\text { (attrition bias) } \\
\text { Limb amputation }\end{array}$ & Low risk & Data for almost all participants \\
\hline $\begin{array}{l}\text { Incomplete outcome data } \\
\text { (attrition bias) } \\
\text { Ulceration }\end{array}$ & High risk & Data for only approx. $50 \%$ of all participants \\
\hline
\end{tabular}

\begin{tabular}{lll}
\hline $\begin{array}{l}\text { Incomplete outcome data } \\
\text { (attrition bias) }\end{array}$ & Low risk & \\
Rest pain & \\
\hline $\begin{array}{l}\text { Incomplete outcome data } \\
\text { (attrition bias) }\end{array}$ & Unclear risk & The study did not address this outcome \\
Walking ability & \\
\hline $\begin{array}{l}\text { Incomplete outcome data } \\
\text { (attrition bias) } \\
\text { Haemodynamic measures }\end{array}$ & Unclear risk & No data for N participants with measurements \\
\hline
\end{tabular}


Kibbe 2016 (Continued)

\begin{tabular}{lll}
$\begin{array}{l}\text { Incomplete outcome data } \\
\text { (attrition bias) }\end{array}$ & Low risk \\
$\begin{array}{l}\text { Adverse events /severe } \\
\text { complications }\end{array}$ & \\
\hline $\begin{array}{l}\text { Selective reporting (re- } \\
\text { porting bias) }\end{array}$ & Low risk & All relevant results published \\
\hline Other bias & Low risk & The study appears to be free of other sources of bias \\
\hline
\end{tabular}

\section{NCT00080392}

Methods Study design: stated as randomised, placebo-controlled, double-blind, phase I trial, dose-escalation trial

Recruitment: March 2004 - December 2011 (3 centres in the USA)

\begin{tabular}{ll}
\hline Participants & People with intermittent claudication, N enrolment = 10 (plan) \\
Age: over 21 years \\
Sex (N males/females): no data \\
Severity: no data \\
\hline VEGF: vascular endothelial growth factor \\
- EW-A-401 (VEGF-A gene plasmid); $n$ randomised not reported \\
- Placebo; $n$ randomised not reported \\
Delivery by IM injection during a single session (10 injections)
\end{tabular}

\begin{tabular}{ll}
\hline Outcomes & Safety \\
- Toxicity \\
- Blood flow \\
- Walking capacity \\
- Quality of life
\end{tabular}

Notes The study was completed 2011, but results not published (no reply to our enquiry)

\section{Risk of bias}

\begin{tabular}{lll}
\hline Bias & Authors' judgement & Support for judgement \\
\hline $\begin{array}{l}\text { Random sequence genera- } \\
\text { tion (selection bias) }\end{array}$ & Unclear risk & Procedure not described \\
\hline $\begin{array}{l}\text { Allocation concealment } \\
\text { (selection bias) }\end{array}$ & Unclear risk & Procedure not described \\
\hline
\end{tabular}

Blinding of participants Unclear risk Blinding procedure not explicitly described
and personnel (perfor-
mance bias)
All outcomes

$\begin{aligned} & \text { Blinding of outcome as- } \\ & \text { sessment (detection bias) }\end{aligned} \quad$ Outcome measurement is not likely to be influenced by lack of blinding


NCT00080392 (Continued)

Objective outcomes

Blinding of outcome as-
sessment (detection bias) $\quad$ Unclear risk $\quad$ Blinding procedure not explicitly described

Subjective outcomes

\begin{tabular}{|c|c|c|}
\hline $\begin{array}{l}\text { Incomplete outcome data } \\
\text { (attrition bias) } \\
\text { Death }\end{array}$ & Unclear risk & Results not presented \\
\hline $\begin{array}{l}\text { Incomplete outcome data } \\
\text { (attrition bias) } \\
\text { Limb amputation }\end{array}$ & Unclear risk & Results not presented \\
\hline $\begin{array}{l}\text { Incomplete outcome data } \\
\text { (attrition bias) } \\
\text { Ulceration }\end{array}$ & Unclear risk & Results not presented \\
\hline $\begin{array}{l}\text { Incomplete outcome data } \\
\text { (attrition bias) } \\
\text { Rest pain }\end{array}$ & Unclear risk & Results not presented \\
\hline $\begin{array}{l}\text { Incomplete outcome data } \\
\text { (attrition bias) } \\
\text { Walking ability }\end{array}$ & Unclear risk & Results not presented \\
\hline $\begin{array}{l}\text { Incomplete outcome data } \\
\text { (attrition bias) } \\
\text { Haemodynamic measures }\end{array}$ & Unclear risk & Results not presented \\
\hline $\begin{array}{l}\text { Incomplete outcome data } \\
\text { (attrition bias) } \\
\text { Adverse events /severe } \\
\text { complications }\end{array}$ & Unclear risk & Results not presented \\
\hline $\begin{array}{l}\text { Selective reporting (re- } \\
\text { porting bias) }\end{array}$ & High risk & Study has been completed 2011, but results not published \\
\hline Other bias & Unclear risk & Insufficient information to assess whether an important risk of bias exists \\
\hline
\end{tabular}

Deev 2015

Methods Study design: stated as randomiseda, controlled, open-label, phase IIb/III trial.

Multicentre study (3 locations), randomisation 3:1

Recruitment: no data (Russian Federation)

\begin{tabular}{ll}
\hline Participants & $\begin{array}{l}\text { People with chronic lower limb ischaemia not suitable for revascularisation } \\
\text { (N randomised }=100 ; \text { all received allocated intervention) }\end{array}$
\end{tabular}

Age (mean): 71 years (control) vs 68 years (pCMV-vegf165)

Sex (N males/females): 20/5 (control) vs 60/15 (pCMV-vegf165)

Severity: ABI 0.46 (control) vs 0.51 (pCMV-vegf165) 
Deev 2015 (Continued)

- $2 \times 1.2$ mg pCMV-VEGF165 + standard pharmacological treatment; $\mathrm{n}=75$

- Standard pharmacological treatment alone; $n=25$

Administered intramuscularly at 4 to 5 injection sites, interval 14 days

\begin{tabular}{ll}
\hline Outcomes & Peak walking distance at 0.5 years, 1 year, 2 years (primarya) \\
& - ABI at 0.5 years, 1 year, 2 years \\
& - Quality of life at 0.5 years \\
\hline Notes & aDiscrepancy (adverse events, severe adverse events)
\end{tabular}

\section{Risk of bias}

\begin{tabular}{lll}
\hline Bias & Authors' judgement & Support for judgement \\
\hline $\begin{array}{l}\text { Random sequence genera- } \\
\text { tion (selection bias) }\end{array}$ & High risk & Discrepancy in text (randomised vs based on PWD value) \\
\hline $\begin{array}{l}\text { Allocation concealment } \\
\text { (selection bias) }\end{array}$ & Unclear risk & Procedure not described \\
\hline $\begin{array}{l}\text { Blinding of participants } \\
\text { and personnel (perfor- } \\
\text { mance bias) }\end{array}$ & High risk & Open-label trial \\
$\begin{array}{l}\text { All outcomes } \\
\text { Blinding of outcome as- } \\
\text { sessment (detection bias) } \\
\text { Objective outcomes }\end{array}$ & Low risk & Outcome measurement is not likely to be influenced by lack of blinding \\
\hline $\begin{array}{l}\text { Blinding of outcome as- } \\
\text { sessment (detection bias) } \\
\text { Subjective outcomes }\end{array}$ & High risk & \\
\hline $\begin{array}{l}\text { Incomplete outcome data } \\
\text { (attrition bias) } \\
\begin{array}{l}\text { Death } \\
\hline\end{array}\end{array}$ & Low risk & Open-label trial \\
\hline
\end{tabular}

\begin{tabular}{l}
\hline Incomplete outcome data Low risk Data probably for all participants \\
(attrition bias) \\
Limb amputation
\end{tabular}

\begin{tabular}{lll}
\hline $\begin{array}{l}\text { Incomplete outcome data } \\
\text { (attrition bias) } \\
\text { Ulceration }\end{array}$ & Unclear risk & The study did not address this outcome \\
\hline $\begin{array}{l}\text { Incomplete outcome data } \\
\text { (attrition bias) } \\
\text { Rest pain }\end{array}$ & Unclear risk & The study did not address this outcome \\
\hline $\begin{array}{l}\text { Incomplete outcome data } \\
\text { (attrition bias) }\end{array}$ & Unclear risk & N participants with missing data is not clear \\
$\begin{array}{l}\text { Walking ability } \\
\begin{array}{l}\text { Incomplete outcome data } \\
\text { (attrition bias) }\end{array}\end{array}$ & Unclear risk & N participants with missing data is not clear
\end{tabular}


Deev 2015 (Continued)

Haemodynamic measures

\begin{tabular}{lll}
\hline $\begin{array}{l}\text { Incomplete outcome data } \\
\text { (attrition bias) }\end{array}$ & Low risk \\
$\begin{array}{l}\text { Adverse events /severe } \\
\text { complications }\end{array}$ & \\
\hline $\begin{array}{l}\text { Selective reporting (re- } \\
\text { porting bias) }\end{array}$ & Low risk & The study protocol is not available, but reporting bias is not expected \\
\hline Other bias & Low risk & The study appears to be free of other sources of bias \\
\hline
\end{tabular}

\section{VM202-China}

Methods Study design: stated as randomised, placebo-controlled, double-blind, phase II trial, multicentre study (9 locations)

Recruitment: March 2012 - June 2014 (China)

Participants
\begin{tabular}{l} 
People with critical limb ischaemia, Rutherford class 4 or 5 (N randomised not reported, plan \\
Sex (N males/females): no data \\
Severity: no data \\
\hline NL003 (pCK-HGF-X7) - plasmid DNA: \\
- $3 \times 4$ mg NL003 + saline (days 0, 14, 28); $n$ randomised not reported; low-dose group \\
- $3 \times 6$ mg NL003 + saline (days 0, 14, 28); $n$ randomised not reported; middle-dose group \\
- $3 \times 8$ mg NL003 (days 0, 14, 28); $n$ randomised not reported; high-dose group \\
- $3 \times$ placebo (days 0, 14, 28); $n$ randomised not reported; placebo group \\
All administered via 32 IM injections of 0.5 mL NL003 or saline (placebo)
\end{tabular}

\begin{tabular}{ll}
\hline Outcomes & Safety \\
& - Efficacy (primary: ulcer area, level of rest pain)
\end{tabular}

Notes Study completed in 2014, but results not published (no reply to our enquiry)

\section{Risk of bias}

\begin{tabular}{|c|c|c|}
\hline Bias & Authors' judgement & Support for judgement \\
\hline $\begin{array}{l}\text { Random sequence genera- } \\
\text { tion (selection bias) }\end{array}$ & Unclear risk & Procedure is not explicitly reported \\
\hline $\begin{array}{l}\text { Allocation concealment } \\
\text { (selection bias) }\end{array}$ & Unclear risk & Procedure is not explicitly reported \\
\hline $\begin{array}{l}\text { Blinding of participants } \\
\text { and personnel (perfor- } \\
\text { mance bias) } \\
\text { All outcomes }\end{array}$ & Unclear risk & Blinding procedure is not explicitly reported \\
\hline $\begin{array}{l}\text { Blinding of outcome as- } \\
\text { sessment (detection bias) }\end{array}$ & Low risk & Outcome measurement is not likely to be influenced by lack of blinding \\
\hline
\end{tabular}


VM202-China (Continued)

Objective outcomes

\begin{tabular}{|c|c|c|}
\hline $\begin{array}{l}\text { Blinding of outcome as- } \\
\text { sessment (detection bias) } \\
\text { Subjective outcomes }\end{array}$ & Unclear risk & Blinding procedure is not explicitly reported \\
\hline $\begin{array}{l}\text { Incomplete outcome data } \\
\text { (attrition bias) } \\
\text { Death }\end{array}$ & Unclear risk & Results not presented \\
\hline $\begin{array}{l}\text { Incomplete outcome data } \\
\text { (attrition bias) } \\
\text { Limb amputation }\end{array}$ & Unclear risk & Results not presented \\
\hline $\begin{array}{l}\text { Incomplete outcome data } \\
\text { (attrition bias) } \\
\text { Ulceration }\end{array}$ & Unclear risk & Results not presented \\
\hline
\end{tabular}

\begin{tabular}{|c|c|c|}
\hline $\begin{array}{l}\text { Incomplete outcome data } \\
\text { (attrition bias) } \\
\text { Rest pain }\end{array}$ & Unclear risk & Results not presented \\
\hline $\begin{array}{l}\text { Incomplete outcome data } \\
\text { (attrition bias) } \\
\text { Walking ability }\end{array}$ & Unclear risk & Results not presented \\
\hline $\begin{array}{l}\text { Incomplete outcome data } \\
\text { (attrition bias) } \\
\text { Haemodynamic measures }\end{array}$ & Unclear risk & Results not presented \\
\hline $\begin{array}{l}\text { Incomplete outcome data } \\
\text { (attrition bias) } \\
\text { Adverse events /severe } \\
\text { complications }\end{array}$ & Unclear risk & Results not presented \\
\hline $\begin{array}{l}\text { Selective reporting (re- } \\
\text { porting bias) }\end{array}$ & High risk & Study completed, but results not published \\
\hline Other bias & Unclear risk & Insufficient information to assess whether an important risk of bias exists \\
\hline
\end{tabular}

ABI: ankle brachial index; AE: adverse event; CLI: critical limb ischaemia; FGF: fibroblast growth factor; HGF: hepatocyte growth factors; IM: intramuscular;MITT: modified intention to treat analysis;n/N: number in group or subgroup/total number in sample;PTA: percutaneous transluminal angioplasty; PWT: peak walking time;SD: standard deviation; SF: Short-Form; TBI: toe brachial index; tcp $\mathbf{O}_{\mathbf{2}}$ : transcutaneous oximetry; VEGF: vascular endothelial growth factor.

Characteristics of excluded studies [ordered by study ID]

\begin{tabular}{ll}
\hline Study & Reason for exclusion \\
\hline Afshari 2005 & No separate data for people with PAD \\
\hline Anghel 2011 & Not randomised \\
\hline Biggs 2009 & No relevant comparator: growth factor in all study arms \\
\hline C000000330 & Effect based not only on growth factor action \\
\hline
\end{tabular}




\begin{tabular}{|c|c|}
\hline Study & Reason for exclusion \\
\hline Capiod 2009 & Effect based not only on growth factor action \\
\hline Choi 2012 & Effect based not on growth factor action (GM-CSF release) \\
\hline Creager 2011 & Effect based not only on growth factor action \\
\hline Cui 2015 & No relevant comparator: growth factor in all study arms \\
\hline De Leeuw 2008 & Not RCT. Only data for some participants from another RCT \\
\hline Domanchuk 2013 & Effect based not on growth factor action (GM-CSF release) \\
\hline Doudar 2013 & Effect based not only on growth factor action \\
\hline Fernandez-Montequín 2009 & No separate data for people with PAD \\
\hline Gavrilenko 2008 & Not RCT; randomised only 32 of 38 participants. No separate data for randomised participants \\
\hline Grossman 2007 & Angiogenic factor, but effect based not on growth factor action \\
\hline Huang 2005 & Effect based not only on growth factor action \\
\hline Huang 2007 & Effect based not only on growth factor action \\
\hline JPRN-UMIN000002280 & Effect based not only on growth factor action \\
\hline Kalka 2000 & Not RCT or CCT \\
\hline Kirana 2012 & Effect based not only on growth factor action \\
\hline Lasala 2012 & Effect based not only on growth factor action \\
\hline Matoba 2008 & Effect based not only on growth factor action \\
\hline Mohammadzadeh 2013 & Effect based not only on growth factor action \\
\hline Mohler 2003 & Not RCT \\
\hline NCT01041417 & Effect based not on growth factor action (GM-CSF release) \\
\hline NCT01302015 & Effect based not only on growth factor action \\
\hline Niebuhr 2012 & Analysis of registry data (for some participants included in TALISMAN studies) \\
\hline Olson 2014 & HIF-1a effect based not only on growth factor action \\
\hline Ozturk 2012 & Effect based not only on growth factor action \\
\hline Perin 2011 & Effect based not only on growth factor action \\
\hline Poole 2013 & Effect based not on growth factor action (GM-CSF release) \\
\hline Prochazka 2010 & Effect based not only on growth factor action \\
\hline Rajagopalan 2002 & Not RCT \\
\hline
\end{tabular}




\begin{tabular}{ll}
\hline Study & Reason for exclusion \\
\hline Senet 2011 & No PAD disease \\
\hline Skora 2015 & Effect based not only on growth factor action \\
\hline Subramaniyam 2009 & Effect based not on growth factor action (GM-CSF release) \\
\hline Tateishi-Yuyama 2002 & Effect based not only on growth factor action \\
\hline Van Royen 2005 & Effect based not on growth factor action (GM-CSF release) \\
\hline Wang 2014 & No growth factor-action; panax notoginseng saponins (PNS) \\
\hline Wen 2010 & Effect based not only on growth factor action \\
\hline Yonemitsu 2013 & Not RCT or CCT \\
\hline Zafarghandi 2010 & Effect based not on growth factor action (GM-CSF release) \\
\hline
\end{tabular}

CCT: controlled clinical trial; GM-CSF: granulocyte macrophage colony-stimulating factor; PAD: peripheral arterial disease; RCT: randomised controlled trial.

\section{Characteristics of ongoing studies [ordered by study ID]}

AGILITY

\begin{tabular}{ll}
\hline Trial name or title & AGILITY ("Efficacy and safety of AMG0001 in subjects with critical limb ischemia (AGILITY)") \\
\hline Methods & Phase 3 double-blind, randomised, placebo-controlled study \\
\hline Participants & Participants with critical limb ischaemia (N = 500, plan) \\
\hline Interventions & HGF plasmid (AMG0001) vs placebo \\
\hline Outcomes & Safety/efficacy study \\
\hline Starting date & October 2014 \\
\hline Contact information & Colleen M Davenport, PhD 240-422-0792 cdavenport@anges-inc.com \\
& Principal investigator: Richard J Powell, MD Dartmouth-Hitchcock Medical Center \\
\hline Notes & This study is currently recruiting participants \\
& Estimated study completion date: February 2019 \\
\hline
\end{tabular}

NCT00424866

\begin{tabular}{ll}
\hline Trial name or title & NCT00424866 ("FGF-1 for intramuscular injection for the treatment of peripheral arterial disease") \\
\hline Methods & Randomised, phase 1, open label, dose response, pilot study \\
\hline Participants & People with peripheral arterial disease and intermittent claudication ( $N=24$, plan) \\
\hline
\end{tabular}


NCT00424866 (Continued)

\begin{tabular}{ll} 
Interventions & FGF-1: low dose $(3.0 \mu \mathrm{g} / \mathrm{kg})$, medium dose $(10 \mu \mathrm{g} / \mathrm{kg})$, high dose $(30 \mu \mathrm{g} / \mathrm{kg}) \mathrm{vs} \mathrm{placebo}$ \\
\hline Outcomes & Safety and tolerability \\
\hline Starting date & December 2014 \\
\hline Contact information & CardioVasc BioTherapeutics Inc. \\
\hline Notes & The study is not yet open for participant recruitment \\
& Estimated study completion date: December 2014 \\
& Data from CardioVasc BioTherapeutics Inc. inquired
\end{tabular}

\begin{tabular}{|c|c|}
\hline Trial name or title & NCT02276937 ("Randomized phase IIb trial of DVC1-0101") \\
\hline Participants & People with claudication intermittent ( $N=60$, plan) \\
\hline Interventions & $\begin{array}{l}\left.\text { Virus expressing FGF-2 gene (DVC1-0101): low dose ( } 1 \times 10^{\wedge} 9 \mathrm{ciu} / \mathrm{limb}\right) \text {, high dose }\left(5 \times 10^{9} \mathrm{ciu} / \mathrm{limb}\right) \\
\text { vs placebo }\end{array}$ \\
\hline Outcomes & Safety/efficacy study \\
\hline Starting date & October 2014 \\
\hline \multirow[t]{3}{*}{ Notes } & This study is currently recruiting participants \\
\hline & Estimated study completion date: October 2017 \\
\hline & Data from Prof Maehara inquired \\
\hline
\end{tabular}

FGF: fibroblast growth factor; HGF: hepatocyte growth factors.

\section{DATA AND ANALYSES}

\section{Comparison 1. Growth factors versus placebo (or no therapy)}

\begin{tabular}{lllll}
\hline $\begin{array}{l}\text { Outcome or subgroup } \\
\text { title }\end{array}$ & No. of studies & $\begin{array}{l}\text { No. of partici- } \\
\text { pants }\end{array}$ & Statistical method & Effect size \\
\hline $\begin{array}{l}1 \text { Limb amputation (ma- } \\
\text { jor or not specified; at } 1 \\
\text { year) }\end{array}$ & 6 & 916 & Odds Ratio (M-H, Fixed, 95\% Cl) & $1.00[0.71,1.41]$ \\
\hline 1.1 FGF & 2 & 632 & Odds Ratio (M-H, Fixed, 95\% Cl) & $1.01[0.70,1.46]$ \\
\hline
\end{tabular}




\begin{tabular}{|c|c|c|c|c|}
\hline $\begin{array}{l}\text { Outcome or subgroup } \\
\text { title }\end{array}$ & No. of studies & $\begin{array}{l}\text { No. of partici- } \\
\text { pants }\end{array}$ & Statistical method & Effect size \\
\hline $1.2 \mathrm{HGF}$ & 2 & 79 & Odds Ratio (M-H, Fixed, 95\% Cl) & $1.14[0.27,4.81]$ \\
\hline 1.3 VEGF & 2 & 205 & Odds Ratio (M-H, Fixed, 95\% Cl) & $0.70[0.17,2.96]$ \\
\hline $\begin{array}{l}2 \text { Limb amputation (ma- } \\
\text { jor or not specified; last } \\
\text { data to } 2 \text { years) }\end{array}$ & 10 & 1075 & Odds Ratio (M-H, Fixed, 95\% Cl) & $0.99[0.71,1.38]$ \\
\hline 2.1 FGF & 3 & 643 & Odds Ratio (M-H, Fixed, 95\% Cl) & $1.05[0.73,1.50]$ \\
\hline 2.2 HGF & 3 & 119 & Odds Ratio (M-H, Fixed, 95\% Cl) & $1.14[0.27,4.81]$ \\
\hline 2.3 VEGF & 4 & 313 & Odds Ratio (M-H, Fixed, 95\% Cl) & $0.62[0.24,1.63]$ \\
\hline $\begin{array}{l}3 \text { Limb amputation (any } \\
\text { or not specified; at } 1 \\
\text { year) }\end{array}$ & 4 & 364 & Odds Ratio (M-H, Fixed, 95\% Cl) & $0.54[0.29,1.00]$ \\
\hline $3.1 \mathrm{FGF}$ & 1 & 107 & Odds Ratio (M-H, Fixed, 95\% Cl) & $0.48[0.22,1.04]$ \\
\hline $3.2 \mathrm{HGF}$ & 1 & 52 & Odds Ratio (M-H, Fixed, 95\% Cl) & $0.65[0.14,3.00]$ \\
\hline 3.3 VEGF & 2 & 205 & Odds Ratio (M-H, Fixed, 95\% Cl) & $0.70[0.17,2.96]$ \\
\hline $\begin{array}{l}4 \text { Limb amputation (any } \\
\text { or not specified; last data } \\
\text { to } 2 \text { years) }\end{array}$ & 6 & 415 & Odds Ratio (M-H, Fixed, 95\% Cl) & $0.56[0.31,0.99]$ \\
\hline 4.1 FGF & 2 & 118 & Odds Ratio (M-H, Fixed, 95\% Cl) & $0.60[0.29,1.24]$ \\
\hline 4.2 HGF & 2 & 92 & Odds Ratio (M-H, Fixed, 95\% Cl) & $0.48[0.13,1.81]$ \\
\hline 4.3 VEGF & 2 & 205 & Odds Ratio (M-H, Fixed, 95\% Cl) & $0.51[0.13,1.91]$ \\
\hline $\begin{array}{l}5 \text { Death (of any cause; at } \\
1 \text { year) }\end{array}$ & 7 & 1038 & Odds Ratio (M-H, Fixed, 95\% Cl) & $0.98[0.67,1.44]$ \\
\hline $5.1 \mathrm{FGF}$ & 2 & 650 & Odds Ratio (M-H, Fixed, 95\% Cl) & $1.03[0.68,1.55]$ \\
\hline $5.2 \mathrm{HGF}$ & 3 & 183 & Odds Ratio (M-H, Fixed, 95\% Cl) & $0.74[0.22,2.54]$ \\
\hline 5.3 VEGF & 2 & 205 & Odds Ratio (M-H, Fixed, 95\% Cl) & $0.79[0.17,3.73]$ \\
\hline $\begin{array}{l}6 \text { Death (from any cause; } \\
\text { last data to } 2 \text { years) }\end{array}$ & 12 & 1371 & Odds Ratio (M-H, Fixed, 95\% Cl) & $0.99[0.69,1.41]$ \\
\hline $6.1 \mathrm{FGF}$ & 5 & 875 & Odds Ratio (M-H, Fixed, 95\% Cl) & $1.03[0.69,1.53]$ \\
\hline $6.2 \mathrm{HGF}$ & 3 & 183 & Odds Ratio (M-H, Fixed, 95\% Cl) & $0.74[0.22,2.54]$ \\
\hline 6.3 VEGF & 4 & 313 & Odds Ratio (M-H, Fixed, 95\% Cl) & $0.91[0.30,2.74]$ \\
\hline $\begin{array}{l}7 \text { Adverse events (seri- } \\
\text { ous; only aggregate data, } \\
\text { up to } 2 \text { years) }\end{array}$ & 6 & 865 & Odds Ratio (M-H, Fixed, 95\% Cl) & $1.11[0.74,1.65]$ \\
\hline
\end{tabular}




\begin{tabular}{|c|c|c|c|c|}
\hline $\begin{array}{l}\text { Outcome or subgroup } \\
\text { title }\end{array}$ & No. of studies & $\begin{array}{l}\text { No. of partici- } \\
\text { pants }\end{array}$ & Statistical method & Effect size \\
\hline $7.1 \mathrm{FGF}$ & 2 & 641 & Odds Ratio (M-H, Fixed, 95\% Cl) & $1.08[0.65,1.81]$ \\
\hline $7.2 \mathrm{HGF}$ & 4 & 224 & Odds Ratio (M-H, Fixed, 95\% Cl) & $1.15[0.61,2.16]$ \\
\hline 7.3 VEGF & 0 & 0 & Odds Ratio (M-H, Fixed, 95\% Cl) & $0.0[0.0,0.0]$ \\
\hline $\begin{array}{l}8 \text { Adverse events (seri- } \\
\text { ous; incl. data for single } \\
\text { events, up to } 2 \text { years) }\end{array}$ & 13 & 1411 & Odds Ratio (M-H, Fixed, 95\% Cl) & $1.09[0.79,1.50]$ \\
\hline 8.1 FGF & 5 & 874 & Odds Ratio (M-H, Fixed, 95\% Cl) & $1.20[0.76,1.90]$ \\
\hline 8.2 HGF & 4 & 224 & Odds Ratio (M-H, Fixed, 95\% Cl) & $1.15[0.61,2.16]$ \\
\hline 8.3 VEGF & 4 & 313 & Odds Ratio (M-H, Fixed, 95\% Cl) & $0.84[0.43,1.62]$ \\
\hline $\begin{array}{l}9 \text { Adverse events (any; } \\
\text { only aggregated data, up } \\
\text { to } 2 \text { years) }\end{array}$ & 4 & 709 & Odds Ratio (M-H, Fixed, 95\% Cl) & $1.10[0.73,1.64]$ \\
\hline 9.1 FGF & 2 & 641 & Odds Ratio (M-H, Fixed, 95\% Cl) & $1.06[0.70,1.59]$ \\
\hline $9.2 \mathrm{HGF}$ & 2 & 68 & Odds Ratio (M-H, Fixed, 95\% Cl) & $2.93[0.38,22.70]$ \\
\hline 9.3 VEGF & 0 & 0 & Odds Ratio (M-H, Fixed, 95\% Cl) & $0.0[0.0,0.0]$ \\
\hline $\begin{array}{l}10 \text { Adverse events (any; } \\
\text { incl. data for single } \\
\text { events, up to } 2 \text { years) }\end{array}$ & 13 & 1411 & Odds Ratio (M-H, Fixed, 95\% Cl) & $1.52[1.15,2.02]$ \\
\hline 10.1 FGF & 5 & 874 & Odds Ratio (M-H, Fixed, 95\% Cl) & $1.45[1.02,2.06]$ \\
\hline $10.2 \mathrm{HGF}$ & 4 & 224 & Odds Ratio (M-H, Fixed, 95\% Cl) & $2.77[1.24,6.22]$ \\
\hline 10.3 VEGF & 4 & 313 & Odds Ratio (M-H, Fixed, 95\% Cl) & $1.34[0.75,2.38]$ \\
\hline $\begin{array}{l}11 \text { Walking ability } \\
\text { (change in peak walking } \\
\text { time [min]; last data to } 6 \\
\text { months) }\end{array}$ & 3 & 279 & Mean Difference (IV, Fixed, 95\% Cl) & $-0.17[-0.69,0.36]$ \\
\hline 11.1 FGF & 2 & 192 & Mean Difference (IV, Fixed, 95\% Cl) & $-0.13[-0.67,0.41]$ \\
\hline $11.2 \mathrm{HGF}$ & 0 & 0 & Mean Difference (IV, Fixed, 95\% Cl) & $0.0[0.0,0.0]$ \\
\hline 11.3 VEGF & 1 & 87 & Mean Difference (IV, Fixed, 95\% Cl) & $-0.70[-2.78,1.38]$ \\
\hline $\begin{array}{l}12 \text { Walking ability } \\
\text { (change in claudication } \\
\text { onset time [min]; last da- } \\
\text { ta to } 6 \text { months) }\end{array}$ & 3 & 279 & Mean Difference (IV, Fixed, 95\% Cl) & $-0.07[-0.31,0.17]$ \\
\hline 12.1 FGF & 2 & 192 & Mean Difference (IV, Fixed, 95\% Cl) & $-0.05[-0.29,0.19]$ \\
\hline 12.2 HGF & 0 & 0 & Mean Difference (IV, Fixed, 95\% CI) & $0.0[0.0,0.0]$ \\
\hline
\end{tabular}




\begin{tabular}{|c|c|c|c|c|}
\hline $\begin{array}{l}\text { Outcome or subgroup } \\
\text { title }\end{array}$ & No. of studies & $\begin{array}{l}\text { No. of partici- } \\
\text { pants }\end{array}$ & Statistical method & Effect size \\
\hline 12.3 VEGF & 1 & 87 & Mean Difference (IV, Fixed, 95\% CI) & $-1.6[-3.61,0.41]$ \\
\hline $\begin{array}{l}13 \text { Haemodynamic mea- } \\
\text { sures (change in } A B I \text {; last } \\
\text { data to } 6 \text { months) }\end{array}$ & 6 & 341 & Mean Difference (IV, Fixed, 95\% CI) & $0.04[-0.02,0.10]$ \\
\hline 13.1 FGF & 2 & 116 & Mean Difference (IV, Fixed, 95\% CI) & $0.04[-0.07,0.15]$ \\
\hline 13.2 HGF & 2 & 73 & Mean Difference (IV, Fixed, 95\% CI) & $-0.03[-0.16,0.10]$ \\
\hline 13.3 VEGF & 2 & 152 & Mean Difference (IV, Fixed, 95\% CI) & $0.07[-0.02,0.15]$ \\
\hline $\begin{array}{l}14 \text { Haemodynamic mea- } \\
\text { sures (change in TBI; last } \\
\text { data to } 6 \text { months) }\end{array}$ & 2 & 128 & Mean Difference (IV, Fixed, 95\% CI) & $0.04[-0.01,0.09]$ \\
\hline 14.1 FGF & 1 & 107 & Mean Difference (IV, Fixed, 95\% CI) & $0.01[-0.04,0.06]$ \\
\hline 14.2 HGF & 1 & 21 & Mean Difference (IV, Fixed, 95\% CI) & $0.22[0.09,0.35]$ \\
\hline 14.3 VEGF & 0 & 0 & Mean Difference (IV, Fixed, 95\% CI) & $0.0[0.0,0.0]$ \\
\hline $\begin{array}{l}15 \text { Ulceration (complete } \\
\text { ulcer healing; last data to } \\
1 \text { year) }\end{array}$ & 6 & 189 & Odds Ratio (M-H, Fixed, 95\% Cl) & $1.88[0.89,3.97]$ \\
\hline 15.1 FGF & 2 & 113 & Odds Ratio (M-H, Fixed, 95\% Cl) & $1.42[0.53,3.81]$ \\
\hline 15.2 HGF & 3 & 62 & Odds Ratio (M-H, Fixed, 95\% Cl) & $4.54[1.02,20.21]$ \\
\hline 15.3 VEGF & 1 & 14 & Odds Ratio (M-H, Fixed, 95\% Cl) & $0.67[0.06,6.87]$ \\
\hline $\begin{array}{l}16 \text { Ulceration (improve- } \\
\text { ment in ulcer size; last } \\
\text { data to } 1 \text { year) }\end{array}$ & 3 & 79 & Odds Ratio (M-H, Fixed, 95\% Cl) & $17.57[3.37,91.65]$ \\
\hline 16.1 FGF & 0 & 0 & Odds Ratio (M-H, Fixed, 95\% Cl) & $0.0[0.0,0.0]$ \\
\hline 16.2 HGF & 2 & 41 & Odds Ratio (M-H, Fixed, 95\% Cl) & $17.21[2.52,117.38]$ \\
\hline 16.3 VEGF & 1 & 38 & Odds Ratio (M-H, Fixed, 95\% Cl) & $18.10[0.95,344.54]$ \\
\hline $\begin{array}{l}17 \text { Rest pain (change on } \\
10 \mathrm{~cm} \text { VAS; last data to } 1 \\
\text { year) }\end{array}$ & 4 & 191 & Mean Difference (IV, Fixed, 95\% CI) & $-1.09[-1.83,-0.35]$ \\
\hline 17.1 FGF & 2 & 118 & Mean Difference (IV, Fixed, 95\% CI) & $-1.07[-1.91,-0.24]$ \\
\hline $17.2 \mathrm{HGF}$ & 2 & 73 & Mean Difference (IV, Fixed, 95\% CI) & $-1.16[-2.76,0.43]$ \\
\hline 17.3 VEGF & 0 & 0 & Mean Difference (IV, Fixed, 95\% CI) & $0.0[0.0,0.0]$ \\
\hline $\begin{array}{l}18 \text { Rest pain (improve- } \\
\text { ment; last data to } 1 \text { year) }\end{array}$ & 5 & 133 & Odds Ratio (M-H, Fixed, 95\% Cl) & $1.89[0.80,4.42]$ \\
\hline
\end{tabular}




\begin{tabular}{lllll}
\hline $\begin{array}{l}\text { Outcome or subgroup } \\
\text { title }\end{array}$ & No. of studies & $\begin{array}{l}\text { No. of partici- } \\
\text { pants }\end{array}$ & Statistical method & Effect size \\
\hline $18.1 \mathrm{FGF}$ & 11 & Odds Ratio (M-H, Fixed, 95\% Cl) & $1.2[0.07,19.63]$ \\
\hline $18.2 \mathrm{HGF}$ & 1 & 76 & Odds Ratio (M-H, Fixed, 95\% Cl) & $2.83[0.93,8.59]$ \\
\hline 18.3 VEGF & 2 & 46 & Odds Ratio (M-H, Fixed, 95\% Cl) & $0.99[0.21,4.57]$ \\
\hline
\end{tabular}

Analysis 1.1. Comparison 1 Growth factors versus placebo (or no therapy), Outcome 1 Limb amputation (major or not specified; at 1 year).

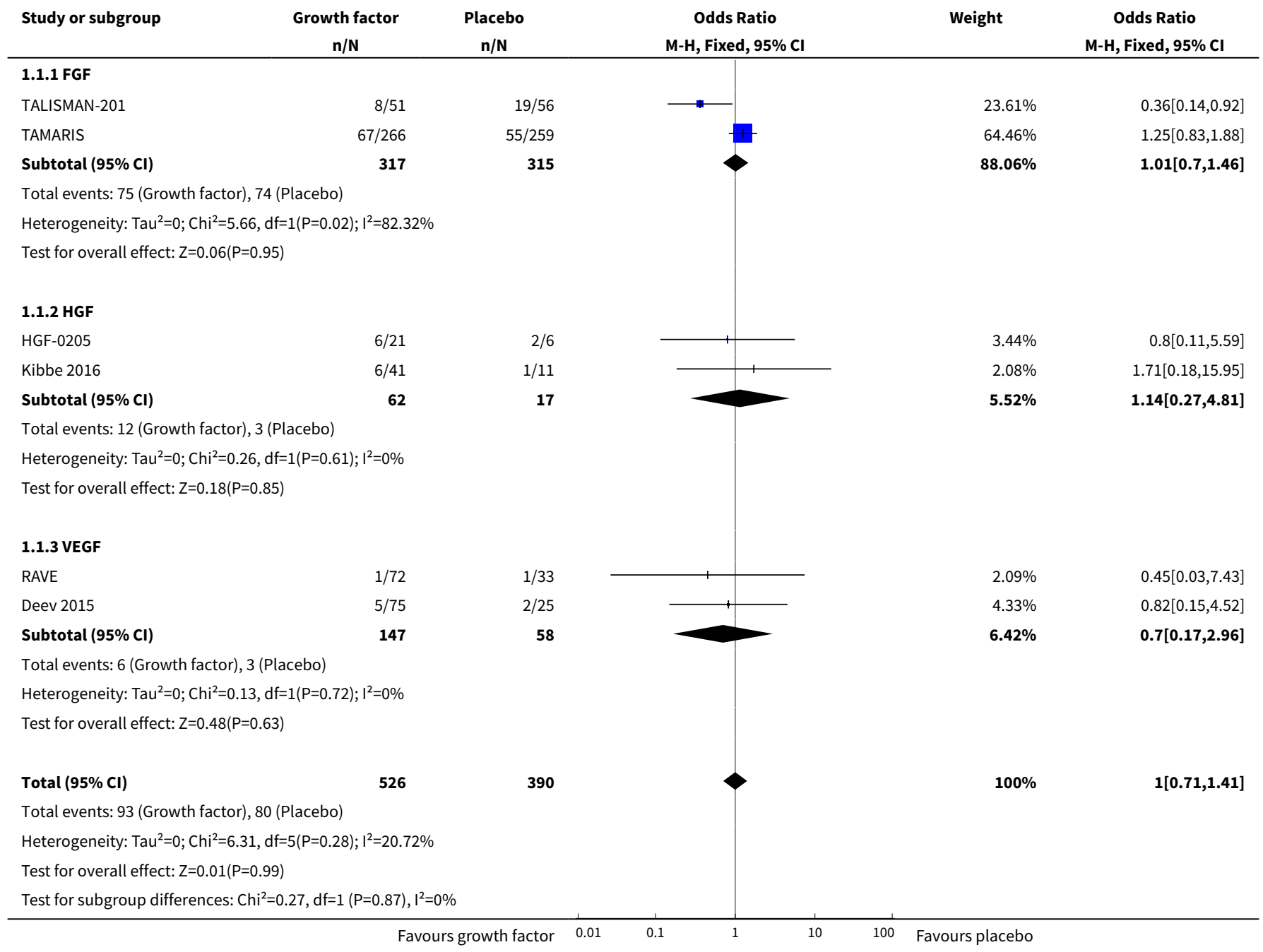


Analysis 1.2. Comparison 1 Growth factors versus placebo (or no therapy), Outcome 2 Limb amputation (major or not specified; last data to 2 years).

\begin{tabular}{|c|c|c|c|c|c|}
\hline Study or subgroup & $\begin{array}{c}\text { Growth factor } \\
n / N \\
\end{array}$ & $\begin{array}{c}\text { Placebo } \\
\mathbf{n} / \mathbf{N}\end{array}$ & $\begin{array}{c}\text { Odds Ratio } \\
\text { M-H, Fixed, } 95 \% \mathrm{Cl}\end{array}$ & Weight & $\begin{array}{c}\text { Odds Ratio } \\
\text { M-H, Fixed, } 95 \% \mathrm{Cl}\end{array}$ \\
\hline \multicolumn{6}{|l|}{ 1.2.1 FGF } \\
\hline Matyas 2005 & $4 / 8$ & $0 / 3$ & & $0.49 \%$ & $7[0.27,178.47]$ \\
\hline TALISMAN-201 & $8 / 51$ & $19 / 56$ & $\because$ & $21.51 \%$ & $0.36[0.14,0.92]$ \\
\hline TAMARIS & $67 / 266$ & $55 / 259$ & & $58.74 \%$ & $1.25[0.83,1.88]$ \\
\hline Subtotal $(95 \% \mathrm{Cl})$ & 325 & 318 & & $80.74 \%$ & $1.05[0.73,1.5]$ \\
\hline \multicolumn{6}{|c|}{ Total events: 79 (Growth factor), 74 (Placebo) } \\
\hline \multicolumn{6}{|c|}{ Heterogeneity: $\mathrm{Tau}^{2}=0 ; \mathrm{Chi}^{2}=6.99, \mathrm{df}=2(\mathrm{P}=0.03) ; \mathrm{I}^{2}=71.37 \%$} \\
\hline \multicolumn{6}{|c|}{ Test for overall effect: $Z=0.25(P=0.8)$} \\
\hline \multicolumn{6}{|l|}{ 1.2.2 HGF } \\
\hline HGF-0205 & $6 / 21$ & $2 / 6$ & & $3.13 \%$ & $0.8[0.11,5.59]$ \\
\hline Shigematsu 2010 & $0 / 27$ & $0 / 13$ & & & Not estimable \\
\hline Subtotal $(95 \% \mathrm{Cl})$ & 89 & 30 & & $5.03 \%$ & $1.14[0.27,4.81]$ \\
\hline \multicolumn{6}{|c|}{ Total events: 12 (Growth factor), 3 (Placebo) } \\
\hline \multicolumn{6}{|c|}{ Heterogeneity: $\operatorname{Tau}^{2}=0 ; \mathrm{Chi}^{2}=0.26, \mathrm{df}=1(\mathrm{P}=0.61) ;\left.\right|^{2}=0 \%$} \\
\hline \multicolumn{6}{|c|}{ Test for overall effect: $Z=0.18(P=0.85)$} \\
\hline \multicolumn{6}{|l|}{ 1.2.3 VEGF } \\
\hline Makinen 2002 & $1 / 35$ & $0 / 19$ & & $0.87 \%$ & $1.7[0.07,43.66]$ \\
\hline RAVE & $1 / 72$ & $1 / 33$ & & $1.91 \%$ & $0.45[0.03,7.43]$ \\
\hline Kusumanto 2006 & $3 / 27$ & $6 / 27$ & $\longrightarrow$ & $7.51 \%$ & $0.44[0.1,1.97]$ \\
\hline Deev 2015 & $5 / 75$ & $2 / 25$ & & $3.94 \%$ & $0.82[0.15,4.52]$ \\
\hline Subtotal $(95 \% \mathrm{Cl})$ & 209 & 104 & & $14.23 \%$ & $0.62[0.24,1.63]$ \\
\hline \multicolumn{6}{|c|}{ Total events: 10 (Growth factor), 9 (Placebo) } \\
\hline \multicolumn{6}{|c|}{ Heterogeneity: $\mathrm{Tau}^{2}=0 ; \mathrm{Chi}^{2}=0.73, \mathrm{df}=3(\mathrm{P}=0.87) ; \mathrm{I}^{2}=0 \%$} \\
\hline Total $(95 \% \mathrm{Cl})$ & 623 & 452 & & $100 \%$ & $0.99[0.71,1.38]$ \\
\hline \multicolumn{6}{|c|}{ Total events: 101 (Growth factor), 86 (Placebo) } \\
\hline \multicolumn{6}{|c|}{ Heterogeneity: $\operatorname{Tau}^{2}=0 ; \mathrm{Chi}^{2}=8.95, \mathrm{df}=8(\mathrm{P}=0.35) ; \mathrm{I}^{2}=10.64 \%$} \\
\hline \multicolumn{6}{|c|}{ Test for overall effect: $\mathrm{Z}=0.05(\mathrm{P}=0.96)$} \\
\hline Test for subgroup di & $.02, \mathrm{df}=1(\mathrm{P}=0.6), \mathrm{I}$ & & & & \\
\hline
\end{tabular}

Analysis 1.3. Comparison 1 Growth factors versus placebo (or no therapy), Outcome 3 Limb amputation (any or not specified; at 1 year).

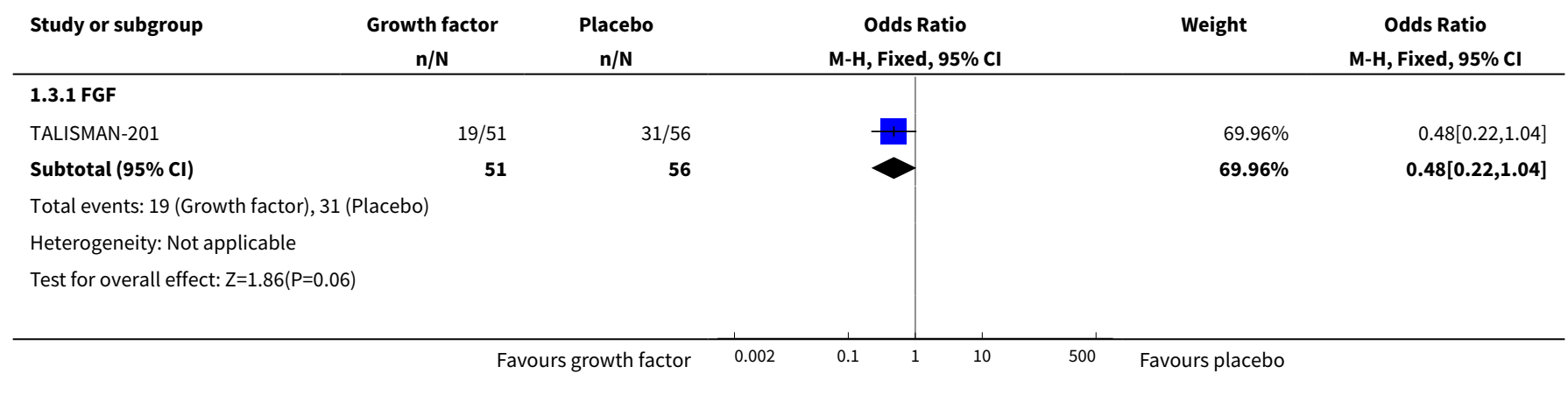




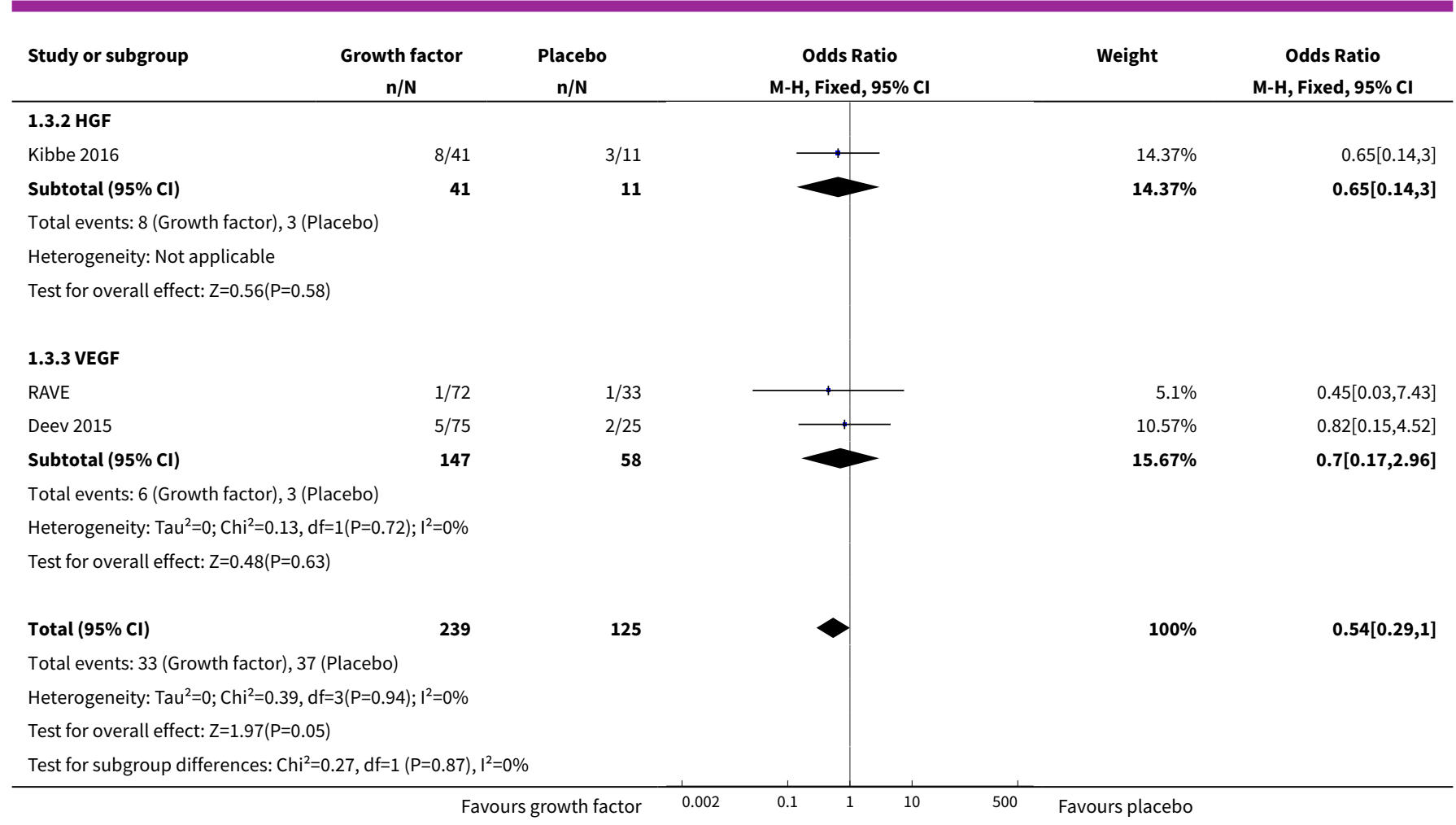

\section{Analysis 1.4. Comparison 1 Growth factors versus placebo (or no therapy), Outcome 4 Limb amputation (any or not specified; last data to 2 years).}

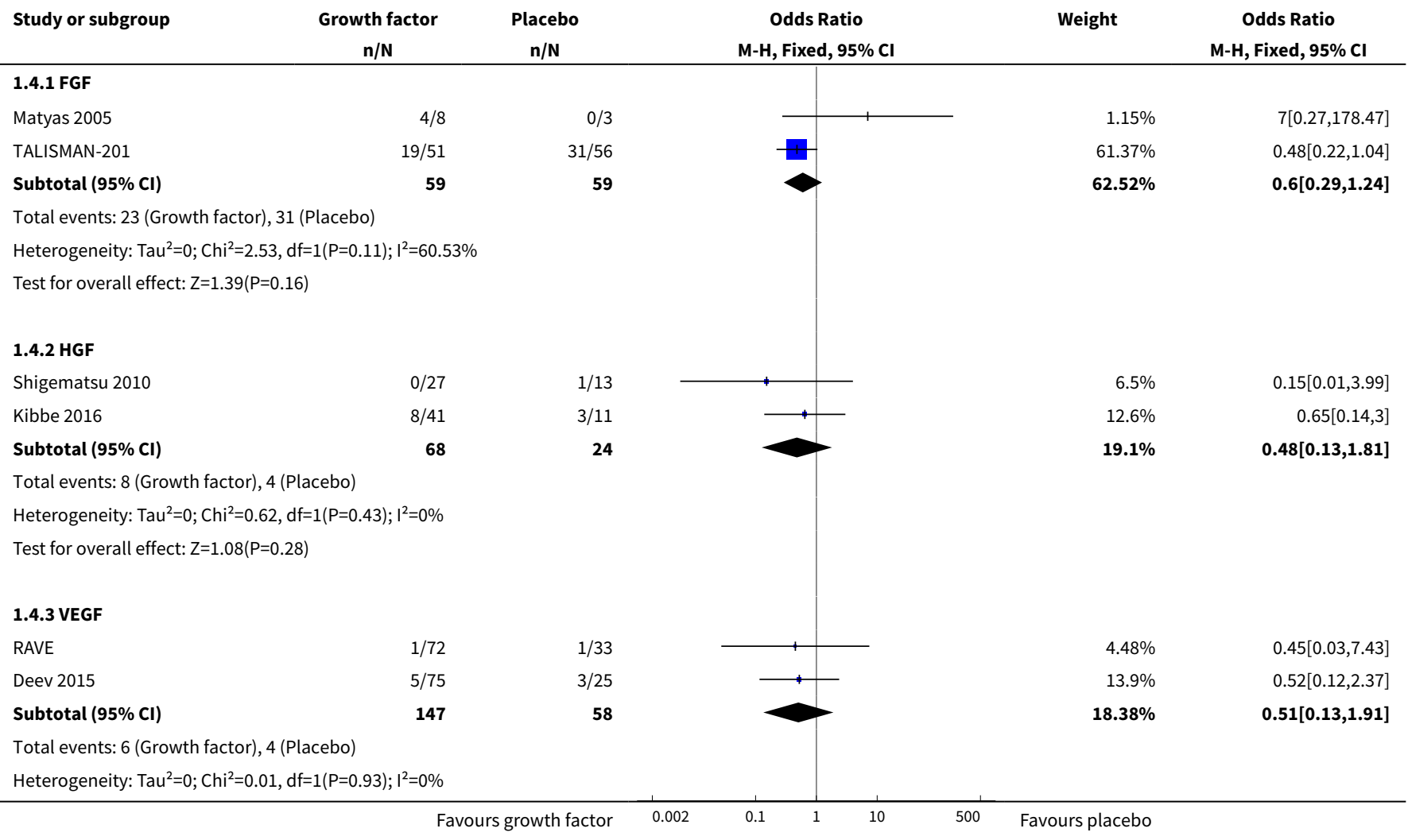




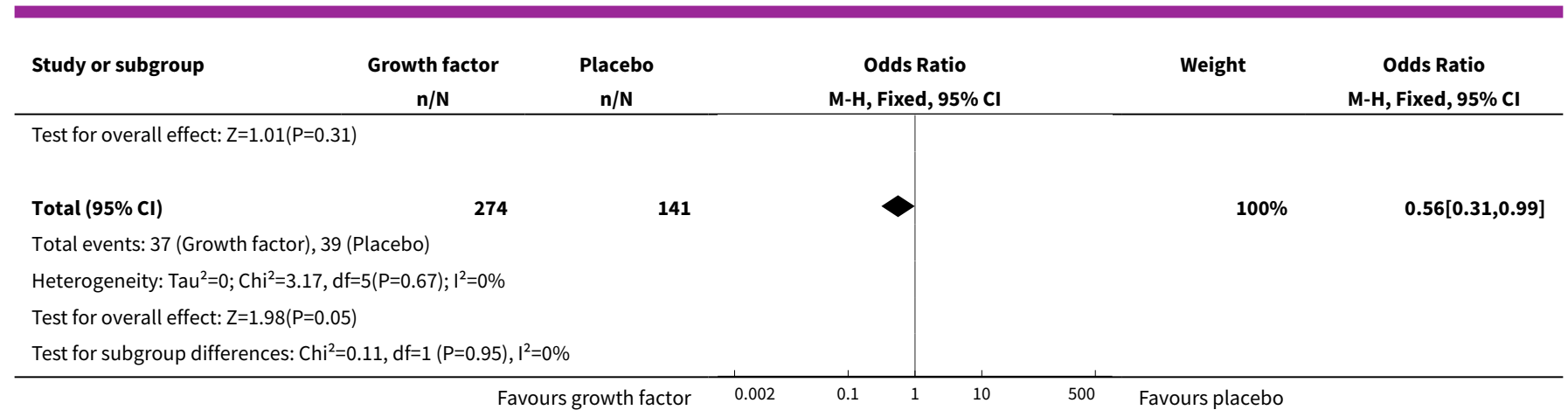

Analysis 1.5. Comparison 1 Growth factors versus placebo (or no therapy), Outcome 5 Death (of any cause; at 1 year).

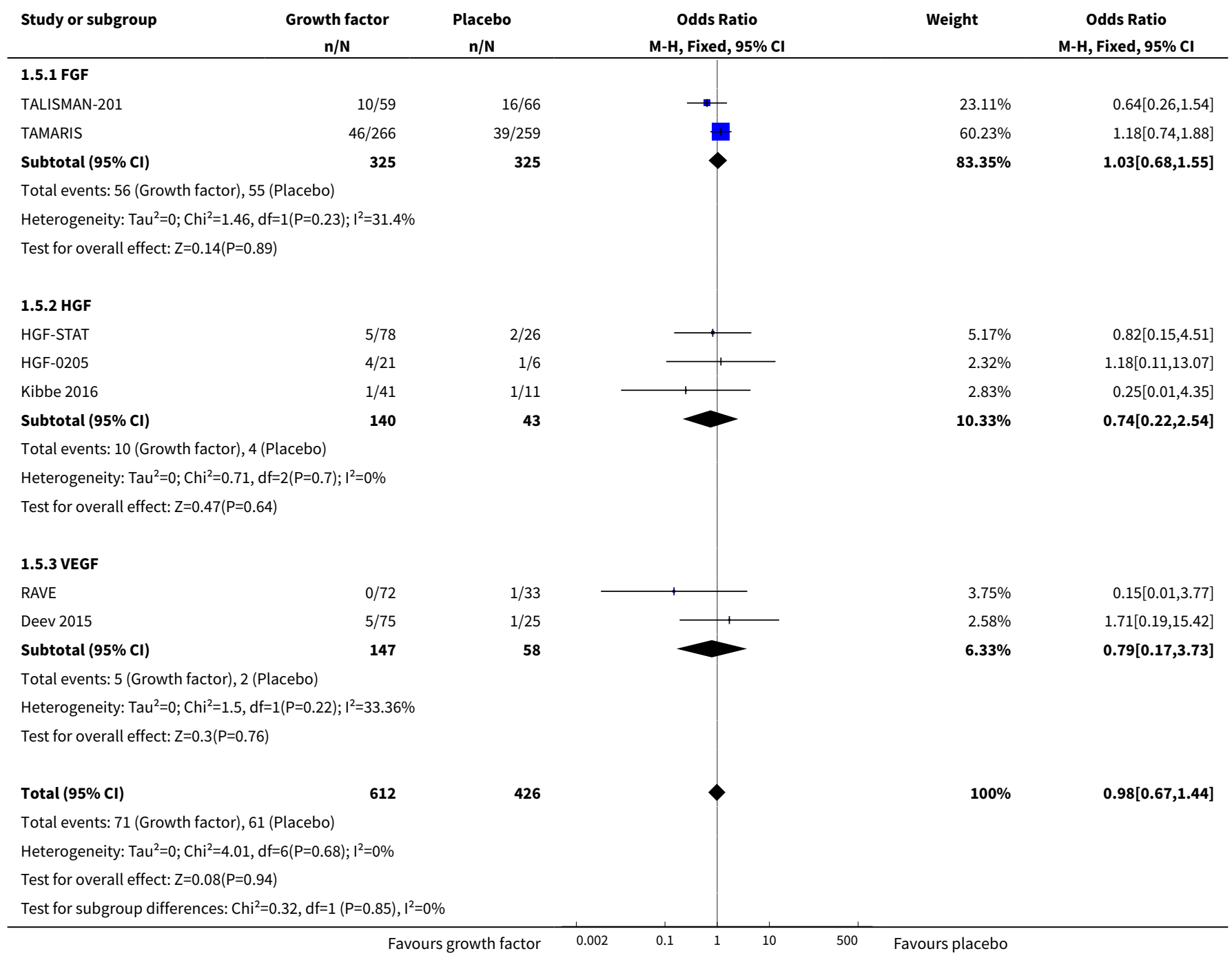


Analysis 1.6. Comparison 1 Growth factors versus placebo (or no therapy), Outcome 6 Death (from any cause; last data to 2 years).

\begin{tabular}{|c|c|c|c|c|c|}
\hline Study or subgroup & $\begin{array}{c}\text { Growth factor } \\
n / N\end{array}$ & $\begin{array}{c}\text { Placebo } \\
n / N\end{array}$ & $\begin{array}{c}\text { Odds Ratio } \\
\text { M-H, Fixed, 95\% Cl }\end{array}$ & Weight & $\begin{array}{c}\text { Odds Ratio } \\
\text { M-H, Fixed, 95\% Cl }\end{array}$ \\
\hline \multicolumn{6}{|l|}{ 1.6.1 FGF } \\
\hline Cooper 2001 & $1 / 16$ & $0 / 8$ & & $1 \%$ & $1.65[0.06,44.97]$ \\
\hline TRAFFIC & $1 / 127$ & $1 / 63$ & & $2.22 \%$ & $0.49[0.03,8]$ \\
\hline Matyas 2005 & $1 / 8$ & $0 / 3$ & - & $0.96 \%$ & $1.4[0.04,43.79]$ \\
\hline TALISMAN-201 & $10 / 59$ & $16 / 66$ & & $20.96 \%$ & $0.64[0.26,1.54]$ \\
\hline Subtotal $(95 \% \mathrm{Cl})$ & 476 & 399 & & $79.76 \%$ & $1.03[0.69,1.53]$ \\
\hline \multicolumn{6}{|c|}{ Total events: 59 (Growth factor), 56 (Placebo) } \\
\hline \multicolumn{6}{|c|}{ Heterogeneity: $\mathrm{Tau}^{2}=0 ; \mathrm{Chi}^{2}=1.83, \mathrm{df}=4(\mathrm{P}=0.77) ; \mathrm{I}^{2}=0 \%$} \\
\hline \multicolumn{6}{|c|}{ Test for overall effect: $Z=0.13(P=0.9)$} \\
\hline \multicolumn{6}{|l|}{ 1.6.2 HGF } \\
\hline HGF-0205 & $4 / 21$ & $1 / 6$ & & $2.1 \%$ & $1.18[0.11,13.07]$ \\
\hline Kibbe 2016 & $1 / 41$ & $1 / 11$ & & $2.57 \%$ & $0.25[0.01,4.35]$ \\
\hline Subtotal $(95 \% \mathrm{Cl})$ & 140 & 43 & & $9.37 \%$ & $0.74[0.22,2.54]$ \\
\hline \multicolumn{6}{|c|}{ Total events: 10 (Growth factor), 4 (Placebo) } \\
\hline \multicolumn{6}{|c|}{ Heterogeneity: $\mathrm{Tau}^{2}=0 ; \mathrm{Chi}^{2}=0.71, \mathrm{df}=2(\mathrm{P}=0.7) ; \mathrm{I}^{2}=0 \%$} \\
\hline \multicolumn{6}{|c|}{ Test for overall effect: $Z=0.47(P=0.64)$} \\
\hline \multicolumn{6}{|l|}{ 1.6.3 VEGF } \\
\hline Makinen 2002 & $2 / 35$ & $1 / 19$ & & $2.04 \%$ & $1.09[0.09,12.87]$ \\
\hline RAVE & $0 / 72$ & $1 / 33$ & & $3.4 \%$ & $0.15[0.01,3.77]$ \\
\hline Kusumanto 2006 & $2 / 27$ & $2 / 27$ & & $3.09 \%$ & $1[0.13,7.67]$ \\
\hline Deev 2015 & $5 / 75$ & $1 / 25$ & & $2.34 \%$ & $1.71[0.19,15.42]$ \\
\hline Subtotal $(95 \% \mathrm{CI})$ & 209 & 104 & & $10.87 \%$ & $0.91[0.3,2.74]$ \\
\hline \multicolumn{6}{|c|}{ Test for overall effect: $Z=0.18(P=0.86)$} \\
\hline Total $(95 \% \mathrm{Cl})$ & 825 & 546 & & $100 \%$ & $0.99[0.69,1.41]$ \\
\hline \multicolumn{6}{|c|}{ Total events: 78 (Growth factor), 65 (Placebo) } \\
\hline \multicolumn{6}{|c|}{ Heterogeneity: $\operatorname{Tau}^{2}=0 ; \mathrm{Chi}^{2}=4.39, \mathrm{df}=11(\mathrm{P}=0.96) ; \mathrm{I}^{2}=0 \%$} \\
\hline \multicolumn{6}{|c|}{ Test for overall effect: $Z=0.07(P=0.94)$} \\
\hline Test for subgroup dif & 26, $d f=1(P=0.88)$, & & & & \\
\hline
\end{tabular}

Analysis 1.7. Comparison 1 Growth factors versus placebo (or no therapy), Outcome 7 Adverse events (serious; only aggregate data, up to 2 years).

\begin{tabular}{|c|c|c|c|c|c|}
\hline Study or subgroup & $\begin{array}{c}\text { Growth factor } \\
n / N\end{array}$ & $\begin{array}{c}\text { Placebo } \\
n / N\end{array}$ & $\begin{array}{c}\text { Odds Ratio } \\
\text { M-H, Fixed, } 95 \% \mathrm{CI}\end{array}$ & Weight & $\begin{array}{c}\text { Odds Ratio } \\
\text { M-H, Fixed, } 95 \% \mathrm{Cl}\end{array}$ \\
\hline \multicolumn{6}{|l|}{ 1.7.1 FGF } \\
\hline TALISMAN-201 & $40 / 57$ & $49 / 61$ & $\longrightarrow$ & $30.76 \%$ & $0.58[0.25,1.35]$ \\
\hline TAMARIS & $24 / 266$ & $15 / 257$ & - & $30.24 \%$ & $1.6[0.82,3.12]$ \\
\hline Subtotal $(95 \% \mathrm{Cl})$ & 323 & 318 & & $61.01 \%$ & $1.08[0.65,1.81]$ \\
\hline \multicolumn{6}{|c|}{ Total events: 64 (Growth factor), 64 (Placebo) } \\
\hline
\end{tabular}




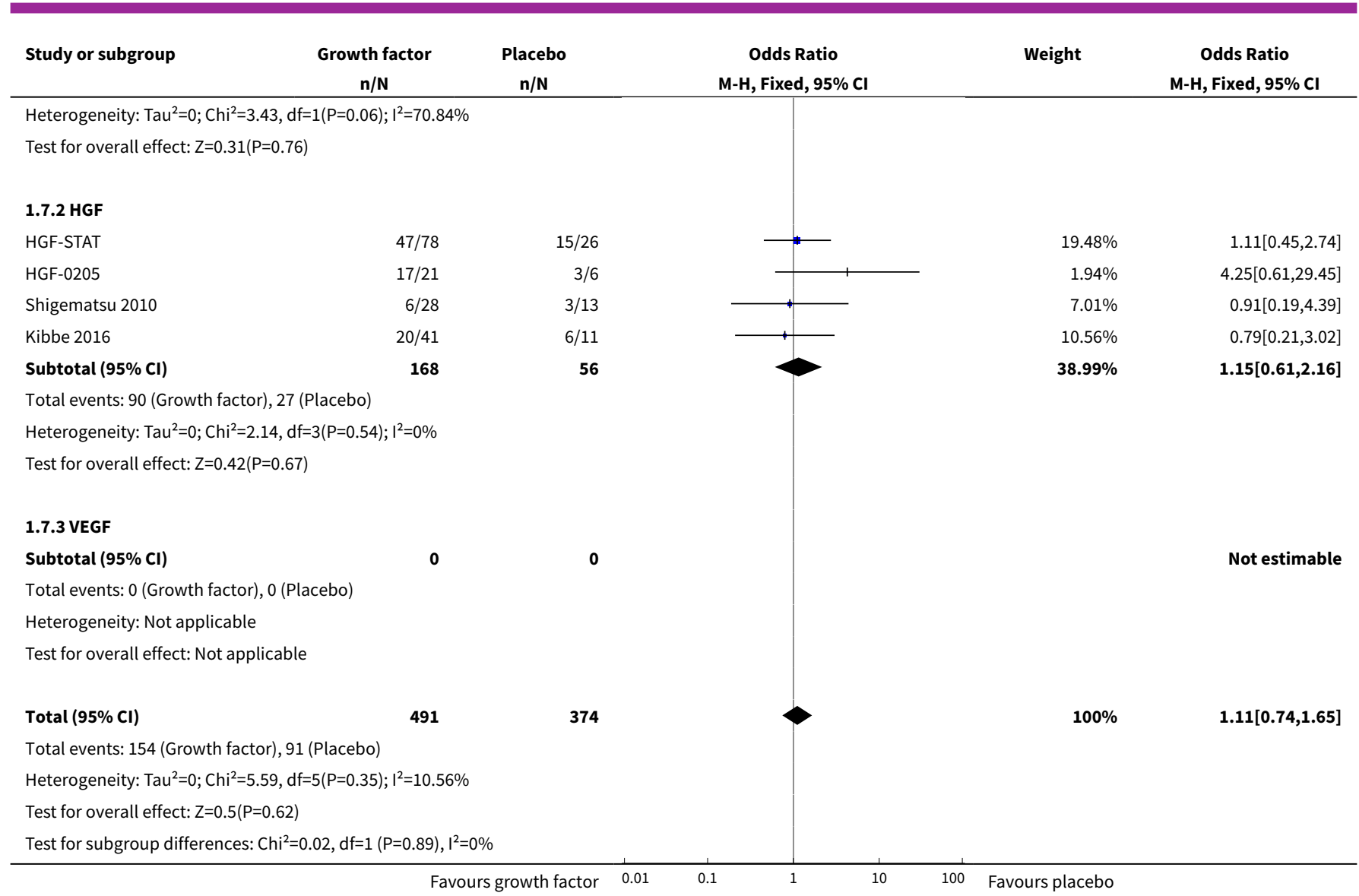

Analysis 1.8. Comparison 1 Growth factors versus placebo (or no therapy), Outcome 8 Adverse events (serious; incl. data for single events, up to 2 years).

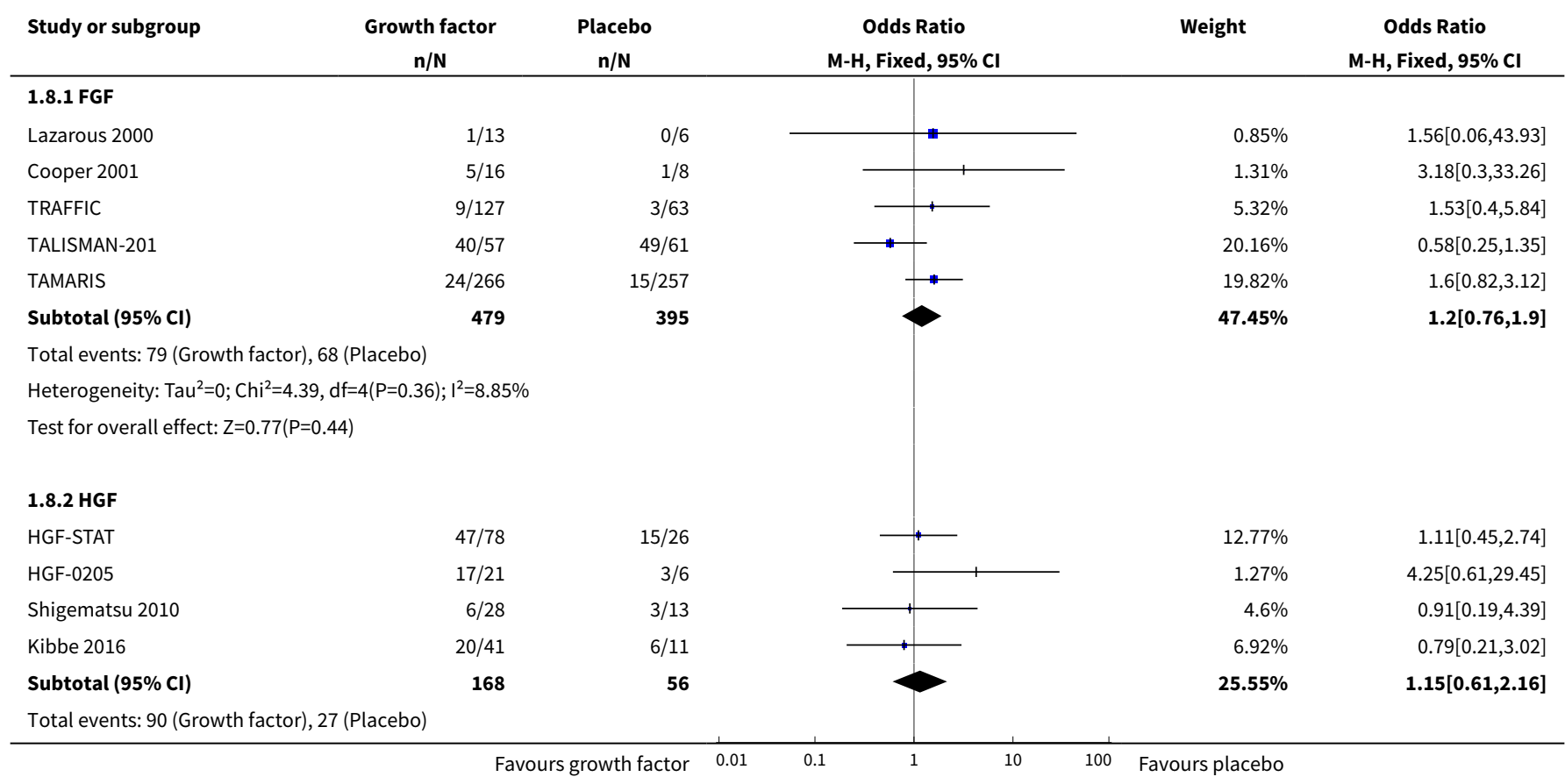




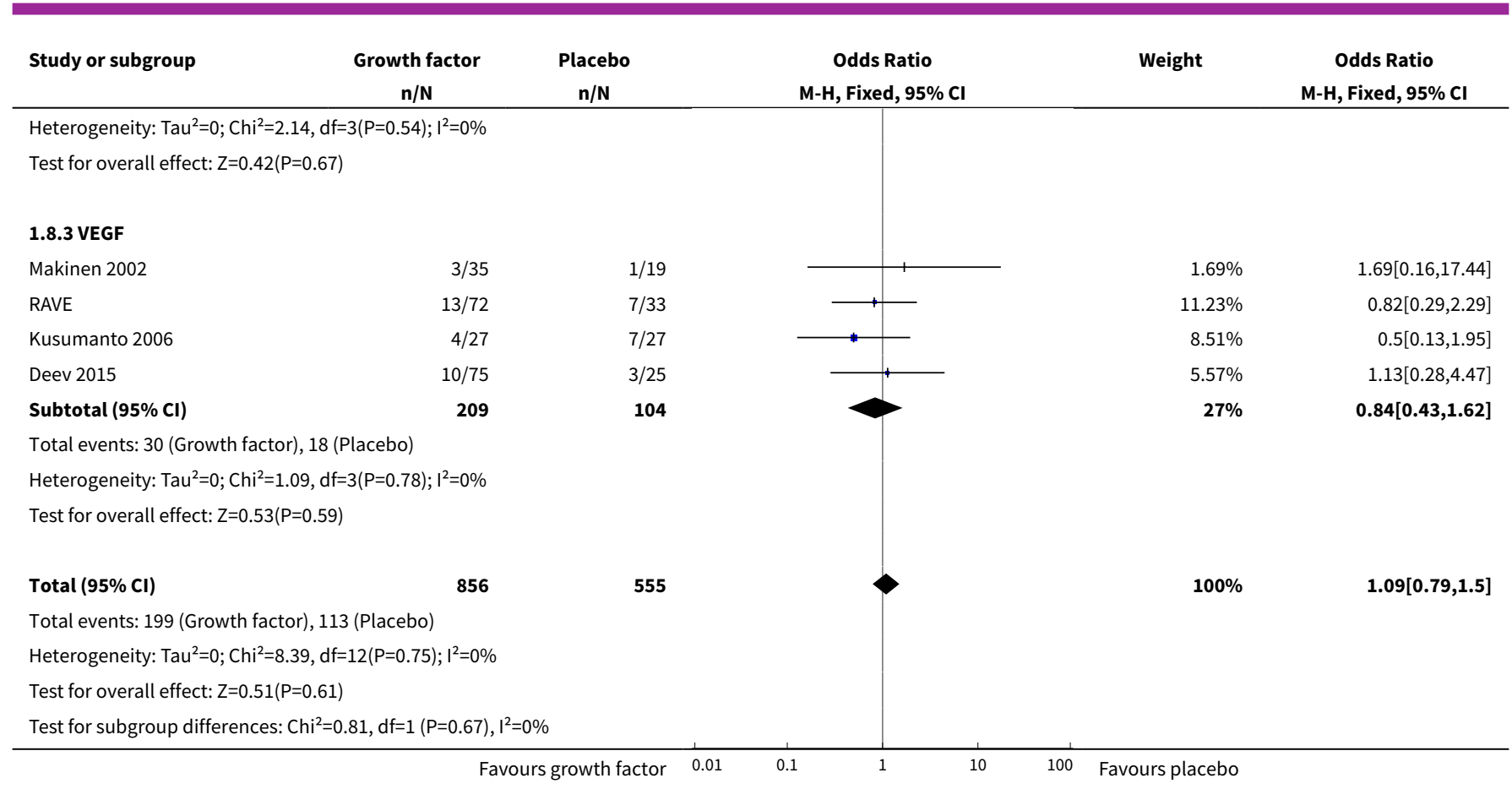

\section{Analysis 1.9. Comparison 1 Growth factors versus placebo (or no therapy), Outcome 9 Adverse events (any; only aggregated data, up to 2 years).}

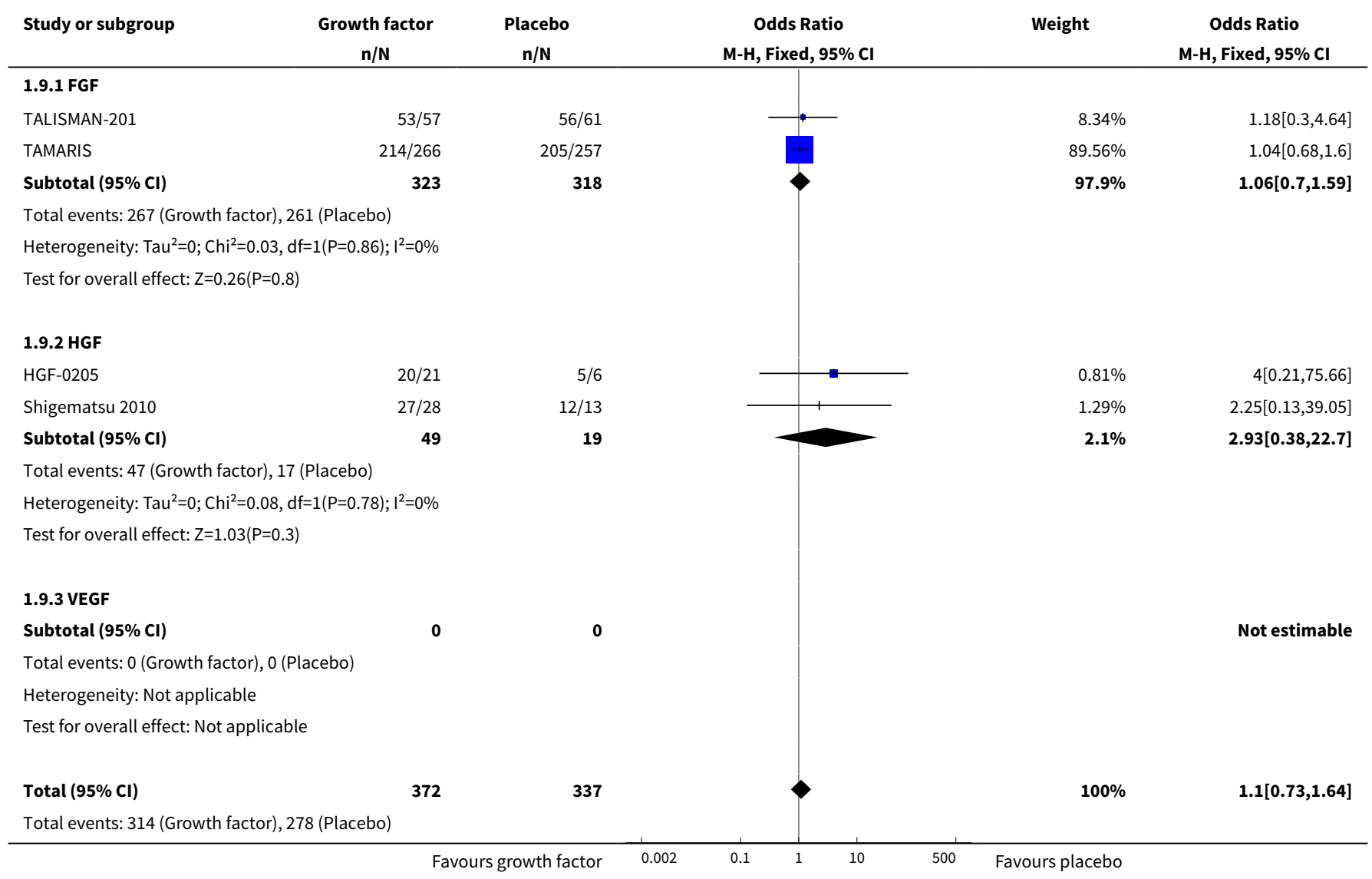




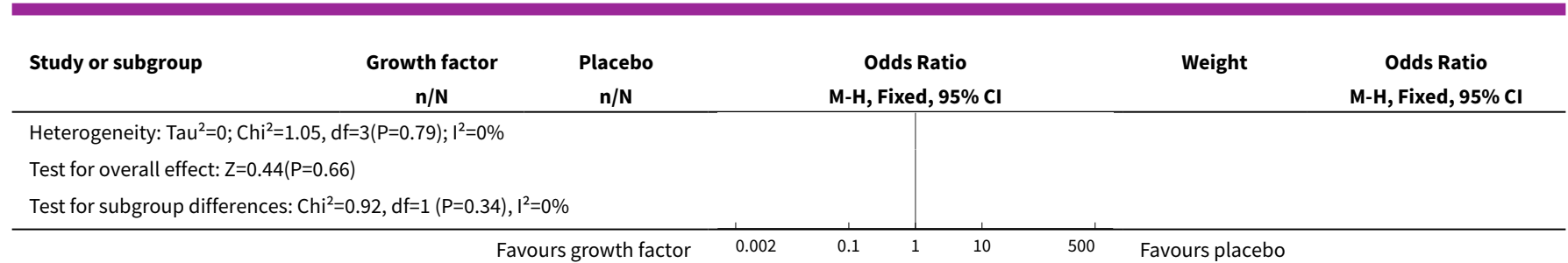

Analysis 1.10. Comparison 1 Growth factors versus placebo (or no therapy), Outcome 10 Adverse events (any; incl. data for single events, up to 2 years).

\begin{tabular}{|c|c|c|c|c|c|}
\hline Study or subgroup & $\begin{array}{c}\text { Growth factor } \\
\qquad / \mathbf{N}\end{array}$ & $\begin{array}{c}\text { Placebo } \\
n / N\end{array}$ & $\begin{array}{c}\text { Odds Ratio } \\
\text { M-H, Fixed, 95\% Cl }\end{array}$ & Weight & $\begin{array}{c}\text { Odds Ratio } \\
\text { M-H, Fixed, 95\% Cl }\end{array}$ \\
\hline \multicolumn{6}{|l|}{ 1.10.1 FGF } \\
\hline Lazarous 2000 & $3 / 13$ & $0 / 6$ & $*$ & $0.63 \%$ & $4.33[0.19,98.18]$ \\
\hline Cooper 2001 & $13 / 16$ & $1 / 8$ & 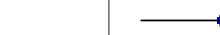 & $0.32 \%$ & $30.33[2.64,348.92]$ \\
\hline TRAFFIC & $32 / 127$ & $7 / 63$ & $\rightarrow$ & $8.85 \%$ & $2.69[1.12,6.51]$ \\
\hline TALISMAN-201 & $53 / 57$ & $56 / 61$ & T: & $4.8 \%$ & $1.18[0.3,4.64]$ \\
\hline Subtotal $(95 \% \mathrm{Cl})$ & 479 & 395 & & $66.13 \%$ & $1.45[1.02,2.06]$ \\
\hline \multicolumn{6}{|c|}{ Total events: 315 (Growth factor), 269 (Placebo) } \\
\hline \multicolumn{6}{|c|}{ Heterogeneity: $\mathrm{Tau}^{2}=0 ; \mathrm{Chi}^{2}=10.65, \mathrm{df}=4(\mathrm{P}=0.03) ; \mathrm{I}^{2}=62.43 \%$} \\
\hline \multicolumn{6}{|c|}{ Test for overall effect: $Z=2.06(P=0.04)$} \\
\hline \multicolumn{6}{|l|}{ 1.10.2 HGF } \\
\hline HGF-0205 & $20 / 21$ & $5 / 6$ & & $0.47 \%$ & $4[0.21,75.66]$ \\
\hline Shigematsu 2010 & $27 / 28$ & $12 / 13$ & & $0.74 \%$ & $2.25[0.13,39.05]$ \\
\hline Kibbe 2016 & $40 / 41$ & $7 / 11$ & $\longrightarrow$ & $0.34 \%$ & $22.86[2.22,235.82]$ \\
\hline Subtotal $(95 \% \mathrm{Cl})$ & 168 & 56 & & $8.02 \%$ & $2.77[1.24,6.22]$ \\
\hline \multicolumn{6}{|c|}{ Total events: 151 (Growth factor), 43 (Placebo) } \\
\hline \multicolumn{6}{|c|}{ Heterogeneity: Tau $^{2}=0 ; \mathrm{Chi}^{2}=4.1, \mathrm{df}=3(\mathrm{P}=0.25) ; \mathrm{I}^{2}=26.79 \%$} \\
\hline \multicolumn{6}{|c|}{ Test for overall effect: $Z=2.47(P=0.01)$} \\
\hline \multicolumn{6}{|l|}{ 1.10.3 VEGF } \\
\hline Makinen 2002 & $5 / 35$ & $1 / 19$ & + & $1.4 \%$ & $3[0.32,27.76]$ \\
\hline RAVE & $30 / 72$ & $10 / 33$ & + & $10.11 \%$ & $1.64[0.68,3.95]$ \\
\hline Kusumanto 2006 & $10 / 27$ & $12 / 27$ & - & $9.55 \%$ & $0.74[0.25,2.19]$ \\
\hline Deev 2015 & $12 / 75$ & $3 / 25$ & 1 & $4.78 \%$ & $1.4[0.36,5.42]$ \\
\hline \multicolumn{6}{|c|}{ Heterogeneity: $\operatorname{Tau}^{2}=0 ; \mathrm{Chi}^{2}=1.88, \mathrm{df}=3(\mathrm{P}=0.6) ; \mathrm{I}^{2}=0 \%$} \\
\hline \multicolumn{6}{|c|}{ Test for overall effect: $Z=0.98(P=0.33)$} \\
\hline Total $(95 \% \mathrm{Cl})$ & 856 & 555 & $\diamond$ & $100 \%$ & $1.52[1.15,2.02]$ \\
\hline \multicolumn{6}{|c|}{ Total events: 523 (Growth factor), 338 (Placebo) } \\
\hline \multicolumn{6}{|c|}{ Heterogeneity: $\mathrm{Tau}^{2}=0 ; \mathrm{Chi}^{2}=18.72, \mathrm{df}=12(\mathrm{P}=0.1) ; \mathrm{I}^{2}=35.9 \%$} \\
\hline \multicolumn{6}{|c|}{ Test for overall effect: $Z=2.93(P=0)$} \\
\hline Test for subgroup dif & $39, \mathrm{df}=1(\mathrm{P}=0.3), \mathrm{I}^{2}$ & & & & \\
\hline
\end{tabular}


Analysis 1.11. Comparison 1 Growth factors versus placebo (or no therapy), Outcome 11 Walking ability (change in peak walking time [min]; last data to 6 months).

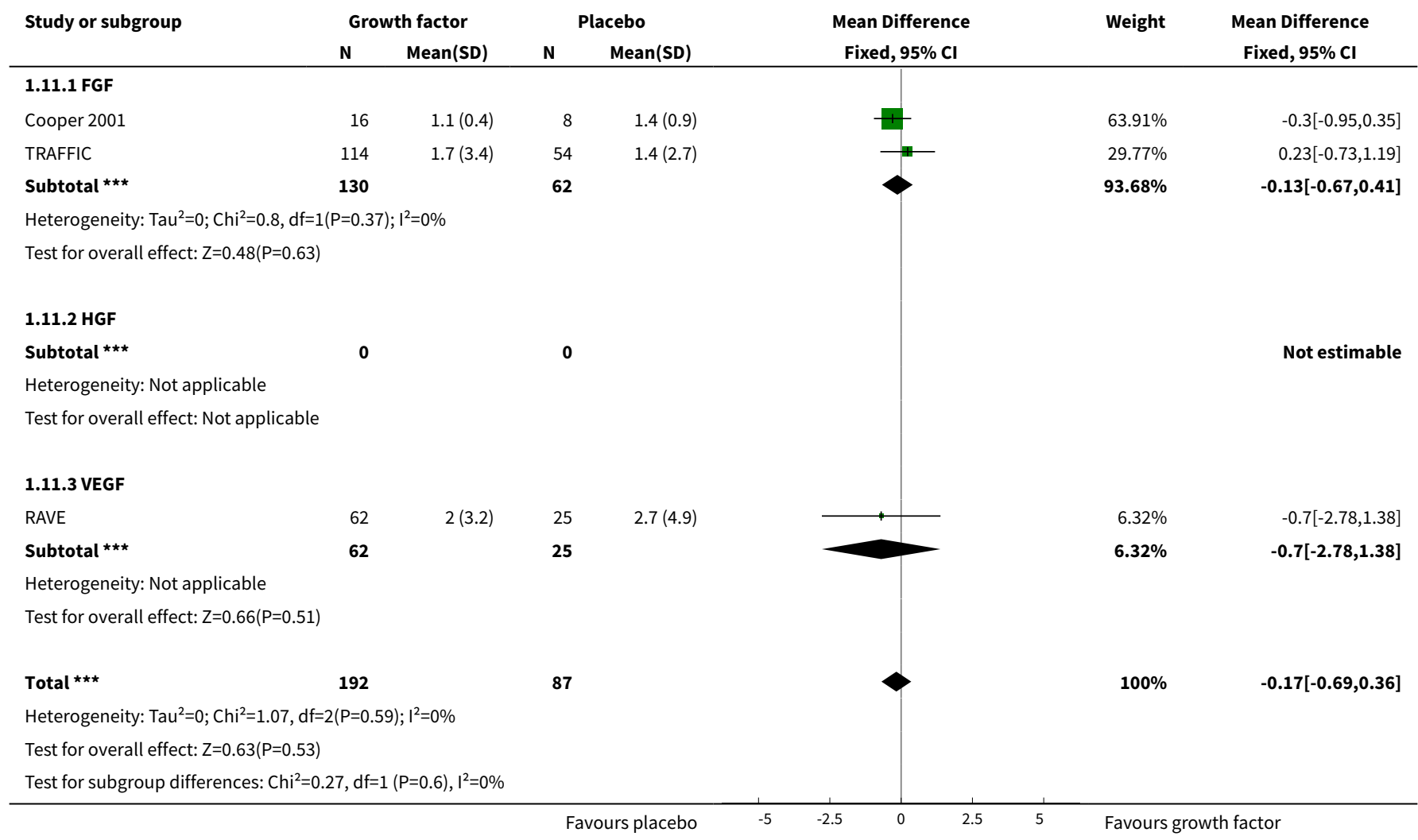

Analysis 1.12. Comparison 1 Growth factors versus placebo (or no therapy), Outcome 12 Walking ability (change in claudication onset time [min]; last data to 6 months).

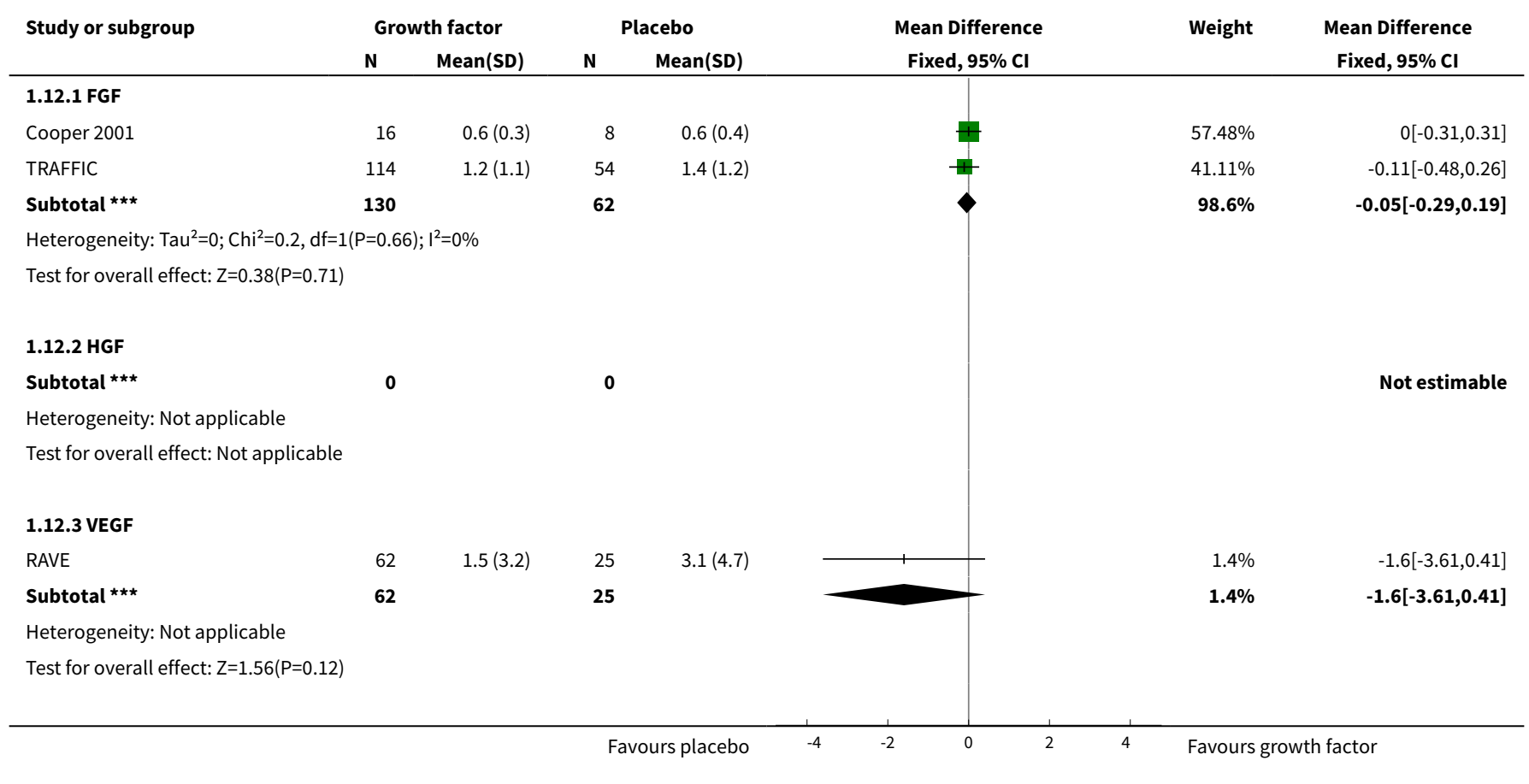




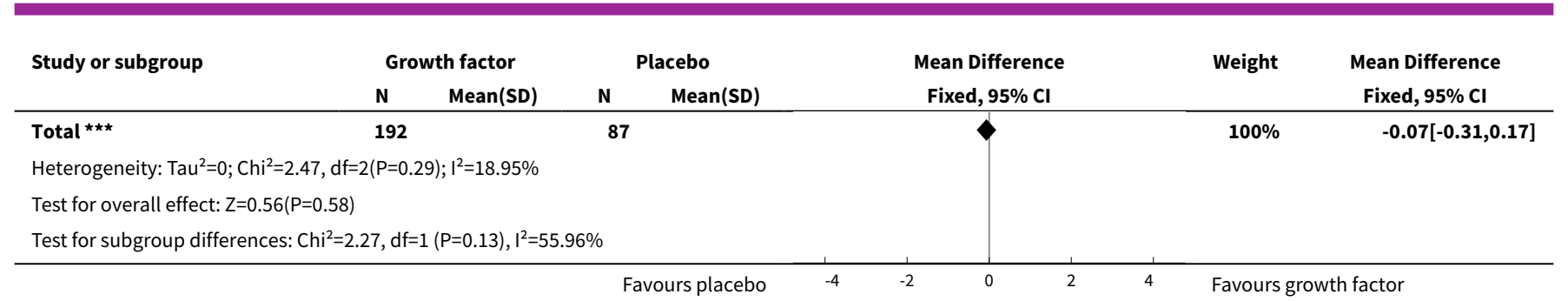

Analysis 1.13. Comparison 1 Growth factors versus placebo (or no therapy), Outcome 13 Haemodynamic measures (change in ABI; last data to 6 months).

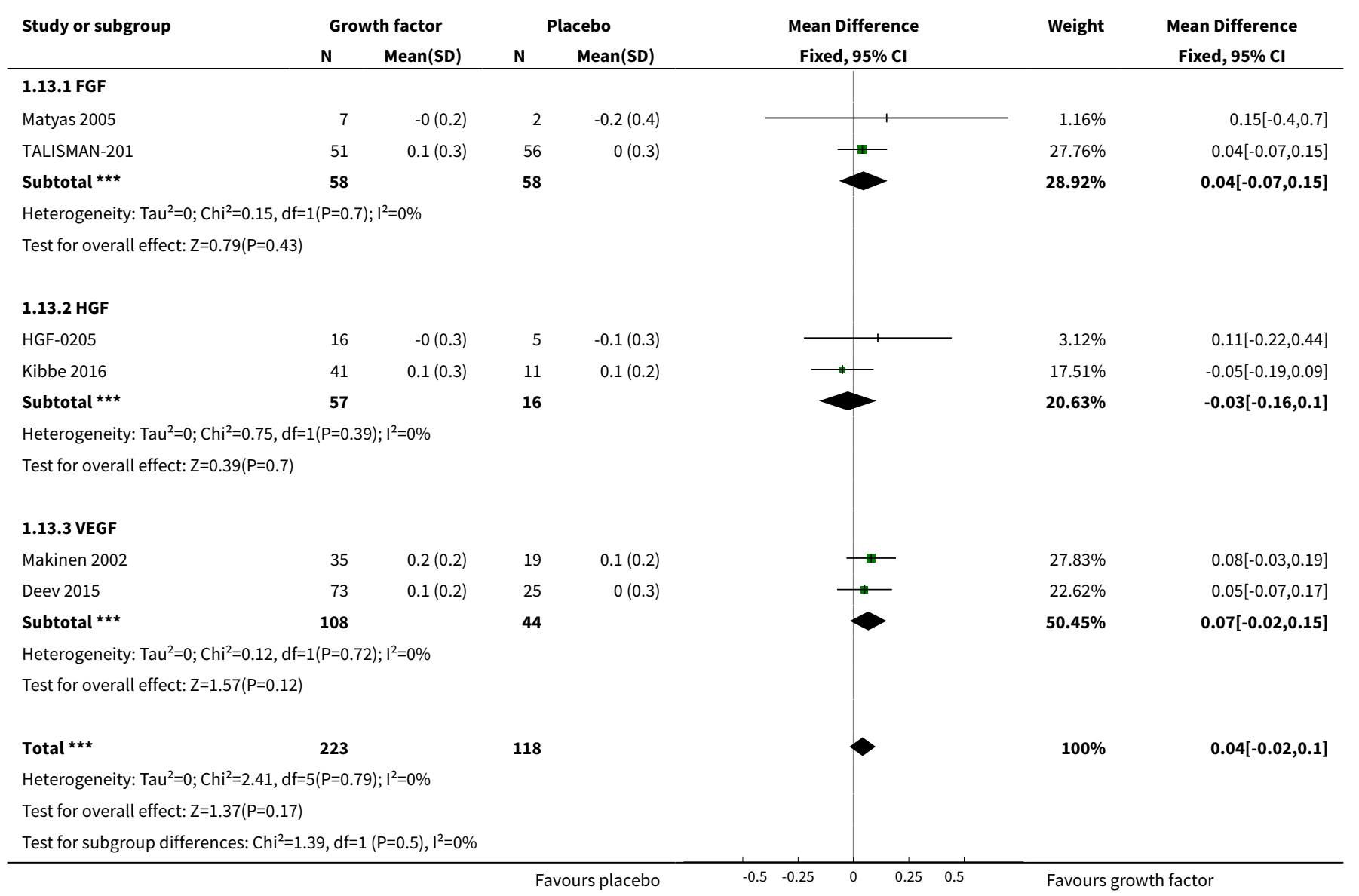

Analysis 1.14. Comparison 1 Growth factors versus placebo (or no therapy), Outcome 14 Haemodynamic measures (change in TBI; last data to 6 months).

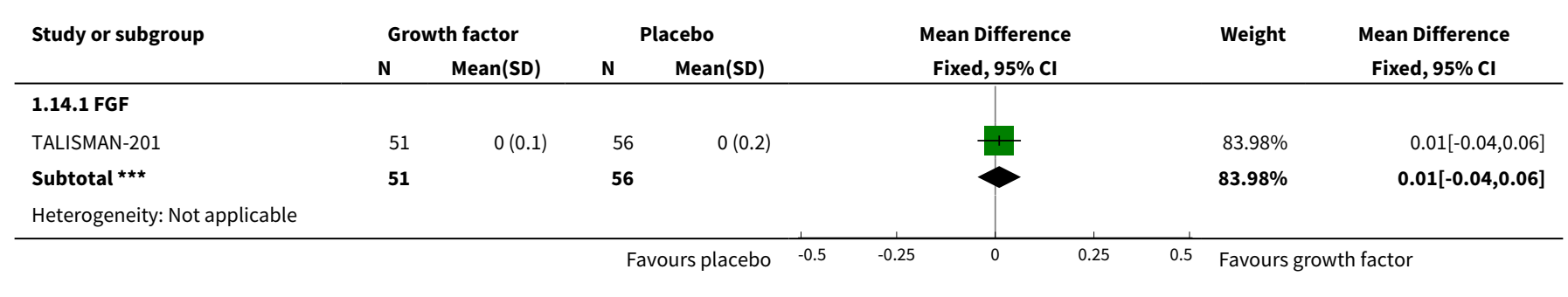




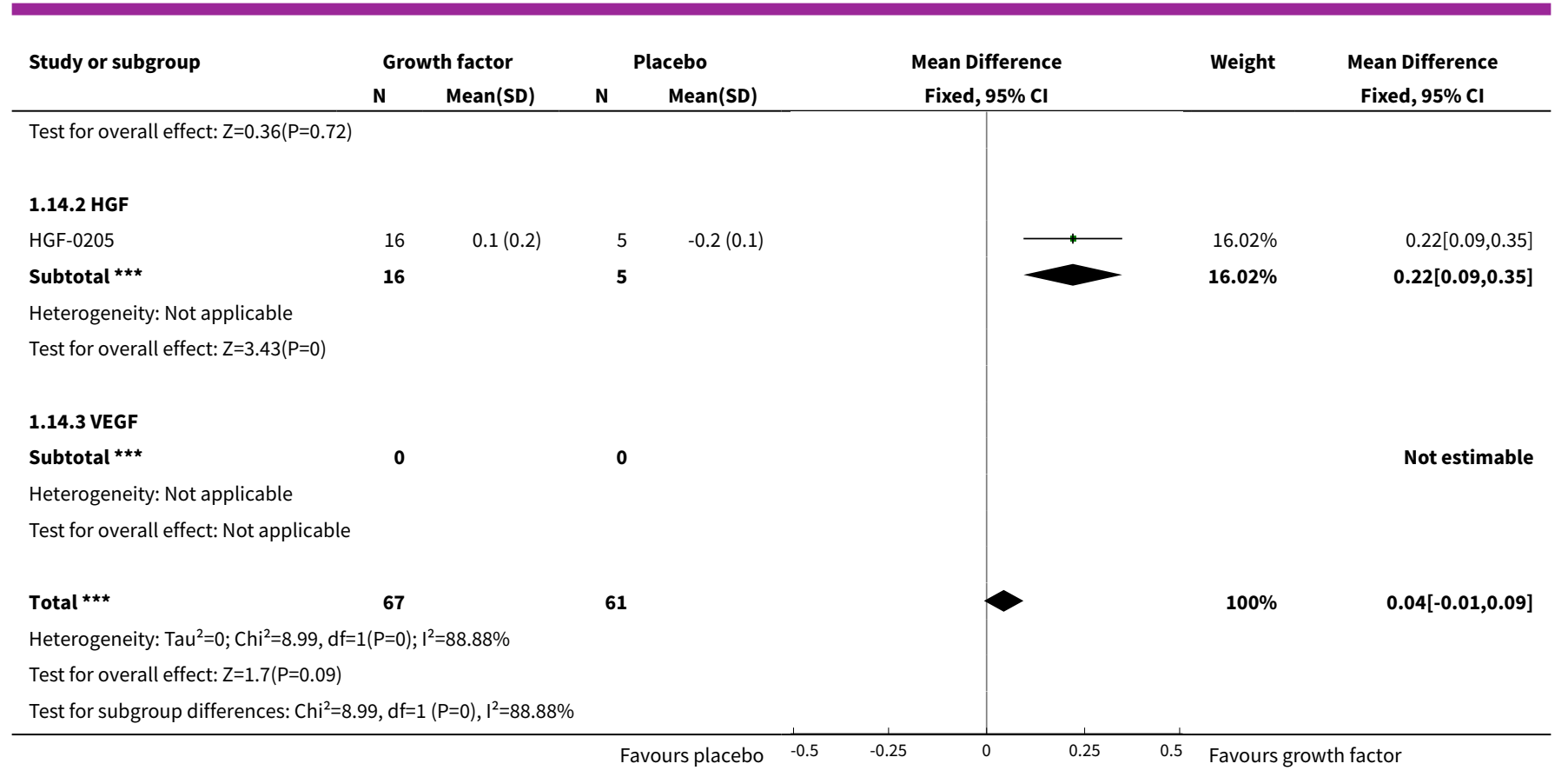

\section{Analysis 1.15. Comparison 1 Growth factors versus placebo (or no therapy), Outcome 15 Ulceration (complete ulcer healing; last data to 1 year).}

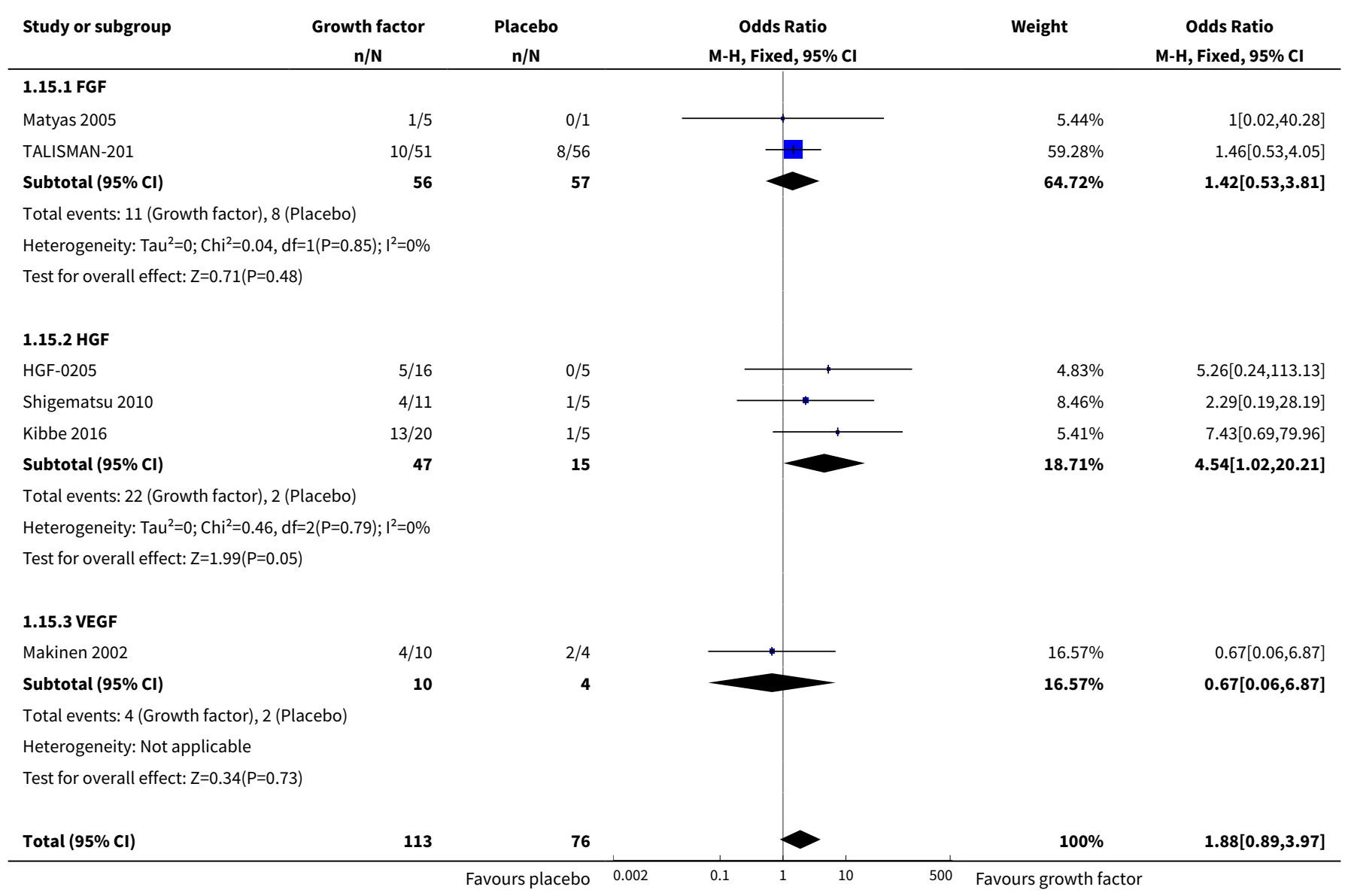




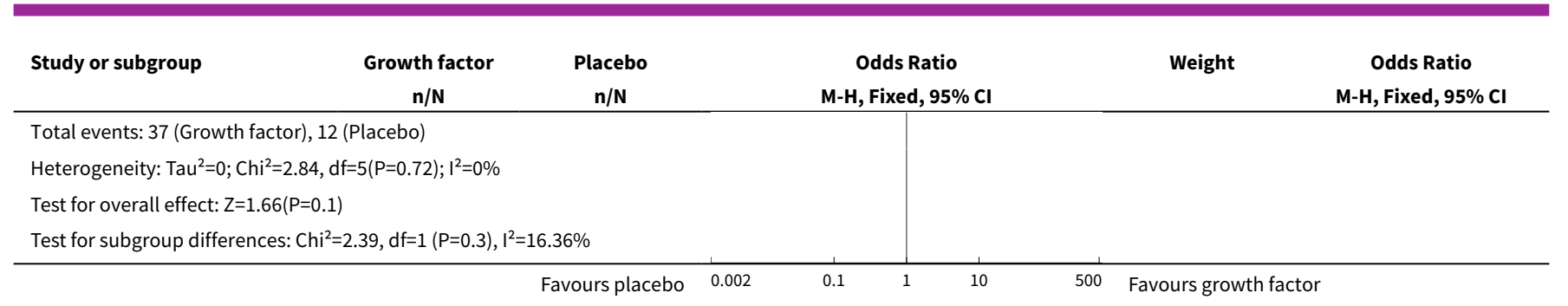

\section{Analysis 1.16. Comparison 1 Growth factors versus placebo (or no therapy), Outcome 16 Ulceration (improvement in ulcer size; last data to 1 year).}

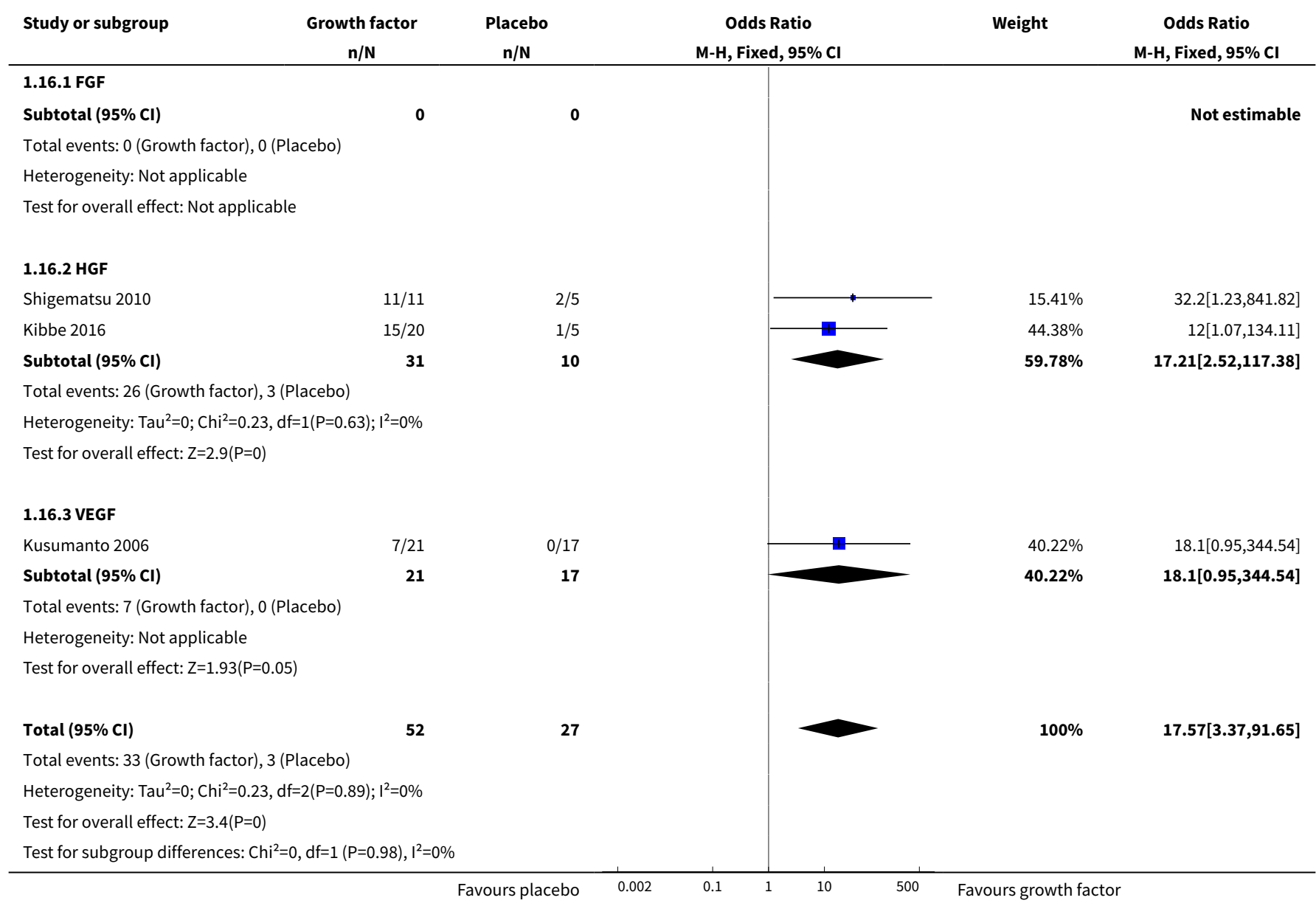

Analysis 1.17. Comparison 1 Growth factors versus placebo (or no therapy), Outcome 17 Rest pain (change on $10 \mathrm{~cm}$ VAS; last data to1 year).

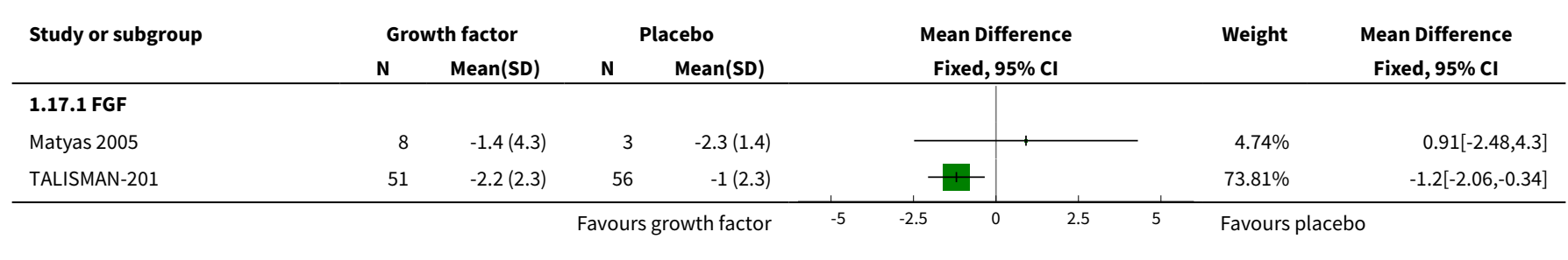




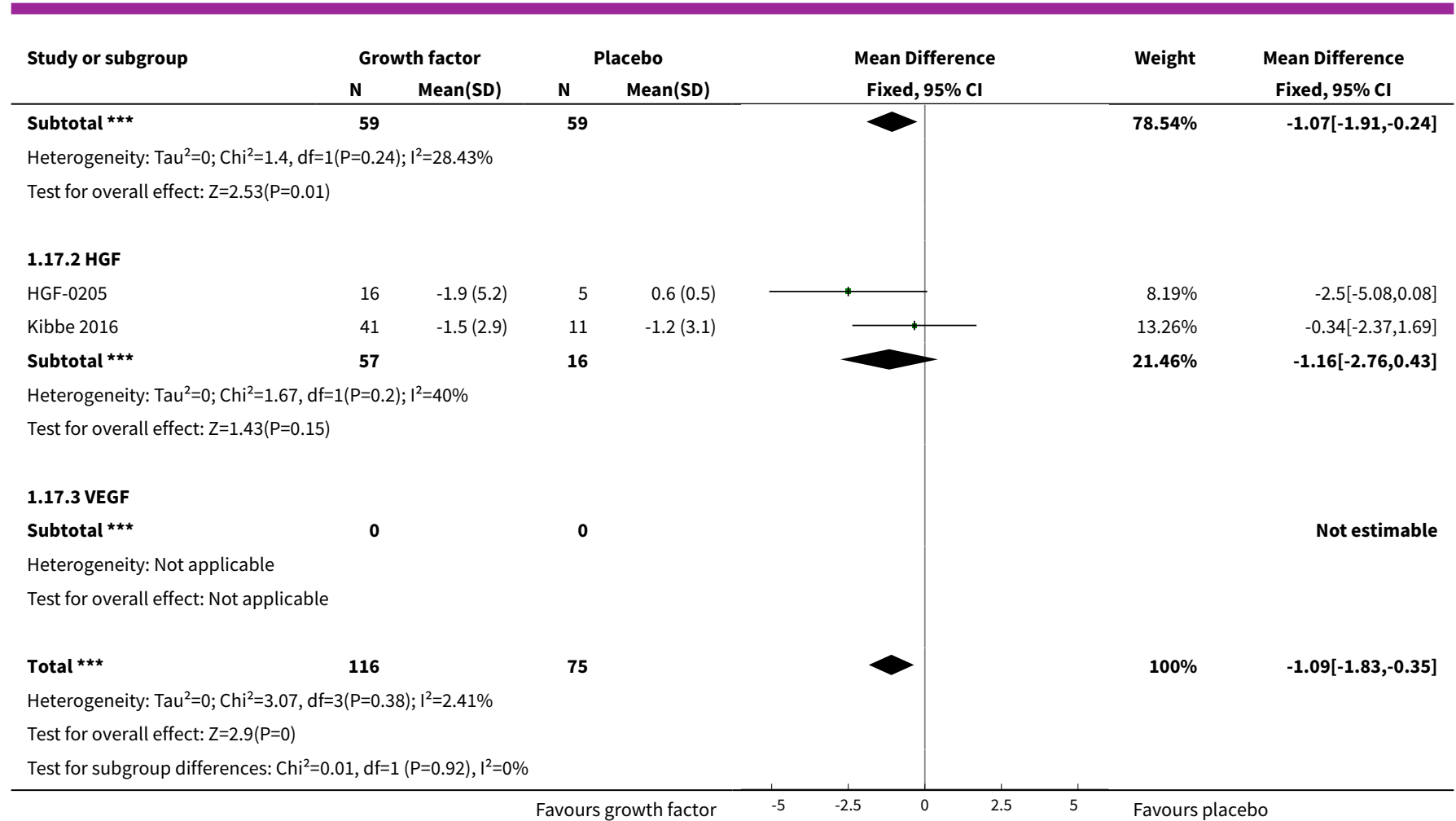

Analysis 1.18. Comparison 1 Growth factors versus placebo (or no therapy), Outcome 18 Rest pain (improvement; last data to 1 year).

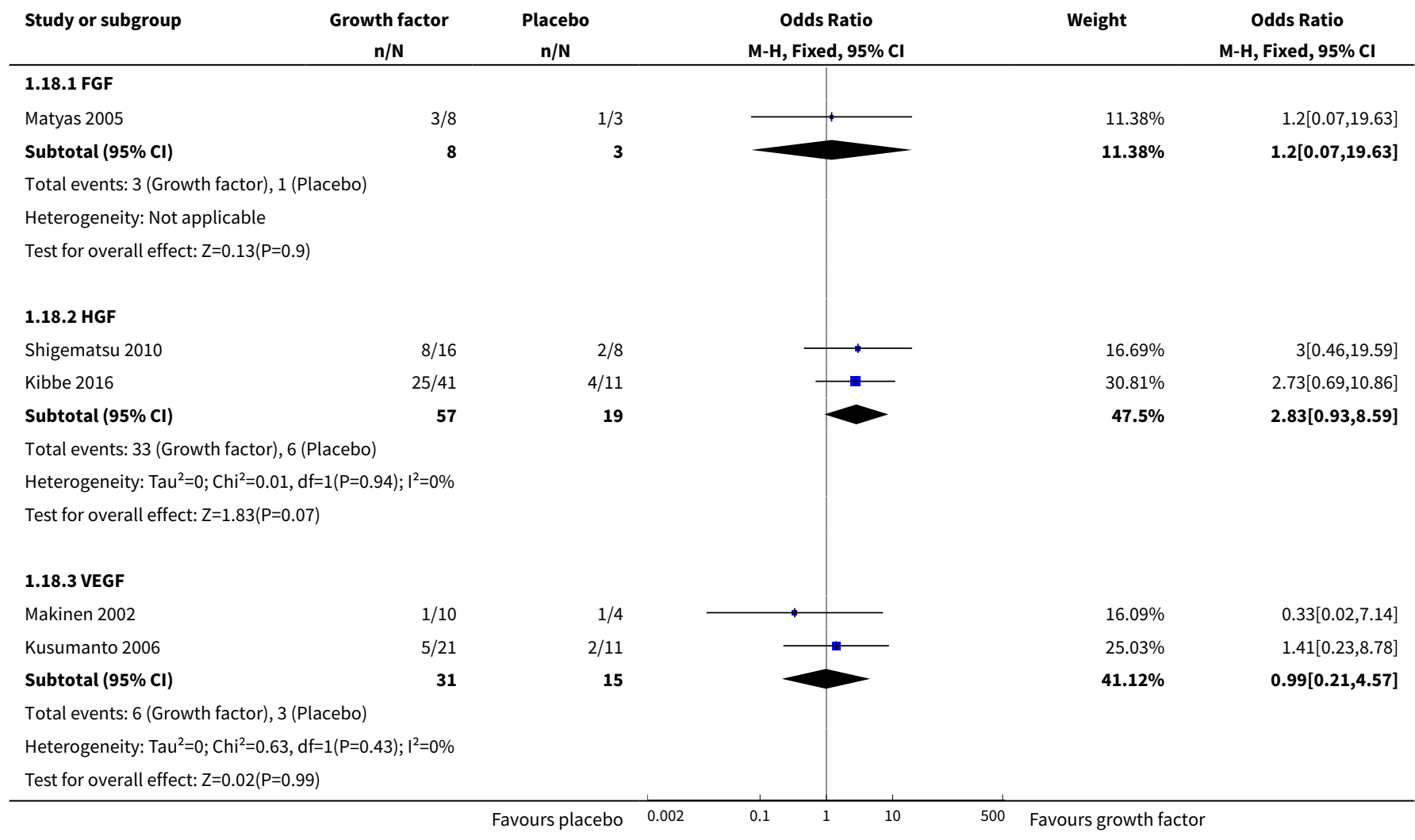




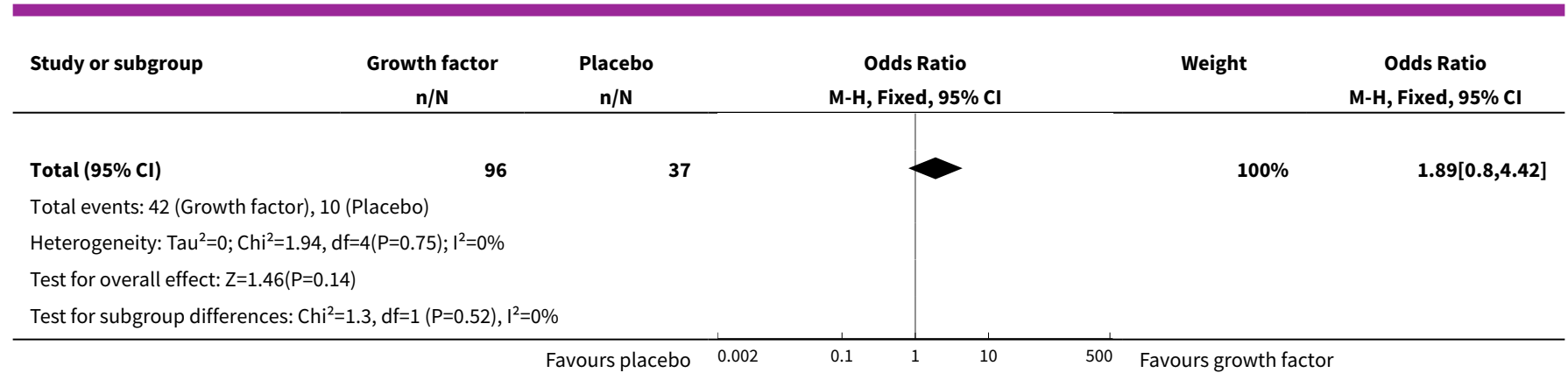

ADDITIONAL TABLES

Table 1. Overview of the studies

\begin{tabular}{|c|c|c|c|c|}
\hline Trial & N participants & Indication & Intervention & Placebo \\
\hline \multicolumn{5}{|c|}{ Fibroblast growth factor } \\
\hline \multirow[t]{3}{*}{ Lazarous 2000} & 19 & Intermittent claudication & $1 \times 10 \mu \mathrm{g} / \mathrm{kg} \mathrm{b}-\mathrm{FGF}, \mathrm{n}=4$ & $\mathrm{n}=6$ \\
\hline & & & $1 \times 30 \mu \mathrm{g} / \mathrm{kg}$ b-FGF, $\mathrm{n}=5$ & \\
\hline & & & $2 \times 30 \mu \mathrm{g} / \mathrm{kg}$ b-FGF, $\mathrm{n}=4$ & \\
\hline Cooper 2001 & 24 (plan 108) & Intermittent claudication & $6 \times 2 \mu \mathrm{g} / \mathrm{kg}$ b-FGF, $\mathrm{n}=16$ & $\mathrm{n}=8$ \\
\hline \multirow[t]{2}{*}{ TRAFFIC } & 190 & Intermittent claudication & $1 \times 30 \mu \mathrm{g} / \mathrm{kg}$ FGF-2, $\mathrm{n}=66$ & $\mathrm{n}=63$ \\
\hline & & & $2 \times 30 \mu \mathrm{g} / \mathrm{kg}$ FGF-2, $\mathrm{n}=61$ & \\
\hline TALISMAN-201 & 125 & Critical limb ischaemia & $16 \mathrm{mg}(4 \times 4 \mathrm{mg}) \mathrm{NV} 1 \mathrm{FGF}, \mathrm{n}=59$ & $\mathrm{n}=66$ \\
\hline TALISMAN-202a & 71 & Critical limb ischaemia & 2-16 mg [5 groups] NV1FGF, $n=?$ & $\mathrm{n}=$ ? \\
\hline \multirow[t]{2}{*}{ TALISMAN-211 $a$} & 36 & Critical limb ischaemia & $16 \mathrm{mg}(4 \times 4 \mathrm{mg}) \mathrm{NV} 1 \mathrm{FGF}, \mathrm{n}=?$ & $\mathrm{n}=$ ? \\
\hline & & & $32 \mathrm{mg}(4 \times 8 \mathrm{mg}) \mathrm{NV} 1 \mathrm{FGF}, \mathrm{n}=?$ & \\
\hline TAMARIS & 525 & Critical limb ischaemia & $16 \mathrm{mg}(4 \times 4 \mathrm{mg}) \mathrm{NV} 1 \mathrm{FGF}, \mathrm{n}=266$ & $n=259$ \\
\hline \multirow[t]{3}{*}{ Matyas 2005} & $11+2^{b}($ plan 28$)$ & Critical limb ischaemia & $2.87 \times 10^{8}$ Ad5FGF-4, $n=3+2^{b}$ & $\mathrm{n}=3$ \\
\hline & & & $2.87 \times 10^{9}$ Ad5FGF- $4, n=3$ & \\
\hline & & & $2.87 \times 10^{10}$ Ad5FGF-4, $n=2$ & \\
\hline
\end{tabular}

\section{Hepatocyte growth factors}

\begin{tabular}{|c|c|c|c|c|}
\hline \multirow[t]{3}{*}{ HGF-STAT } & 104 & Critical limb ischaemia & $3 \times 0.4 \mathrm{mg}$ AMG0001, $\mathrm{n}=26$ & $\mathrm{n}=26$ \\
\hline & & & $2 \times 4.0 \mathrm{mg}$ AMG0001, $\mathrm{n}=25$ & \\
\hline & & & $3 \times 4.0 \mathrm{mg}$ AMG0001, $\mathrm{n}=27$ & \\
\hline
\end{tabular}


Table 1. Overview of the studies (Continued)

\begin{tabular}{|c|c|c|c|c|}
\hline HGF-0205 & 27 (plan 48) & Critical limb ischaemia & $3 \times 4.0 \mathrm{mg}$ AMG0001, $\mathrm{n}=21$ & $n=6$ \\
\hline Shigematsu 2010 & 40 (plan 46) & Critical limb ischaemia & $2 \times 4.0 \mathrm{mg}$ AMG0001, $\mathrm{n}=27$ & $n=13$ \\
\hline \multirow[t]{2}{*}{ Kibbe 2016} & 52 & Critical limb ischaemia & $2 \times 4.0 \mathrm{mg}$ VM202 (HGF-X7), $\mathrm{n}=21$ & $\mathrm{n}=11$ \\
\hline & & & $4 \times 4.0 \mathrm{mg}$ VM202 (HGF-X7), $\mathrm{n}=20$ & \\
\hline \multirow[t]{3}{*}{ VM202-China $a$} & 200 & Critical limb ischaemia & $3 \times 4.0 \mathrm{mg}$ NL003 (pCK-HGF-X7), $\mathrm{n}=?$ & $\mathrm{n}=?$ \\
\hline & & & $3 \times 6.0 \mathrm{mg}$ NL003 (pCK-HGF-X7), $\mathrm{n}=?$ & \\
\hline & & & $3 \times 8.0 \mathrm{mg}$ NL003 (pCK-HGF-X7), $\mathrm{n}=$ ? & \\
\hline
\end{tabular}

\section{Vascular endothelial growth factor}

\begin{tabular}{|c|c|c|c|c|}
\hline Rauh $1999 a$ & 13 & Critical limb ischaemia & VEGF-C, $\mathrm{n}=?$ & $\mathrm{n}=?$ \\
\hline \multirow[t]{2}{*}{ Makinen 2002} & \multirow[t]{2}{*}{54 (plan 60) } & \multirow{2}{*}{$\begin{array}{l}\text { Intermittent claudicationc } \\
\text { Critical limb ischaemia }\end{array}$} & VEGF-Ad $\left(2 \times 10^{10}\right.$ VEGF165), $\mathrm{n}=18$ & \multirow[t]{2}{*}{$\mathrm{n}=19$} \\
\hline & & & VEGF-P/L $(2 \times 2.0 \mathrm{mg}$ VEGF165), $\mathrm{n}=17$ & \\
\hline \multirow[t]{2}{*}{ RAVE } & \multirow[t]{2}{*}{105 (plan 105) } & \multirow[t]{2}{*}{ Intermittent claudication } & $4 \times 10^{9}$ PU AdVEGF121, $\mathrm{n}=32$ & \multirow[t]{2}{*}{$n=33$} \\
\hline & & & $4 \times 10^{10}$ PU AdVEGF121, $n=40$ & \\
\hline Kusumanto 2006 & 54 & Critical limb ischaemia & $2 \times 2.0 \mathrm{mg}$ phVEGF165, $\mathrm{n}=27$ & $n=27$ \\
\hline Deev 2015 & 100 & $\begin{array}{l}\text { Intermittent claudicationc, } \\
\text { Critical limb ischaemia }\end{array}$ & $2 \times 1.2 \mathrm{mg}$ pCMV-VEGF165, $\mathrm{n}=75$ & $\mathrm{n}=25^{\mathrm{d}}$ \\
\hline NCT00080392 a & 10 & Intermittent claudication & VEGF-A, $n=?$ & $\mathrm{n}=?$ \\
\hline NCT00304837a & $?$ & Critical limb ischaemia & VEGF-C, $\mathrm{n}=?$ & $\mathrm{n}=?$ \\
\hline
\end{tabular}

a Unpublished trial.

b2 participants not randomised.

cMainly.

dNo therapy. 


\begin{tabular}{|c|c|c|c|c|c|c|c|}
\hline Trial & Amputation & Death & $\begin{array}{l}\text { Adverse events/serious adverse } \\
\text { events (SAE) }\end{array}$ & Walking & $\begin{array}{l}\text { Haemody- } \\
\text { namic para- } \\
\text { meters }\end{array}$ & Ulceration & Rest pain \\
\hline \multicolumn{8}{|c|}{ Fibroblast growth factor } \\
\hline Lazarous 2000 & NR & NR & Data for single events & Improvement & $\begin{array}{l}\text { Plethysmog- } \\
\text { raphy }\end{array}$ & - & - \\
\hline Cooper 2001 & NR & All & Data for single events & PWT, COT & $A B I^{*}$ & - & - \\
\hline TRAFFIC & NR & All & Data for single events & PWT, COT & $A B I^{*}$ & - & - \\
\hline TALISMAN-201 & Major, Any & All & Aggregate & - & ABI, TBI & Complete healing & VAS \\
\hline TALISMAN-202 & \multicolumn{7}{|c|}{ Unpublished trial } \\
\hline TALISMAN-211 & \multicolumn{7}{|c|}{ Unpublished trial } \\
\hline TAMARIS & Major & All & Aggregate & - & NR & NR & NR \\
\hline Matyas 2005 & Not defined & All & Data for single eventsa & - & $A B I$ & Complete healing & VAS \\
\hline & & & & & & & Improvement \\
\hline \multicolumn{8}{|c|}{ Hepatocyte growth factors } \\
\hline \multirow[t]{2}{*}{ HGF-STAT } & Alla & All & Aggregate (SAEs) & - & $\left.\mathrm{AB}\right|^{\mathrm{a}},\left.\mathrm{TB}\right|^{\mathrm{a}}$ & Area & \multirow[t]{2}{*}{$\begin{array}{l}\text { Improvemen- } \\
\text { ta }\end{array}$} \\
\hline & & & & & & Complete healinga & \\
\hline \multirow[t]{2}{*}{ HGF-0205 } & Major & All & Aggregate & - & $A B I, T B I$ & Area & \multirow[t]{2}{*}{ VAS } \\
\hline & & & & & & Complete healing & \\
\hline \multirow[t]{2}{*}{ Shigematsu 2010} & Major, Any & NR & Aggregate & - & $\left.A B\right|^{a}$ & Improvement & \multirow[t]{2}{*}{ Improvement } \\
\hline & & & & & & Complete healing & \\
\hline Kibbe 2016 & Major, Any & All & Aggregate (SAEs) & - & $\mathrm{ABI}$ & $\begin{array}{l}\text { Improvement } \\
\text { Complete healing }\end{array}$ & $\begin{array}{l}\text { VAS Improve- } \\
\text { ment }\end{array}$ \\
\hline
\end{tabular}




\begin{tabular}{|c|c|c|c|c|c|c|c|}
\hline VM202-China & \multicolumn{7}{|c|}{ Unpublished trial } \\
\hline \multicolumn{8}{|c|}{ Vascular endothelial growth factor } \\
\hline Rauh 1999 & \multicolumn{7}{|c|}{ Unpublished trial } \\
\hline Makinen 2002 & Major & All & Data for single events & - & $A B I$ & Complete healing & Improvement \\
\hline RAVE & Not defined & All & Data for single events & PWT, COT & $A B I^{a}$ & - & - \\
\hline Kusumanto 2006 & Major & All & Data for single events & - & Improvement & Improvement & Improvement \\
\hline Deev 2015 & Not defined & All & Data for single events & PWD & $A B I$ & - & - \\
\hline NCT00080392 & \multicolumn{7}{|c|}{ Unpublished trial } \\
\hline NCT00304837 & \multicolumn{7}{|c|}{ Unpublished trial } \\
\hline
\end{tabular}

ABI: ankle brachial index; COT: claudication onset time; NR: not reported; PWD: peak walking distance; PWT: peak walking time; TBI: toe brachial index; VAS: visual analogue scale. aData not appropriate for meta-analyses. 


\section{APPENDICES}

\section{Appendix 1. CENTRAL search strategy}

\begin{tabular}{llc}
\hline$\# 1$ & MESH DESCRIPTOR Arteriosclerosis & 867 \\
\hline$\# 2$ & MESH DESCRIPTOR Arteriolosclerosis EXPLODE ALL TREES & 0 \\
\hline$\# 3$ & MESH DESCRIPTOR Arteriosclerosis Obliterans & 70 \\
\hline$\# 4$ & MESH DESCRIPTOR Atherosclerosis & 586 \\
\hline$\# 5$ & MESH DESCRIPTOR Arterial Occlusive Diseases & 714 \\
\hline$\# 6$ & MESH DESCRIPTOR Intermittent Claudication & 697 \\
\hline$\# 7$ & MESH DESCRIPTOR Ischemia & 771 \\
\hline$\# 8$ & MESH DESCRIPTOR Peripheral Vascular Diseases EXPLODE ALL TREES & 2166 \\
\hline
\end{tabular}

\begin{tabular}{|c|c|c|}
\hline \#9 & (atherosclero* or arteriosclero* or PVD or PAOD or PAD ):TI,AB,KY & 8565 \\
\hline$\# 10$ & 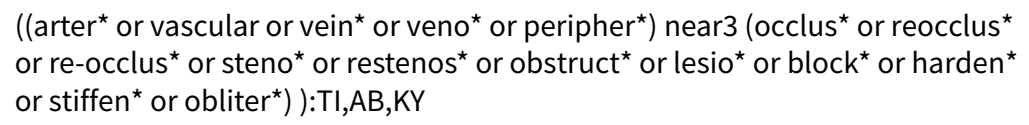 & 7283 \\
\hline$\# 11$ & (peripheral near3 dis*):TI,AB,KY & 3129 \\
\hline$\# 12$ & (claudic $^{*}$ or IC):TI,AB, KY & 2845 \\
\hline$\# 13$ & (isch* or CLI):TI,AB,KY & 21827 \\
\hline \#14 & arteriopathic or leriche ${ }^{\star}: \mathrm{TI}, \mathrm{AB}, \mathrm{KY}$ & 56 \\
\hline \#15 & dysvascular*:TI,AB,KY & 10 \\
\hline
\end{tabular}

\#16 (leg near3 (occlus ${ }^{\star}$ or reocclus ${ }^{\star}$ or re-occlus ${ }^{\star}$ or steno* or restenos ${ }^{\star}$ or ob- $\quad 87$ struct $^{\star}$ or lesio* or block ${ }^{\star}$ or harden* or stiffen* or obliter ${ }^{\star}$ ) ):TI,AB,KY

\begin{tabular}{|c|c|c|}
\hline \#17 & 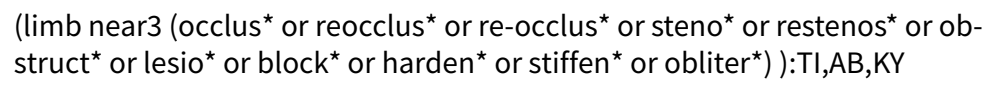 & 126 \\
\hline$\# 18$ & $\begin{array}{l}\left(\left(\text { lower near3 extrem }^{\star}\right) \text { near3 } \text { (occlus }^{\star} \text { or reocclus* or re-occlus* or steno* }\right. \\
\text { or restenos }^{\star} \text { or obstruct* or lesio* or block }{ }^{\star} \text { or harden* or stiffen* or } \\
\left.\left.\text { obliter }^{\star}\right)\right): \mathrm{TI}, \mathrm{AB}, \mathrm{KY}\end{array}$ & 74 \\
\hline \#19 & MESH DESCRIPTOR Leg EXPLODE ALL TREES WITH QUALIFIERS BS & 1096 \\
\hline$\# 20$ & MESH DESCRIPTOR Iliac Artery & 141 \\
\hline \#21 & MESH DESCRIPTOR Popliteal Artery & 267 \\
\hline \#22 & MESH DESCRIPTOR Femoral Artery & 790 \\
\hline \#23 & MESH DESCRIPTOR Tibial Arteries & 32 \\
\hline
\end{tabular}


(Continued)

\#24 (((femor ${ }^{\star}$ or iliac or popliteal or fempop* or crural or poplite* or infrapopliteal or inguinal or femdist* ${ }^{\star}$ or inguinal or infrainquinal or tibial) near3 (occlus* or reocclus* or re-occlus ${ }^{\star}$ or steno* or restenos* or obstruct* or lesio* or block* or harden* or stiffen ${ }^{\star}$ or obliter $\left.{ }^{\star}\right)$ )):TI,AB,KY

\begin{tabular}{|c|c|c|}
\hline \#25 & $\begin{array}{l}\text { \#1 OR \#2 OR \#3 OR \#4 OR \#5 OR \#6 OR \#7 OR \#8 OR \#9 OR \#10 OR \#11 OR \#12 } \\
\text { OR \#13 OR \#14 OR \#15 OR \#16 OR \#17 OR \#18 OR \#19 OR \#20 OR \#21 OR \#22 OR } \\
\text { \#23 or \#24 }\end{array}$ & 40732 \\
\hline \#26 & MESH DESCRIPTOR Neovascularization, Physiologic EXPLODE ALL TREES & 147 \\
\hline$\# 27$ & MESH DESCRIPTOR Angiogenic Proteins EXPLODE ALL TREES & 827 \\
\hline \#28 & MESH DESCRIPTOR Angiogenesis Inducing Agents EXPLODE ALL TREES & 39 \\
\hline$\# 29$ & MESH DESCRIPTOR Fibroblast Growth Factors EXPLODE ALL TREES & 247 \\
\hline \#30 & MESH DESCRIPTOR Hepatocyte Growth Factor EXPLODE ALL TREES & 58 \\
\hline \#31 & MESH DESCRIPTOR Platelet-Derived Growth Factor EXPLODE ALL TREES & 118 \\
\hline \#32 & MESH DESCRIPTOR Erythropoietin EXPLODE ALL TREES & 1435 \\
\hline \#33 & angiogen ${ }^{\star}: \mathrm{TI}, \mathrm{AB}, \mathrm{KY}$ & 1901 \\
\hline \#34 & neovascular*:TI,AB,KY & 1757 \\
\hline \#35 & (growth factor):TI,AB,KY & 7561 \\
\hline \#36 & VEGF $^{\star}: \mathrm{TI}, \mathrm{AB}, \mathrm{KY}$ & 1615 \\
\hline$\# 37$ & $\mathrm{FGF}^{\star}: \mathrm{TI}, \mathrm{AB}, \mathrm{KY}$ & 389 \\
\hline \#38 & $\mathrm{HGF}^{\star}: \mathrm{TI}, \mathrm{AB}, \mathrm{KY}$ & 154 \\
\hline \#39 & $\mathrm{PDGF}^{\star}: \mathrm{TI}, \mathrm{AB}, \mathrm{KY}$ & 258 \\
\hline \#40 & PD-GF*:TI,AB,KY & 3 \\
\hline \#41 & angiopoietin ${ }^{\star}: \mathrm{TI}, \mathrm{AB}, \mathrm{KY}$ & 111 \\
\hline \#42 & Erythropoietin*:TI,AB,KY & 2923 \\
\hline \#43 & EPO:TI,AB,KY & 894 \\
\hline$\# 44$ & (colony stimulating factor ${ }^{\star}$ ):TI,AB, KY & 3146 \\
\hline \#45 & $\mathrm{GMCSF}^{\star}: \mathrm{TI}, \mathrm{AB}, \mathrm{KY}$ & 51 \\
\hline \#46 & $\mathrm{GM}-\mathrm{CSF}^{\star}: \mathrm{TI}, \mathrm{AB}, \mathrm{KY}$ & 1076 \\
\hline \#47 & (Del or SDF or HIF or PGC):TI,AB,KY & 1017 \\
\hline$\# 48$ & $\begin{array}{l}\# 26 \text { OR \#27 OR \#28 OR \#29 OR\#30 OR \#31 OR\#32 OR \#33 OR \#34 OR \#35 OR \#36 } \\
\text { OR \#37 OR \#38 OR \#39 OR \#40 OR \#41 OR \#42 OR\#43 OR \#44 OR \#45 OR \#46 OR } \\
\text { \#47 }\end{array}$ & 17481 \\
\hline
\end{tabular}




\section{CONTRIBUTIONS OF AUTHORS}

VG: selected and assessed studies, extracted data and performed analyses; conceived, wrote and edited the review (guarantor for the review).

MB: provided clinical advice, contributed to the text.

AK: provided advice on methodological issues and contributed to the text.

$\mathrm{AH}$ : selected and assessed studies, checked data extraction and analyses; coordinated the review process, performed part of the writing/ editing of the review.

\section{DECLARATIONS OF INTEREST}

VG: institution received funding from the German Federal Ministry of Education and Research (research grant 01KG1411) to conduct the review.

MB: institution received funding from the German Federal Ministry of Education and Research (research grant 01KG1411) to conduct the review.

AK: institution received funding from the German Federal Ministry of Education and Research (research grant 01KG1411) to conduct the review.

$\mathrm{AH}$ : institution received funding from the German Federal Ministry of Education and Research (research grant 01KG1411) to conduct the review.

\section{SOURCES OF SUPPORT}

\section{Internal sources}

- No sources of support supplied

\section{External sources}

- German Federal Ministry of Education and Research, Germany.

The authors' Institution received funding from the German Federal Ministry of Education and Research (research grant 01KG1411) to conduct the review

- Chief Scientist Office, Scottish Government Health Directorates, The Scottish Government, UK.

The Cochrane Vascular editorial base is supported by the Chief Scientist Office.

\section{DIFFERENCES BETWEEN PROTOCOLANDREVIEW}

\section{A. 'Types of outcome measures'}

We changed one primary outcome (level of pain in the protocol) to a secondary outcome in the review (renamed as rest pain), and we changed one secondary outcome (severe complications/adverse events) to a primary outcome. We judged severe complications/adverse events to be more important as an outcome for decision making than rest pain. Moreover, only a few trials measured pain, sometimes only in a subgroup of participants. Therefore, these measurements cannot reflect changes in pain and may be misleading as a primary outcome for decision-making.

We present the types of outcome measures as reported in the protocol of this review below.

\section{Primary outcomes}

1. Limb amputation (rate)

2. Level of pain (questionnaire)

3. Death (rate)

\section{Secondary outcomes}

1. Severe complications (e.g. severe inflammation, limb oedema, neoplasia)

2. Pain-free walking time/distance

3. Haemodynamic measures of blood flow (e.g. ankle brachial index, duplex scanning or angiography)

4. Level of ulceration (\% surface area) 


\section{B. 'Data synthesis'}

We adjusted the text, as we found only one trial at low risk of bias and with no other comparators apart from placebo or no intervention. We pooled the results of all trials only in sensitivity meta-analyses.

We present the 'Data synthesis' section of the review protocol below.

"We will perform data synthesis using Cochrane's statistical software, RevMan 2014, according to guidelines of the Cochrane PVD Group. We will use a fixed-effect model if all trials in the analysis are sufficiently similar and there is a reasonable assumption that the underlying effect size is the same for all of them. If a reasonable assumption that the underlying effect size is not the same for all of the trials, we will use a random-effects model. If pooling is not possible, we will undertake a narrative synthesis of the studies results. We will perform separate analysis for different comparators (no intervention or placebo, other interventions not based on growth factor's action)."

\section{INDEX TERMS}

\section{Medical Subject Headings (MeSH)}

Amputation [statistics \& numerical data]; Fibroblast Growth Factors [adverse effects] [^therapeutic use]; Hepatocyte Growth Factor [adverse effects] [ ${ }^{\star}$ therapeutic use]; Intermittent Claudication [ ${ }^{\star}$ drug therapy] [mortality]; Leg [blood supply] [surgery]; Leg Ulcer [drug therapy]; Peripheral Arterial Disease [ ${ }^{\star}$ drug therapy] [mortality]; Randomized Controlled Trials as Topic; Vascular Endothelial Growth Factor A [adverse effects] [ ${ }^{\star}$ therapeutic use]

\section{MeSH check words}

Humans 